\title{
Abordagens moleculares para detectar cianobactérias e seus genótipos produtores de microcistinas presentes nas represas Billings e Guarapiranga, São Paulo, Brasil
}

\section{ADRI ANA STURI ON LORENZI}

\begin{abstract}
Dissertação apresentada ao Centro de Energia Nuclear na Agricultura, Universidade de São Paulo, para obtenção do título de Mestre em Ciências, Área de Concentração: Energia Nuclear na Agricultura.
\end{abstract}

PI R A C I C A B A

Estado de São Paulo - Brasil

Fevereiro - 2004 


\title{
Abordagens moleculares para detectar cianobactérias e seus genótipos produtores de microcistinas presentes nas represas Billings e Guarapiranga, São Paulo, Brasil
}

\section{ADRI ANA STURI ON LORENZI}

Engenheira Agrônoma

Orientadora: Dra. MARLI DE FÁTI MA FIORE

Dissertação apresentada ao Centro de Energia Nuclear na Agricultura, Universidade de São Paulo, para obtenção do título de Mestre em Ciências, Área de Concentração: Energia Nuclear na Agricultura.

\author{
PI R A CI CABA \\ Estado de São Paulo - Brasil \\ Fevereiro - 2004
}


Dados Internacionais de Catalogação na Publicação (CIP) Seção Técnica de Biblioteca - CENA/USP

Lorenzi, Adriana Sturion

Abordagens moleculares para detectar cianobactérias e seus genótipos produtores de microcistinas presentes nas represas Billings e Guarapiranga, São Paulo, Brasil / Adriana Sturion Lorenzi. - - Piracicaba, 2004.

92p. : il.

Dissertação (mestrado) - - Centro de Energia Nuclear na Agricultura, 2004.

1. Clonagem 2. Monitoramento ambiental 3. PCR 4. Peptídeos cíclicos 5. Polimorfismo 6. RNA ribossômico I. Título

CDU 582.232:577.21 
Aos meus pais, Laerte e Dorotéa, por todo o amor, apoio e dedicação

em todos os momentos da minha

vida, ofereço

"A Deus, meu maior exemplo de amor, pela presença constante em minha vida"

Ao meu irmão André, pelo carinho e incentivo, dedico 


\section{AGRADECI MENTOS}

À Dra. Marli de Fátima Fiore, pela orientação, confiança, incentivo constante e amizade,

Ao Prof. Dr. Marcio Rodrigues Lambais, por ter disponibilizado seu laboratório, sugestões, idéias e atenção, minha gratidão,

À Dra. Siu Mui Tsai por todo o apoio fornecido,

À Dra. Célia Leite Sant'Anna e Dra. Maria Teresa de Paiva Azevedo, pelas contribuições indispensáveis,

Ao Dr. Brett A. Neilan pelo desenho dos oligonucleotídeos iniciadores,

Aos amigos e colegas do Laboratório de Biologia Celular e Molecular, em especial a Ana Luiza, Camila, Carol, Cris, Diego F., Diego, Edenilson, Karla, Tânia, Vitor e Yasmin, pelo apoio e agradável convívio,

Aos amigos e colegas do Laboratório de Microbiologia Molecular (ESALQ/USP), Adriana, Agustín, Beth, Daniele, Denise, Denise Mescolotti, Felipe, Fernando Baldesin, Juliano, Leandra, Renato, Ricardo, Robinson, Simão e Suzel, pelo constante auxílio e amizade,

Aos meus tios(as) e primos(as), pela feliz união familiar e pelo crescimento pessoal que sempre me proporcionaram,

À CETESB, pela colaboração indispensável na coleta de água das represas,

À FAPESP, pela bolsa de estudo e recursos financeiros concedidos. 


\section{SUMÁRIO}

Página

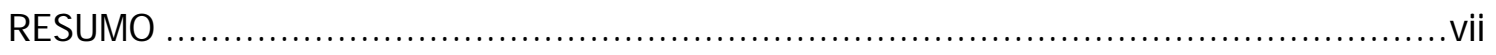

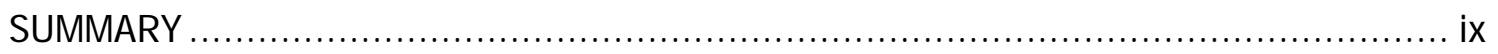

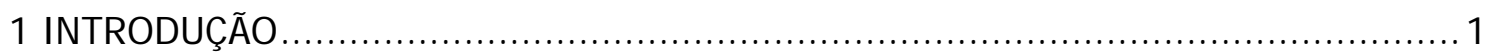

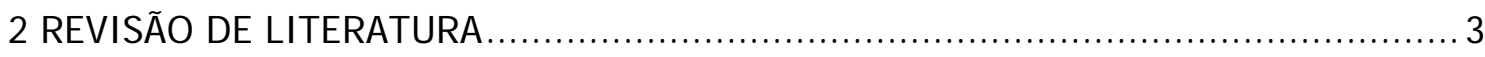

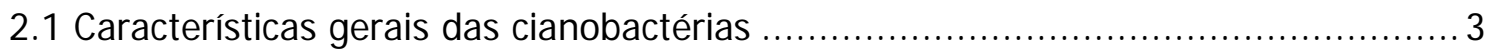

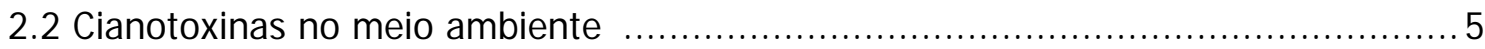

2.3 Métodos para detecção de cianobactérias e suas toxinas em águas..................... 8

2.3.1 Subunidade 16S do RNA ribossômico (rRNA 16S) ................................ 13

2.3.2 Região do espaço intergênico da ficocianina (PC-IGS) ........................... 15

2.3.3 Domínio $N$-metiltransferase do gene mcyA ...................................... 16

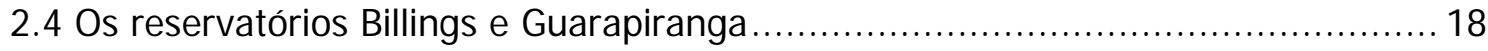

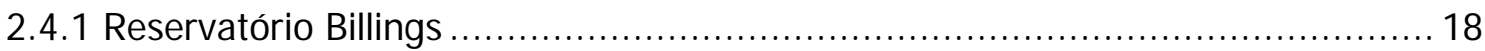

2.4.2 Reservatório Guarapiranga ................................................. 20

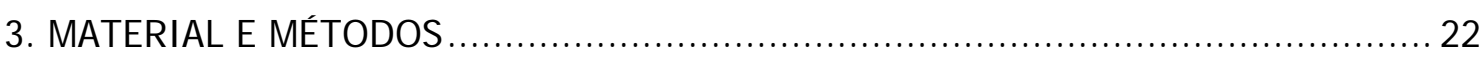

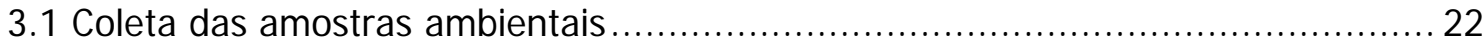

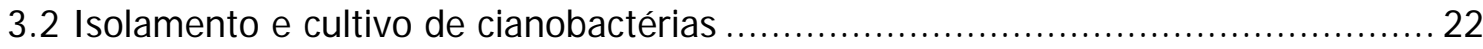

3.3 Extração de DNA genômico de culturas puras de cianobactérias ....................... 30

3.4 Extração de DNA genômico de amostras ambientais de água......................... 30

3.5 Análise da biodiversidade de cianobactérias por meio de DGGE ..................... 31

3.5.1 Amplificação do gene que codifica para o rRNA 16S ................................ 31

3.5.2 Utilização de DGGE com amplicons do gene de rRNA 16S .......................... 32

3.5.3 Excisão dos amplicons a partir do gel de poliacrilamida ............................ 33 
3.5.4 Seqüenciamento de amplicons do gene de rRNA 16S …............................. 33

3.5.5 Processamento e análise filogenética das seqüências ..................................... 34

3.6 Análise da biodiversidade de cianobactérias por meio da construção de mini-

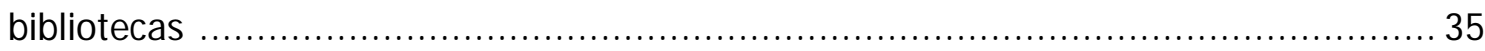

3.6.1 Mini-biblioteca de amplicons do gene de rRNA 16S ..................................... 35

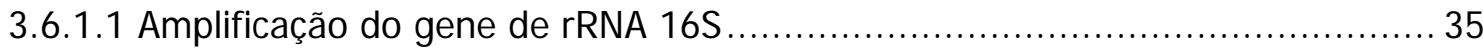

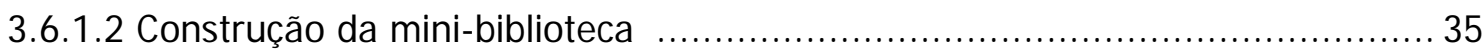

3.6.2 Mini-biblioteca de amplicons da região do PC-IGS ..................................... 39

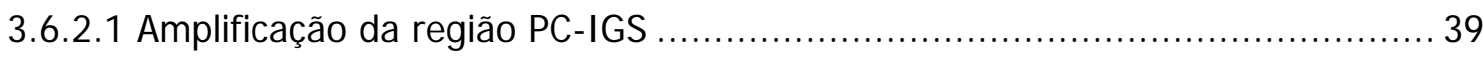

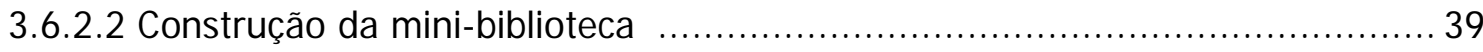

3.7 Detecção do domínio $\mathrm{N}$-metiltransferase do gene mcyA ..................................40

3.7.1 Amplificação do domínio $\mathrm{N}$-metiltransferase do gene mcyA ............................ 40

3.7.2 Seqüenciamento do fragmento do domínio NMT do gene mcyA ...................... 41

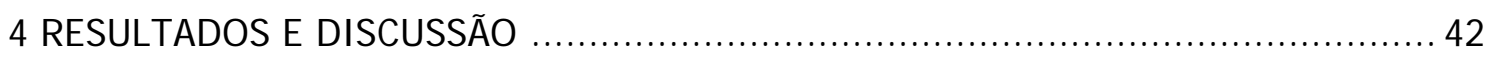

4.1 Isolamento e cultivo de cianobactérias ..................................................... 42

4.2 Extração de DNA genômico de culturas puras de cianobactérias e de amostras

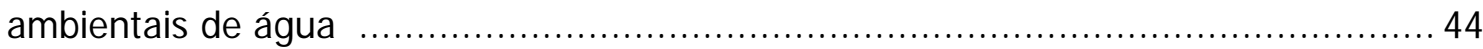

4.3 Análise da biodiversidade de cianobactérias por meio de DGGE ...................... 44

4.4 Análise da biodiversidade de cianobactérias por meio da construção de mini-

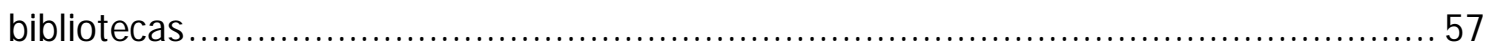

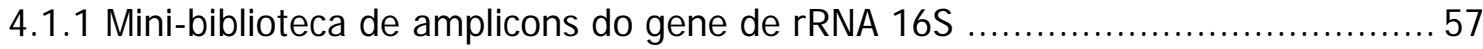

4.1.2 Mini-biblioteca de amplicons da região do PC-IGS ....................................... 60

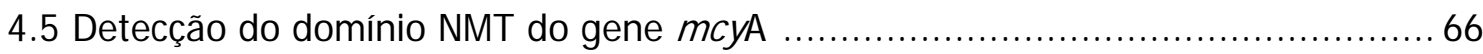

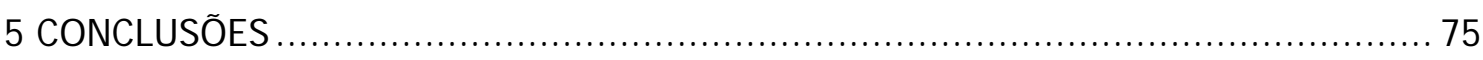

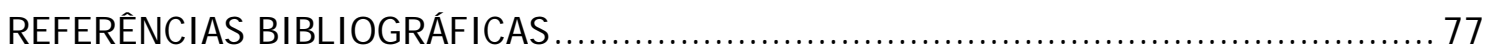




\title{
Abordagens moleculares para detectar cianobactérias e seus genótipos produtores de microcistinas presentes nas represas Billings e Guarapiranga, São Paulo, Brasil
}

\author{
Autora: ADRIANA STURION LORENZI \\ Orientadora: Dra. MARLI DE FÁTIMA FIORE
}

RESUMO

As florações de cianobactérias em reservatórios de águas utilizadas para consumo humano são freqüentes hoje em dia e normalmente são atribuídas à crescente eutrofização destas águas. Em anos recentes o aparecimento de linhagens de cianobactérias produtoras de toxinas tem preocupado bastante os responsáveis pelo monitoramento da qualidade das águas, uma vez que estas toxinas representam risco para a saúde pública. A detecção precoce da presença de linhagens tóxicas nesses reservatórios é essencial para que ações corretivas de controle das florações tenham sucesso. No presente trabalho, a diversidade de cianobactérias presentes em alguns locais das represas Billings e Guarapiranga foi avaliada utilizando a técnica de DGGE (eletroforese em gel de poliacrilamida com gradiente desnaturante) e/ou construções de mini-bibliotecas de amplicons do gene de rRNA $16 \mathrm{~S}$ e da região do espaço intergênico da ficocianina (PC-IGS). A DGGE, utilizando os iniciadores CYA359F/CYA781R específicos para o gene de rRNA 16S de cianobactérias, mostraram que estes organismos estavam presentes nas onze amostras de água analisadas. Microcystis aeruginosa (94-97\% de identidades), Geitlerinema (89\% de identidade) e Synechococcus (89\% de identidade) puderam ser identificadas. A mini-biblioteca construída com os amplicons de rRNA 16S obtidos usando os iniciadores 27F1/1494Rc produziu seqüências de outro grupo de bactéria (Actinobacteria), indicando a 
inespecificidade desses iniciadores. Entretanto, na mini-biblioteca construída com os amplicons de PC-IGS obtidos usando os iniciadores PCBF/PCaR, somente seqüências de cianobactérias foram geradas. Nessa mini-biblioteca foram identificadas várias linhagens de Microcystis aeruginosa (98-100\% de identidades) e também de Anabaena (89\% de identidade). Esses dois gêneros de cianobactérias conhecidos por produzirem microcistinas, foram detectados na amostra de água que continha alta concentração desta toxina $(23,49 \mu \mathrm{g} / \mathrm{L})$.

Os oligonucleotídeos iniciadores OMETF/OMETR foram desenhados para amplificar uma região pequena e variável do domínio da $\mathrm{N}$-metiltransferase do gene mcyA e foram testados em treze espécies de cianobactérias isoladas das represas Billings e Guarapiranga. Seqüências geradas por esses iniciadores foram isoladas, clonadas e sequenciadas com sucesso em duas espécies controle ( $M$. aeruginosa NPJB1 e M. panniformis SPC702) e em dois isolados das represas (M. aeruginosa SPC777 e $M$. protocystis SPC697). A amplificação dessa região do mcyA a partir dos DNAs dos isolados de cianobactérias permitiu identificar linhagens do gênero Microcystis potencialmente produtoras da toxina microcistina. Essa técnica uma vez bem estabelecida para organismos isolados, poderá proporcionar base suficiente para uma melhor deteç̧ão de comunidades aquáticas de cianobactérias potencialmente produtoras de microcistinas em ambientes naturais. 


\title{
Molecular approaches to detect cyanobacteria and their microcystins producing genotypes in Billings and Guarapiranga reservoirs, São Paulo, Brazil
}

\author{
Author: ADRIANA STURION LORENZI \\ Adviser: Dr. MARLI DE FÁTIMA FIORE
}

\section{SUMMARY}

Cyanobacterial blooms in water reservoirs used for human consumption are frequent nowadays and are usually attributed to the increasing water eutrophization. In recent years, the appearance of toxin-producing cyanobacterial strains has concerned managers of water quality since these toxins represent a public health risk. Early detection of the presence of toxic strains in these reservoirs is essential for the success of bloom control corrective actions. In the present work, cyanobacterial diversity was evaluated in several sites of Billings and Guarapiranga reservoirs using DGGE (denaturing gradient gel eletrophoresis) and/or mini-library constructions of both $16 \mathrm{~S}$ rRNA gene and phycocyanin intergenic spacer (PC-IGS) region amplicons. The DGGE, using CYA359F/CYA781R primers, specific for cyanobacterial 16S rRNA gene, showed the presence of these organisms in the eleven water samples analyzed. Microcystis aeruginosa (identities of 94-97\%), Geitlerinema (identity of 89\%) and Synechococcus (identity of $89 \%$ ) were identified. The mini-library constructed with $16 \mathrm{~S}$ rRNA amplicons obtained using 27F1/1494Rc primers produced sequences of another group of bacteria (Actinobacteria), indicating the unespecificity of these primers. However, the minilibrary constructed with PC-IGS amplicons obtained using PCBF/PCaR primers, generated cyanobacterial sequences only. In this mini-library several Microcystis aeruginosa strains (identities of $98-100 \%$ ) and Anabaena (identity of $89 \%$ ) were 
identified. These two cyanobacterial genera known to produce microcystins were detected in a water sample containing a high concentration of this toxin $(23.49 \mu \mathrm{g} / \mathrm{L})$.

The OMETF/OMETR primers were designed to amplify a small and variable region of the $N$-methyltransferase domain of mcyA gene and were tested in thirteen cyanobacterial strains isolated from Billings and Guarapiranga reservoirs. Sequences generated with these primers were successfully isolated, cloned and sequenced in two control species (M. aeruginosa NPJB1 and M. panniformis SPC702) and in two isolates from these reservoirs ( $M$. aeruginosa SPC777 and $M$. protocystis SPC697). The amplification of this region of $m c y A$ using cultured cyanobacteria DNAs allowed the identification of Microcystis strains with the potential to produce microcystin toxin. This technique, after it is well established for cultured organisms, will provide a basis for better detection of potential microcystin-producing cyanobacterial aquatic communities in natural environments. 


\section{I NTRODUÇÃO}

A diminuição da qualidade da água dos reservatórios predominantemente utilizada para o abastecimento público, irrigação e recreação é um fato bastante preocupante. 0 aumento da eutrofização desses sistemas pelo enriquecimento de nutrientes, especialmente fósforo e nitrogênio, tem favorecido a proliferação e, em certos casos a predominância, de cianobactérias produtoras de toxinas, acarretando graves conseqüências para a saúde de animais e humanos, além da elevação dos custos no tratamento de águas destinadas ao abastecimento, devido à necessidade da remoção de material particulado, gosto e odores indesejáveis.

Várias espécies de cianobactérias que formam florações em ambientes aquáticos produzem uma grande variedade de compostos tóxicos, incluindo neurotoxinas e hepatotoxinas. As microcistinas, caracterizadas como hepatotoxinas, têm sido as mais estudadas por causarem problemas no mundo todo. Registros de intoxicações em populações humanas devido à exposição às toxinas de cianobactérias têm ocorrido em muitos países (África do Sul, Austrália, Brasil, China, Inglaterra, Suécia). Entretanto, o primeiro registro mundial de envenenamento fatal em humanos ocorreu no Brasil, em 1996, numa clínica de hemodiálise de Caruaru (PE), onde mais de 60 pacientes vieram a falecer devido à contaminação da água desta clínica com toxinas de cianobactérias.

Atualmente, os corpos d'água são monitorados para a presença de cianobactérias através de contagem de células e identificação usando microscopia ótica, uma prática bastante trabalhosa. Entretanto, a produção de toxina é específica ao nível de linhagens e não pode ser diagnosticada somente através da identificação da espécie, sendo que linhagens tóxicas e não tóxicas podem estar presentes numa mesma floração. Assim, testes biológicos, bioquímicos ou químicos são necessários para detectar populações de cianobactérias produtoras de toxinas. A deteç̧ão precoce 
de populações tóxicas é desejável para que ações corretivas de controle de florações tenham sucesso. Uma alternativa é a utilização de técnicas de biologia molecular para precocemente identificar populações produtoras de toxinas presentes em ambientes naturais. A técnica da reação em cadeia da polimerase (PCR), utilizando oligonucleotídeos iniciadores específicos para seqüências de genes envolvidos com a produção de toxinas, tem se mostrado altamente sensível para detectar linhagens de cianobactérias produtoras de microcistinas. Atualmente, vários iniciadores capazes de identificar culturas puras e florações produtoras de microcistinas estão descritos na literatura. Essa tecnologia baseada em ácidos nucléicos, uma vez bem estabelecida para organismos isolados e amostras ambientais, pode proporcionar base suficiente para aplicação em ambientes aquáticos. Dessa forma, kits poderão ser desenvolvidos e convenientemente usados para detectar precocemente as florações tóxicas e quantificar suas toxinas, o que pode facilitar o monitoramento de ambientes aquáticos, minimizando os riscos para a saúde pública.

O presente estudo objetivou avaliar a biodiversidade de cianobactérias em alguns locais das represas Billings e Guarapiranga, São Paulo, Brasil, utilizando métodos moleculares e também desenvolver e testar um conjunto de oligonucleotídeos iniciadores capaz de detectar linhagens e florações de cianobactérias potencialmente produtoras da toxina microcistina. 


\section{REVISÃO DE LITERATURA}

\subsection{Características gerais das cianobactérias}

As cianobactérias constituem um grande e filogeneticamente coerente grupo dentro do domínio Bacteria capazes de realizar fotossíntese com liberação de $\mathrm{O}_{2}$, sendo autotrófico o modo nutricional dominante (Castenholz \& Waterbury, 1989). Seus processos vitais requerem somente água, dióxido de carbono, substâncias inorgânicas e luz. Entretanto, apesar da sua natureza tipicamente fotossintética aeróbica, algumas espécies podem crescer no escuro na presença de certos substratos orgânicos (heterotróficos facultativos) (Smith, 1983; Stal \& Moezelaar, 1997) e outras, sob condições anaeróbicas, utilizam o sulfeto como doador de elétrons para a fotossíntese (Cohen et al., 1986).

Algumas espécies de cianobactérias são também capazes de fixar o nitrogênio atmosférico apresentando assim a forma nutricional mais simples de todos os microrganismos (Bergman et al., 1997; Fay, 1992). Essas espécies contribuem globalmente para a fertilidade dos solos e águas (Rai, 1990).

As cianobactérias exibem uma grande variedade de formas e arranjos, de cocos unicelulares à bacilos e mesmo filamentosas e filamentosas ramificadas multicelulares. Não possuem flagelos, mas as espécies filamentosas geralmente possuem movimento deslizante e podem migrar através de superfícies úmidas. Apesar de serem organismos de dimensões microscópicas, o tamanho de suas células varia entre 1 a $100 \mu \mathrm{m}$, podem, muitas vezes, serem visualizadas a olho nu nos locais de ocorrência, uma vez que formam densos tapetes ou fitoplâncton contendo também algumas outras espécies microbianas.

A capacidade de crescimento nos mais diferentes meios é uma das características marcantes das cianobactérias. Esses microrganismos podem ser encontrados em todos os tipos de ecossistemas bem iluminados (exceto em ambientes 
com pH muito baixo), sendo que algumas espécies são capazes de sobreviver em condições ambientais extremas, tais como areia e rochas de desertos, águas termais ("hot springs") e lagos do Ártico e Antártica (Castenholz, 1973; Dor \& Danin, 1996; Skulberg, 1995). Estão, portanto, entre os organismos pioneiros na Terra, sendo provavelmente os primeiros produtores primários de matéria orgânica a liberarem oxigênio elementar na atmosfera primitiva. Juntamente com as algas eucarióticas, compreendem a maior parte da biomassa do mundo (Cannel, 1993; Stanier \& CohenBazire, 1977).

A presença das cianobactérias tem sido observada em ambientes de água doce ou salgada como organismos de vida livre ou ainda em associações com outros organismos, em hábitat terrestres, onde crescem sobre rochas e solos, desempenhando um importante papel nos processos funcionais do ecossistema e na ciclagem de nutrientes. Várias estratégias metabólicas podem explicar 0 sucesso desses microrganismos em lidar com as pressões seletivas dos variados ambientes naturais. Além de realizarem fotossíntese e algumas espécies fixarem o nitrogênio atmosférico, algumas cianobactérias podem ser tolerantes às altas temperaturas, altas irradiações de UV, dessecação, sulfeto livre, e também podem apresentar a habilidade de usar baixas intensidades luminosas. Entretanto, ambientes de água doce são os mais propícios para o crescimento de cianobactérias, pois a maioria das espécies se desenvolvem melhor em águas neutro alcalinas ( $\mathrm{pH} 6-9$ ), temperatura em torno de $25^{\circ} \mathrm{C}$, alta concentração de nutrientes, especialmente nitrogênio e fósforo, e estabilidade da coluna d'água (Mur et al., 1999).

As cianobactérias propiciam também uma extraordinária e ampla faixa de contribuição para a vida dos humanos, apresentando inclusive importância econômica (Mann \& Carr, 1992). Além da produção primária de matéria orgânica e da fixação biológica de nitrogênio por algumas espécies, o uso de cianobactérias na produção de alimentos com valores nutricionais elevados, conversão de energia solar e produtos farmacológicos apresentam um potencial promissor para o futuro (Kreitlow et al., 1999; Skulberg, 1995). Mas embora as propriedades benéficas das cianobactérias sejam de considerável significância, elas também apresentam características detrimentais de 
igual importância. Abundante crescimento de cianobactérias em reservatórios de água cria vários problemas práticos no suprimento de água.

O crescimento intenso das cianobactérias no ambiente aquático, denominado de florações ("blooms"), pode ocorrer quando as condições ambientais são apropriadas e poucas ou apenas uma espécie domina. Esse processo também é observado em reservatórios de águas destinadas ao consumo humano. As cianobactérias que possuem aerótopos (vesículas gasosas) podem formar intensas "massas" ou "espumas" na superfície da água, porém determinadas espécies podem formar florações em diferentes profundidades na coluna d'água. Atualmente, grupos responsáveis pelas análises ambientais têm manifestado grande preocupação em relação a esse fenômeno, atribuindo-o ao aumento da poluição ambiental, e sugerindo um aumento de sua freqüência, com tendência a aumentar ainda mais, num futuro próximo. Condições climáticas e meteorológicas que influenciam a estratificação térmica em ambientes aquáticos possibilitam condições estáveis que favorecem o crescimento intenso, a distribuição espacial e temporal das cianobactérias, associadas às condições eutróficas e hipereutróficas dos ambientes aquáticos (Rapala et al., 1997).

Algumas linhagens de cianobactérias são também capazes de produzir toxinas que constituem um perigo mundial em potencial para a saúde dos animais e humanos. Em águas de abastecimento e recreacionais, as florações são definidas em números de células/mL, quando ultrapassam ca. 20.000 células/mL (Oliver \& Ganf, 1988).

\subsection{Cianotoxinas no meio ambiente}

A diminuição da qualidade da água dos reservatórios predominantemente utilizados para o abastecimento público, irrigação e recreação é um fato bastante preocupante. O aumento da eutrofização desses sistemas pelo enriquecimento de nutrientes, especialmente fósforo e nitrogênio, tem favorecido a proliferação e, em certos casos a predominância, de cianobactérias produtoras de toxinas, acarretando graves conseqüências para a saúde de animais e de humanos (Carmichael, 1988; Skulberg et al., 1984), além da elevação dos custos no tratamento de águas destinadas ao abastecimento, devido à necessidade da remoção de material particulado, das toxinas, do gosto e odores indesejáveis (CETESB, 2003). 
A ocupação desordenada pelo homem ao redor desses corpos d'água tem acelerado o processo de eutrofização, pois em áreas densamente povoadas os efluentes domésticos podem ser responsáveis por cerca de $50 \%$ do aporte de fósforo para rios e lagos. Esgotos domésticos não tratados podem conter acima de $10 \mathrm{mg} / \mathrm{L}$ de fósforo. 0 tratamento secundário oxida matéria orgânica mas não reduz substancialmente o teor de fósforo (Chorus \& Mur, 1999).

Uma grande variedade de metabólitos incomuns são produzidos por cianobactérias, cujas funções naturais são desconhecidas, embora algumas, talvez apenas coincidentemente, são capazes de afetar outra biota. Pesquisa tem sido focalizada primariamente em compostos com impacto sobre os humanos e animais domésticos, tais como toxinas e substâncias farmacológicas úteis. Produtos não tóxicos também têm sido encontrados em cianobactérias, sendo suas propriedades bioquímicas e farmacológicas totalmente desconhecidas.

As toxinas produzidas por cianobactérias são chamadas de cianotoxinas e representam um grupo bastante amplo de toxinas naturais, tanto do ponto de vista químico como toxicológico. Seus mecanismos de toxicidade atualmente descritos e compreendidos são muito diversos e variam de efeitos hepatotóxico, neurotóxico e dermatotóxico à inibição geral de síntese de proteínas (Carmichael, 1988; Sivonen, 1996). Para acessar o perigo específico das cianotoxinas é necessário compreender suas propriedades químicas e físicas, a ocorrência em águas usadas pela população, a regulação da produção e o destino destas no ambiente. Porém, não se sabe ao certo se a produção dessas toxinas é induzida por fatores físico-químicos e/ou está ligada ao processo de crescimento seletivo de cianobactérias ou das florações.

De acordo com Carmichael (1994), as cianotoxinas podem ser classificadas em três grandes grupos de estrutura química: peptídeos cíclicos, alcalóides e lipopolissacarídeos (LPS). Globalmente as toxinas produzidas por cianobactérias mais freqüentes em florações de água doce e salgada são as toxinas de peptídeo cíclico da família das microcistinas e nodularinas, respectivamente. As microcistinas têm sido as mais estudadas por causarem problemas no mundo todo e parecem ser produzidas somente por cianobactérias (Neilan et al., 1999). Sua produção acontece em ambientes 
aquáticos normalmente quando, sob determinadas condições ambientais, ocorre a floração de cianobactérias.

Durante a fase de crescimento das cianobactérias, a produção de toxinas ocorre dentro das células e a maior proporção destas permanecem intracelularmente até a decomposição destes organismos, quando o produto é liberado. Na tentativa de remover microcistinas da água por meio de filtros de carvão ativado, Lambert et al. (1996) demonstraram que o processo de tratamento normal da água, coaglutinação, sedimentação e cloração, foram ineficientes para a eliminação destas toxinas do meio.

Registros de intoxicações em populações humanas devido à exposição às toxinas de cianobactérias têm ocorrido em muitos países (África do Sul, Austrália, Brasil, China, Inglaterra, Suécia) (Azevedo et al., 1994; Falconer, 1994). Estudos realizados na China mostraram correlação positiva entre baixos níveis de microcistinas (50 ng/L) na água consumida pela população humana e o aparecimento de câncer de fígado (Chen et al., 1996). Entretanto, o primeiro registro mundial de envenenamento fatal em humanos ocorreu no Brasil, em 1996, quando a morte de mais de 60 pacientes de uma clínica de hemodiálise de Caruaru (PE) foi atribuída à presença de cianotoxinas na água utilizada para diálise (Jochimsen et al., 1998). Talvez devido a esse fato, apesar da preocupação mundial com a presença de cianotoxinas em reservatórios de abastecimento, somente no Brasil, até o momento, foi criada uma legislação para concentrações admissíveis de cianotoxinas em águas destinadas ao consumo humano. A Portaria 1469 de 29/12/2000 do Ministério da Saúde (Brasil, 2000), que dispõe sobre qualidade de água para consumo humano, contempla a problemática das cianobactérias exigindo seu monitoramento nas tomadas d'água das captações e análise de suas toxinas, estabelecendo limites máximos de concentrações aceitáveis de $1,0 \mu \mathrm{g} / \mathrm{L}, 3,0 \mu \mathrm{g} / \mathrm{L}$ e 15,0 $\mu \mathrm{g} / \mathrm{L}$ para microcistinas, saxitoxina e cilindrospermopsina, respectivamente.

Diversos estudos recentes realizados no Brasil mostram a ocorrência de cianobactérias tóxicas por todo o país, em reservatórios de abastecimento público, lagos artificiais, lagoas salobras e rios (Azevedo et al., 1994; Costa \& Azevedo, 1994; Yunes et al., 1996). Nas represas Billings e Guarapiranga, no Estado de São Paulo, a 
presença de cianobactérias tóxicas tem sido detectada principalmente pelo grupo de monitoramento da CETESB e vários gêneros já foram isolados destes reservatórios (Lagos et al., 1999; Sant'Anna e Azevedo, 2000; Souza et al., 1998).

\subsection{Métodos para detecção de cianobactérias e suas toxinas em águas}

Para atendimento ao padrão de potabilidade da água para consumo humano a Portaria 1469 de 29/12/2000 do Ministério da Saúde (Brasil, 2000) exige apenas a análise das microcistinas, por serem as mais comumente encontradas e apresentarem alternativas metodológicas mais simplificadas, com o VMP (valor máximo permitido) de $1,0 \mu \mathrm{g} / \mathrm{L}$.

De acordo com essa mesma Portaria, o monitoramento de cianobactérias na água do manancial, no ponto de captação, deve obedecer uma freqüência mensal, quando o número de cianobactérias não exceder 10.000 células $/ \mathrm{mL}$ (ou $1 \mathrm{~mm}^{3} / \mathrm{L}$ de biovolume), e semanal, quando exceder este valor. Também é vedado o uso de algicidas para o controle do crescimento de cianobactérias ou qualquer intervenção no manancial que provoque a lise das células destes microrganismos, quando a densidade das cianobactérias exceder 20.000 células/ $\mathrm{mL}$ (ou $2 \mathrm{~mm}^{3} / \mathrm{L}$ de biovolume), sob pena de comprometimento da avaliação de riscos à saúde associados às cianotoxinas.

Normalmente, os levantamentos sobre ocorrência de florações de cianobactérias

em reservatórios de água são realizados através de técnicas convencionais de observação em microscópio ótico das amostras coletadas e/ou isolamento e cultivo destes microrganismos (Bouvy et al., 1999, 2000; Branco \& Senna, 1994; Domingos et al., 1999; Lagos et al., 1999; Sant'Anna \& Azevedo, 2000; Souza et al., 1998). Entretanto, a identificação de espécies através da análise morfológica não indica adequadamente o potencial para produção de toxinas desses organismos. Linhagens de uma mesma espécie podem ser morfologicamente idênticas, mas apresentarem diferenças quanto à toxicidade. Assim, a espécie Microcystis aeruginosa possui linhagens tóxica e não tóxica (Meissner et al., 1996).

A detecção de cianobactérias a partir do isolamento e cultivo destes microrganismos é útil para espécies de crescimento rápido e com meio seletivo bem definido. Sabe-se, porém, que populações de Microcystis aeruginosa são encontradas 
na natureza segundo características específicas quanto à forma e o tamanho de suas colônias (Reynolds et al., 1980; Sant'Anna \& Azevedo, 2000). Entretanto, após longo período de cultivo em laboratório muitas perdem as características específicas de suas colônias. Dessa forma, Komárek \& Anagnostidis (1989) relatam que os aspectos de mais de $50 \%$ das linhagens existentes nas coleções de culturas de cianobactérias não correspondem às características do táxon nas quais elas foram incluídas. Além disso, existem cianobactérias, assim como muitas bactérias de um modo geral, que são resistentes aos métodos de cultivo existentes atualmente (Pace, 1997). Para bactéria de um modo geral, é sabido que menos de $1 \%$ dos organismos existentes nos ambientes naturais são capazes de crescer em meio de cultura, ou seja, 99\% ainda permanecem desconhecidos (Amann et al., 1995).

Para avaliar a toxicidade das cianobactérias presentes nas florações, os métodos usados atualmente compreendem os bioensaios e/ou ensaios fisico-químicos, sendo os primeiros utilizados para aferir os efeitos das toxinas nos ecossistemas e os últimos para quantificá-las. Em bioensaios, utilizam-se como organismos teste mamíferos (camundongos), invertebrados (Daphnias, Artemia) ou bactérias (Fischer \& Dietrich, 2000; Harada et al., 1999; Pierce \& Kirkpatrick, 2001). Em alguns casos, tem-se também aplicado ensaios de citotoxicidade, ensaios enzimáticos e ainda ensaios com anticorpos (Ann \& Carmichael, 1994; Harada et al., 1999).

0 primeiro teste para detectar microcistinas onde não utilizou-se animais foi documentado por Carmichael \& Bent (1981). Esses autores desenvolveram um sistema de detecção baseado em hemaglutinação, onde as células de cianobactérias foram lavadas em solução salina e misturadas com células vermelhas de camundongos, de ratos ou humanas. Somente as estirpes que produziam toxinas, confirmadas pelo teste de $\mathrm{DL}_{50}$ em camundongos, aglutinaram as células vermelhas. Esse método foi usado para detectar toxinas em amostras ambientais e culturas de laboratório.

Um outro método baseado na inibição da atividade de fosfatases de proteínas dos tipos 1 e 2A foi descrito por Ash et al (1995). Apesar de demonstrar inibição das enzimas pela toxina purificada, a aplicação para amostras ambientais, contendo grande volume de água, não foi discutida. 
Kos et al (1995) apresentaram um teste biológico utilizando a inibição do crescimento de sementes de Sinapis alba L. após germinação. Boa correlação entre a quantidade da toxina microcistina usada e inibição de crescimento foi relatada. Os autores concluíram que esse teste é uma alternativa para detecção de toxinas em amostras ambientais, sem a necessidade de se utilizarem animais.

Os testes com maior aceitação têm sido, sem dúvida, àqueles que usam anticorpos como Radio Imuno Ensaio (RIA) ou ELISA (Enzyme Linked Immuno Sorbent Assay). O grupo de Chu et al (1989) documentou a produção e caracterização de anticorpos contra microcistina-LR, concluindo que estes anticorpos tinham atividade cruzada contra várias formas de microcistinas, porém com afinidade variável. Um estudo mais detalhado, realizado por Saito et al (1994), comparou anticorpos monoclonais produzidos contra microcistina-LR quanto à habilidade de reagir com outras variantes da toxina. Utilizando ELISA, observaram que os anticorpos monoclonais reagiram com microcistina-RR, 3,7-didesmetilmicrocistina, 7desmetilmicrocistina e também com algumas substâncias presentes no extrato de células não-tóxicas. Os autores concluíram que esses anticorpos reconheceram epitopos comuns para todos os peptídeos cíclicos e não só especificamente moléculas tóxicas. Desde 1989 vários grupos têm utilizado ELISA para detectar microcistina em amostras ambientais (Chu et al., 1990; McDermott et al., 1995; Ueno et al., 1996) visando chamar a atenção para a magnitude do problema envolvendo a presença de microcistinas em águas de abastecimento e a ameaça à saúde pública.

Em muitas ocasiões, após a detecção das toxinas das cianobactérias, é necessário proceder a sua identificação e quantificação recorrendo-se aos ensaios físico-químicos (Dickman \& Han, 1995; Yacobi et al., 1996). Um método bastante utilizado é o HPLC, técnica dispendiosa e lenta, mas imprescindível para a correta quantificação das toxinas presentes numa amostra.

Uma alternativa para os métodos tradicionais de isolamento e cultivo de cianobactérias, seguidos de bioensaios e/ou ensaios físico-químicos visando a identificação e detecção de suas toxinas, são as técnicas moleculares. Essas técnicas têm oferecido uma abordagem inovadora, sensível e específica com potencial de aplicação em ambientes naturais. Também podem propiciar o acesso a um maior 
número de microrganismos presentes em amostras ambientais (Rosado et al., 1997), inclusive àqueles não cultiváveis (Macnaughton et al., 1999).

Um importante avanço na área de ecologia microbiana foi o uso da seqüência do gene que codifica para o rRNA 16S, uma "impressão digital" molecular que pode ser utilizada para identificar microrganismos em ambientes naturais, permitindo 0 desenvolvimento de técnicas independentes do cultivo para a análise da diversidade da comunidade (Amann et al., 1995). Utilizando oligonucleotídeos iniciadores específicos para a região conservada do rRNA 16S é possível, através de PCR, gerar produtos com tamanho de fragmentos semelhantes, mas com características de C $+\mathrm{G}$ diferentes. A variabilidade da seqüência pode ser analisada através de eletroforese em gel de poliacrilamida com gradiente desnaturante (DGGE) (Cury, 2002; Muyzer et al., 1993; Teske et al., 1996). A DGGE utiliza géis de poliacrilamida contendo um gradiente linear de desnaturantes (uréia e formamida). Moléculas de DNA com tamanhos semelhantes, mas com seqüências diferentes de nucleotídeos, apresentam comportamento eletroforético diferente quando expostas ao gradiente de agentes desnaturantes. A seqüência de nucleotídeos (conteúdo de $\mathrm{G}+\mathrm{C}$ ) de um fragmento de DNA definirá a posição no gradiente em que o DNA de fita dupla irá se desnaturar. Desde que moléculas de DNA com seqüências diferentes apresentam taxas de migração diferentes em géis desnaturantes, essa técnica é uma ferramenta bastante útil para a realização de estudos ecológicos com microrganismos (Rosembaum \& Riesner, 1987).

A amplificação de regiões hipervariadas do rRNA 16S por PCR, e posterior análise por meio de DGGE, tem permitido a determinação da estrutura das comunidades microbianas em diferentes condições ambientais (Heuer \& Smalla, 1997), incluindo comunidades aquáticas (MacGregor, 1999). Nübel et al (1997) desenvolveram um conjunto de oligonucleotídeos iniciadores do gene de rRNA 16S específico para 0 grupo de cianobactérias, os quais podem ser usados na combinação das técnicas PCR e DGGE em estudos de biodiversidade de cianobactérias no hábitat natural. Vários outros estudos posteriores foram realizados usando esse conjunto de iniciadores (Garcia-Pichel et al., 2001; López-Cortés et al., 2001; Nübel et al., 1999). Essa metodologia permitiu detectar cianobactérias presentes em diferentes ecossistemas inclusive ambientes extremos, tais como hipersalinos, desérticos, águas termais. 
Outra abordagem molecular para estudar comunidades bacterianas em ambientes naturais é a construção de mini-bibliotecas de seqüências gênicas, com subseqüente clonagem e sequenciamento (Kelly \& Chistoserdov, 2001; Rappé et al., 2000; Suzuki et al., 2001). Embora essa abordagem seja mais trabalhosa ela elimina determinados problemas existentes na técnica de DGGE, tais como tamanho do fragmento das seqüências e ajuste do gradiente desnaturante.

A detecção de algumas cianobactérias toxigênicas por meio de métodos moleculares somente foi possível recentemente, após a identificação e sequenciamento dos genes envolvidos na biossíntese das toxinas (Christiansen et al., 2003; Schembri et al., 2001; Tillet et al., 2000; Wilson et al., 2000). Assim, oligonucleotídeos iniciadores têm sido desenhados tendo como alvo seqüências específicas desses genes, permitindo a amplificação por PCR e conseqüentemente a detecção das cianobactérias que os possuem. Dessa forma, num futuro próximo, métodos rápidos de dignóstico (resultado em horas) e específicos (sem falso positivos) para a detecção de cianobactérias tóxicas deverão estar disponíveis, tendo como base seqüências específicas de genes de toxinas. Tillett et al. (2001) foram os pioneiros a utilizar a seqüência de DNA que codifica para o domínio único de $\mathrm{N}$-metiltransferase (NMT) presente no gene da enzima multifuncional sintetase de peptídeo, mcyA, para desenhar oligonucleotídeos iniciadores que possibilitassem a identificação de Microcystis toxigênicas. Até o momento, os poucos trabalhos publicados (Baker et al., 2001, 2002; Bittencourt-Oliveira, 2003; Kurmayer et al., 2002, 2003; Neilan et al., 1999; Tillett et al., 2001) sobre PCR específico para detecção de toxinas de cianobactérias, mostram que nas espécies onde os genes envolvidos na biossíntese destas são detectados, eles também estão sendo expressos nas células.

Recentemente, Fergusson \& Saint (2003) desenvolveram um método de PCR multiplex para identificar simultaneamente a cianobactéria Cylindrospermopsis raciborskii e a toxina cilindrospermopsina produzida por este gênero. Eles utilizaram um conjunto de iniciadores de PCR desenhados para amplificar o gene rpoC1 (RNA polimerase dependente de DNA) de C. raciborskii (Wilson et al., 2000) e outro conjunto de iniciadores que amplificam fragmentos dos genes ps e pks, os quais estão envolvidos com a produção da toxina cilindrospermopsina (Schembri, et al., 2001). Um 
dos iniciadores de pks necessitou de alteração para produzir amplicons de menor tamanho na PCR, facilitando a identificação dos múltiplos produtos através de eletroforese em gel. Em amostras onde nenhum produto de PCR para $C$. raciborskiiespecífico nem os determinantes pks ou ps foram amplificados, a amplificação do ICF (fragmento interno de controle) mostrou que as amostras eram verdadeiramente negativas, não havendo inibição da reação de PCR por componentes presentes nas mesmas.

Essas técnicas moleculares, uma vez bem estabelecidas para organismos isolados, poderão proporcionar base suficiente para aplicação em amostras ambientais, o que poderá propiciar uma melhor e mais rápida detecção de comunidades aquáticas produtoras de toxinas em ambientes naturais. O rápido diagnóstico da ocorrência natural de certos grupos de cianobactérias tóxicas em águas é importante para a classificação biológica da qualidade destas águas, podendo estes microrganismos também funcionar como bioindicadores de poluição.

Algumas seqüências de genes são atualmente mais utilizadas para identificar cianobactérias e suas toxinas e uma descrição mais detalhada delas é dada abaixo.

\subsubsection{Subunidade 16S do RNA ribossômico (rRNA 16S)}

Os genes rrs, rrl e rrf codificam para os RNAs ribossomais 16S, 235 e $5 \mathrm{~S}$ respectivamente (Figura $1 \mathrm{~A}$ ). Os RNAs ribossômicos (rRNA) são componentes essenciais dos ribossomos envolvidos na tradução do RNA mensageiro (mRNA) para a síntese de proteínas. Os genes que os codificam, distribuídos universalmente, apresentam um grau de conservação elevado e podem acumular variabilidades em maior ou menor grau em diferentes regiões da molécula (Lane et al., 1985). Essa é uma das grandes vantagens de informações de seqüências de rRNA, pois uma vez obtidas, elas podem ser depositadas em banco de dados especializados (RDP, GenBanK, EMBL), ficando disponíveis para estudos posteriores.

Seqüências do gene de rRNA 16S são independentes de cultivo ou condições de crescimento. Além da alta conservação entre as espécies, a sua larga utilização é atribuída à grande quantidade de rRNA na maioria das células, à aparente ausência de 


\section{A.}

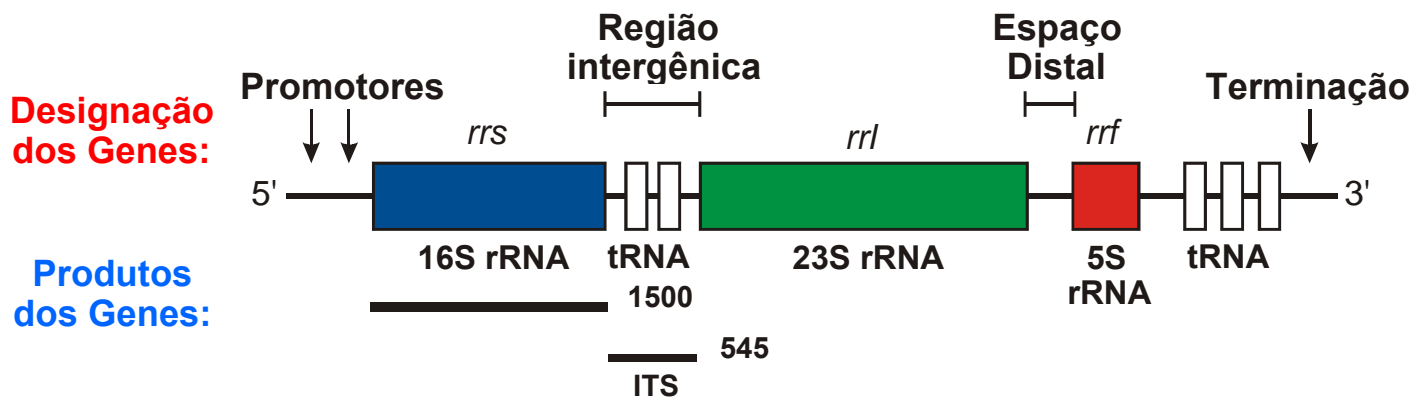

B.

Designação dos Genes:

Região Intergênica

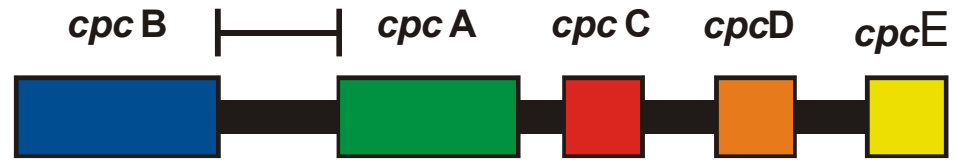

$94 \mathrm{pb}$

C. $685 \mathrm{pb}$

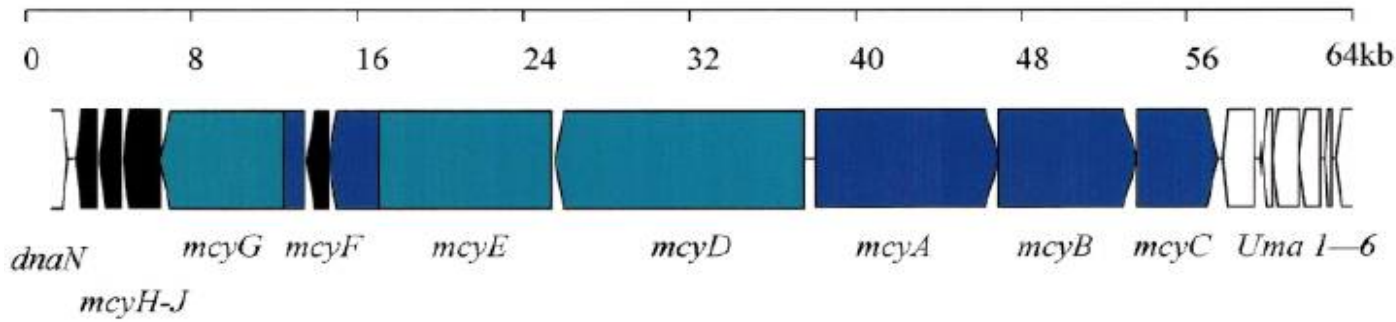

Figura 1 - A. Organização do operon do rRNA ribossômico; B. Operon da ficocianina; C. Operon da microcistina. 
transferência genética lateral e a um tamanho satisfatório (cerca de 1500 nucleotídeos), permitindo inferências filogenéticas (Amann \& Ludwig, 2000).

Com a automação das técnicas de sequenciamento de ácidos nucléicos, a utilização de seqüências de rRNA 16S teve grande impacto como marcador molecular, resultando em grande número de seqüências de rRNAs microbianos disponíveis em bases de dados. Essas podem ser usadas para a construção de árvores filogenéticas, mostrando as relações entre os organismos estudados, além de permitir a análise de seqüências que evoluem em diferentes níveis (Woese, 1987). O alinhamento das seqüências de grupos de interesse pode fornecer ainda informações sobre regiões da molécula adequadas ao desenho de oligonucleotídeos específicos para os diferentes grupos, podendo abranger níveis taxonômicos. Grande variedade de sondas ribossômicas específicas para gêneros, espécies ou linhagens tem sido desenvolvida para estudos de ecologia microbiana (Rosado et al., 1996; Woese, 1987).

Os estudos de rRNA 16S de cianobactérias foram iniciados em 1975 e confirmaram a estrutura bacteriana destes organismos (Bonen \& Doolittle, 1975; Woese et al., 1975). Vários outros estudos têm sido publicados desde então (Bonen \& Doolittle, 1976, 1978; Bonen et al., 1979; Giovannoni et al., 1988; Neilan et al., 1994, 1997; Nelissen et al., 1992, 1995a, 1995b, 1996; Palinska et al., 1996; Turner, 1997; Weller et al., 1991; Wilmotte et al., 1992, 1993, 1994) e uma revisão sobre este assunto pode ser encontrada em Wilmotte (1994).

\subsubsection{Região do espaço intergênico da ficocianina (PC-IGS)}

Outros genes, tais como rpoC1 e PC-IGS, também têm sido utilizados para análises filogenéticas de cianobactérias e avaliação da estrutura de comunidades (Bergsland \& Haselkorn, 1991; Neilan et al., 1995; Palenik, 1992). São usados como alternativas em relação ao rRNA 16S, o qual em alguns casos apresenta variações insuficientes em suas seqüências para separar espécies próximas relacionadas. Entretanto, os dados de seqüências disponíveis para esses genes ainda são limitados, quando comparados aos de seqüências de rRNA 16S depositadas em bancos de dados.

O aparato fotossintético das cianobactérias possui Chl a, ficobiliproteínas e vários carotenóides como pigmentos da antena coletora de luz (Stanier \& Cohen-Bazire, 
1977). O principal pigmento da antena coletora de luz são as ficobiliproteínas que são organizadas em uma estrutura chamada ficobilissomas, as quais, por sua vez, são compostas de ficoeritrina (um pigmento vermelho que está ausente em algumas cianobactérias), ficocianina (PC - um pigmento azul), aloficocianina e aloficocianina B (Stanier \& Cohen-Bazire, 1977). Dentro do domínio Bacteria, os genes de PC são encontrados em ambientes de água doce exclusivamente em cianobactérias (Bryant, 1982; Ernest, 1991; Glazer, 1989). Alguns outros organismos, tais como algas vermelhas (rodófita) e criptófita também possuem esses genes de PC (Apt et al., 1995). 0 operon PC (Figura $1 B$ ) possui uma região de espaço intergênico ( $\mathrm{PCl}-\mathrm{GS}$ ) entre os dois genes, $c p c B$ e $c p c A$, que é relativamente grande, se comparada com outras existentes nos genes do pigmento fotossintético de cianobactérias. Essa região apresenta variações suficientes na seqüência permitindo a identificação de diferentes linhagens de cianobactérias (Bolch et al., 1996; Neilan et al., 1995). Todas essas características do PC-IGS propiciam uma maneira rápida e direta para a identificação de cianobactérias.

\subsubsection{Domínio $\mathbf{N}$-metiltransferase do gene mcyA}

As microcistinas são pequenos peptídeos contendo aminoácidos incomuns, sintetizados sem a participação direta do ribossomo, através de uma série de reações catalizadas por enzimas multifuncionais chamadas de sintetase de peptídeos (PS) e sintase de policetônicos (PKS) (Arment \& Carmichael, 1995; Dittmann et al., 1997).

Caracterizadas como hepatotoxinas, as microcistinas têm sido as mais estudadas por causarem problemas no mundo todo. Elas são produzidas por cianobactérias dos gêneros Microcystis, Oscillatoria, Anabaena, Nostoc (Carmichael, 1992) e Planktothrix (Hisbergues et al., 2003). Até o momento, 60 variantes de microcistinas foram caracterizadas, podendo-se diferenciá-las quanto à toxicidade (Sivonen \& Jones, 1999). Estudos referentes aos mecanismos de ação dessas hepatotoxinas têm demonstrado que várias microcistinas são potentes inibidores de proteínas fosfatases tipo 1 e 2A de células eucariontes (Honkanen et al., 1990).

Recentemente, os genes envolvidos na biossíntese da microcistina-LR da cianobactéria Microcystis aeruginosa PCC7806 foram isolados e seqüenciados (Tillet et 
al. 2000). Alguns desses genes têm sido utilizados para uma rápida e sensível detecção de cianobactérias tóxicas e não tóxicas (Bittencourt-Oliveira, 2003; Vaitomaa et al., 2003; Tillett et al., 2001).

0 agrupamento dos genes que participam da biossíntese da microcistina, denominado mcy, contém $55 \mathrm{~kb}$ de DNA codificando dez (10) ORFS (quadro aberto de leitura), mcyA-mcy (Tillett et al., 2000) (Figura 1C). Essas ORFs são flanqueadas em ambos os lados por genes que não estão envolvidos na biossíntese da toxina (dna $\mathrm{N} \mathrm{e}$ uma 1-6), e que apresentam alta similaridade com os genes localizados no cromossomo de Synechocystis sp. PCC6803. Esse fato sugere fortemente que o agrupamento mcy está localizado no cromossomo e não no plasmídeo como previamente proposto (Bolch et al., 1997). Dois operons transcritos em direções opostas também foram constatados: mcyD-J (operon maior) e mcyA-C (operon menor). A região $m c y D$-J (operon maior) contém sete (7) ORFs, todas transcritas em direção oposta ao operon menor, que contém três (3) ORFs. Tillett et al. (2001) desenharam um conjunto de iniciadores de PCR que amplificam a seqüência de DNA que codifica para o domínio único de $\mathrm{N}$ metiltransferase (NMT) do gene mcyA, que permitem a identificação de Microcystis toxigênicas. Utilizando esse domínio, Baker et al. (2002) estudaram a determinação direta de cianobactérias potencialmente tóxicas na represa de Malpas, na região de Nova Inglaterra, Austrália. Esses autores, além de detectar linhagens tóxicas de Anabaena e Microcystis sp. presentes no local, mostraram também que ao longo do curso de suas florações, estes organismos apresentavam mudanças nos tipos de célula e toxicidade.

Recentemente, Vaitomaa et al (2003) utilizaram a técnica de PCR em tempo real para a determinação do número de cópias de uma seqüência do gene mcyE em dois dos principais gêneros de cianobactérias produtores de microcistinas, Microcystis e Anabaena, os quais estavam presentes nos lagos Tuusulanjärvi e Hiidenvesi, na Finlândia. 


\subsection{Os resenvatórios Billings e Guarapiranga}

\subsubsection{Reservatório Billings}

O reservatório Billings localiza-se a oeste de São Paulo, nas coordenadas $23^{\circ} 47^{\prime} \mathrm{S}$ e $46^{\circ}$ e $40^{\prime} \mathrm{W}$, a uma altitude de $746 \mathrm{~m}$. Sua área é de $120 \mathrm{~km}^{2}$ e seu volume de $1,20 \times 109 \mathrm{~m}^{3}$ (Souza et al., 1998). Esse reservatório, morfologicamente, constitui-se num corpo central alongado e estreito, ligado a diversos braços, alguns de grande volume. Em função dessa conformação, o afluxo de água dá-se preferencialmente ao longo do seu canal central. Isso faz com que a maior parte do volume de água presente nos braços fique de certa forma isolado do corpo central na maior parte do tempo (CETESB, 2003).

O reservatório Billings foi idealizado pelo engenheiro americano Asa Billings, em 1927, com a finalidade de aproveitar as águas do Alto Tietê para geração de energia elétrica nas usinas de Cubatão. Para que isso fosse possível, foi necessária a construção de um sistema de obras hidráulicas de maneira a permitir que as águas do Alto Tietê atingissem o reservatório. Desse modo, ele pode receber as águas da bacia do rio Tietê através da estação de recalque de Pedreira, situada junto à barragem de mesmo nome do rio Pinheiros, de onde suas águas são conduzidas para as usinas de Cubatão através da barragem reguladora do canal das Pedras (Summit Control). Através do "Summit Control" as águas passam para o reservatório do rio das Pedras de onde são aduzidas diretamente para as usinas de Cubatão (CETESB, 2003).

0 reservatório atua como elemento regularizador das descargas de sua bacia contribuinte e das descargas do rio Tietê, que recebe através do rio Pinheiros. A partir de 1992 passou a ocorrer um menor aporte das águas poluídas provenientes dos rios Pinheiros e Tietê para o compartimento Pedreira do reservatório Billings. Isso ocorreu em razão do menor volume de água bombeado na Usina Elevatória de Pedreira, em atendimento à Resolução Conjunta SMNSES $n^{\circ}$ 3, de 04109/92, que autoriza 0 bombeamento das águas do Canal do Pinheiros em condições específicas, principalmente riscos de enchentes na Região Metropolitana de São Paulo (RMSP). Esse fato propiciou nos anos seguintes uma melhoria na qualidade das águas desse compartimento. 
A partir de agosto de 2000, a SABESP iniciou a operação do sistema de adução de água bruta do braço do Taquacetuba para o reservatório Guarapiranga, com uma Licença de Operação para $2,0 \mathrm{~m}^{3} / \mathrm{s}$.

Embora idealizado para a geração de energia elétrica, o reservatório tem sido utilizado para diversas atividades de lazer como esportes náuticos, natação e pesca. Em função das cianobactérias potencialmente tóxicas existentes na Billings, o reservatório está sendo monitorado numa freqüência mais intensa (CETESB, 2003). A SABESP também implantou um monitoramento da qualidade da água em tempo real por um sistema de bóia com transmissão dos dados por satélite.

As espécies de cianobactérias Aphanocapsa incerta, Microcystis aeruginosa, Anabaena planctonica, A. solitaria, A. spiroides, Cylindrospermopsis raciborskii, Raphidiopsis mediterranea, Oscillatoria agardhii, O. quadripunctulata, O. amphibia, Lyngbya limnetica e Pseudoanabaena catenata já foram isoladas da Billings (Lagos et al., 1999; Sant'Anna e Azevedo, 2000; Souza et al., 1998). Em 1996, isolou-se pela primeira vez uma espécie de cianobactéria freqüentemente observada na represa Billings e produtora de uma potente toxina, a Cylindrospermopsis raciborskii (Lagos et al., 1999). Foi também o primeiro relato da ocorrência de neurotoxinas do tipo PSP (Paralytic Shellfish Poisons) produzida por uma cianobactéria na América do Sul.

Além disso, no compartimento Rio Grande isolado do sistema Billings, desde 1982, ocorre a captação de água para o abastecimento público da região do ABC.

Segundo o Sindicato dos Pescadores Artesanais existem cerca de 2000 pescadores atuando no reservatório, gerando renda para aproximadamente 480 famílias. A pesca profissional retira diariamente de 10 a 12 toneladas de pescado. As duas aldeias indígenas próximas à represa Billings, ambas com 110 famílias guarani, totalizam aproximadamente 700 pessoas que também praticam a pesca para obter parte do alimento para sua subsistência (CETESB, 2003). Entretanto, a ocupação desordenada pelo homem ao redor dos reservatórios tem como conseqüência 0 aumento da eutrofização destes corpos d'água, favorecendo a proliferação de cianobactérias, dentre elas as produtoras de toxinas. 


\subsubsection{Reservatório Guarapiranga}

O reservatório do Guarapiranga situa-se na bacia do Alto Tietê, na Região Metropolitana de São Paulo (RMSP) e foi construído entre 1906 e 1908, destinado à regularização da vazão do rio Tietê e à geração de energia elétrica. Ele é formado pelo represamento do rio Guarapiranga e dos afluentes Laura, Santa Rita, Embu-Guaçu, Embu-Mirim, Ribeirão Mirim e outros 17 córregos de menor extensão. Possui um perímetro de $85 \mathrm{~km}$, uma área de $33,91 \mathrm{~km}^{2}$ e um volume de $194 \times 106 \mathrm{~m}^{3}$. Suas profundidades média e máxima são, respectivamente, de 5,7 $\mathrm{m}$ e 13,0 m. Esse reservatório localiza-se nas coordenadas $23^{\circ} 43^{\prime}$ latitude Sul e $46^{\circ} 32^{\prime}$ longitude Oeste de Greenwich, a uma altitude de 740m. A partir de 1927, passou a ser utilizado como manancial para abastecimento público da cidade de São Paulo. Atualmente, contribui com cerca de $20 \%$ da água de abastecimento da RMSP (CETESB, 2003).

A bacia hidrográfica do Guarapiranga insere-se na porção sudoeste da RMSP, abrangendo parcelas territoriais dos municípios de São Paulo, Taboão da Serra, Embu, Itapecirica da Serra, Embu-Guaçu (este integralmente), Cotia, São Lourenço da Serra e Juquitiba. Com cerca de $640 \mathrm{Km}^{2}$, a bacia corresponde a aproximadamente $8 \%$ da RMSP e 15\% da área coberta pela Legislação de Proteção de Mananciais - LPM ( Lei n.o 9866/97).

O censo de 1991 registrou uma população de 548.000 habitantes para 0 território, atualmente estimam-se cerca de 622 mil habitantes concentrados nas áreas mais próximas ao reservatório. A ocupação dessa região deu-se, principalmente, por população de baixa renda, em favelas e loteamentos clandestinos.

Apesar de abrigar um dos mais importantes mananciais de abastecimento da RMSP, a bacia do Guarapiranga vem sofrendo um contínuo e crescente processo de degradação ambiental, observado desde o final da década de 60, fruto da urbanização intensificada da metrópole paulista. Dessa época, datam diversos estudos técnicos que já indicavam os riscos de crescente perda da qualidade das águas do reservatório. Em função disso, durante a década de 70, o Estado passou a definir uma política pública de proteção dos mananciais. Em 1974, já se verificava uma ocupação significativa ao longo dos braços da represa Guarapiranga, em especial na margem esquerda, onde se situa a Capela do Socorro. 
Com a ocupação crescente na bacia, houve um acréscimo significativo da carga orgânica para o reservatório, causando um processo de eutrofização, que vem se acentuando nos últimos anos. Em 1982 os fenômenos de floração de cianobactérias começaram a ser recorrentes, acarretando graves conseqüências para o abastecimento, já que comprometem a qualidade da água, tanto pelo entupimento dos filtros das estações de tratamento, quanto por conferir gosto e odor à água. A ocorrência de episódios mais críticos de florações de cianobactérias no reservatório Guarapiranga tem sido registrada pela SABESP, tanto na estiagem (inverno) como no verão (CETESB, 2003).

Além de fornecer água para abastecimento, o reservatório Guarapiranga é utilizado pela população também como área de lazer para fins recreacionais tais como a pesca, banho e esportes náuticos. A freqüência de banhistas e dos praticantes de esportes náuticos é muito acentuada nos fins de semana, principalmente no verão. Por esse motivo, a CETESB vem monitorando a qualidade da água para fins recreativos do reservatório do Guarapiranga desde 1992. 


\section{MATERI AL E MÉTODOS}

\subsection{Coleta das amostras ambientais}

As amostras de água das represas Billings e Guarapiranga analisadas neste estudo foram fornecidas pelo grupo de monitoramento da CETESB (Companhia de Tecnologia de Saneamento Ambiental, São Paulo, SP), e coletadas nos diversos pontos da área monitorada por esta Companhia (Tabela 1, Figura 2). As amostras foram coletadas numa profundidade de 0-20 cm, acondicionadas em frascos de $1 \mathrm{~L}$, transportadas para o laboratório e armazenadas a $4^{\circ} \mathrm{C}$.

Após a retirada de $1,0 \mathrm{~mL}$ de água do volume total amostrado de cada ponto para utilização no isolamento de cianobactérias, o volume restante foi filtrado em peneira de 300 mesh ( 325 mesh $\cong 45 \mu \mathrm{m}$ ). Em seguida, cada amostra foi concentrada através de centrifugação a $13000 \times \mathrm{g}$, durante $15 \mathrm{~min}$ a temperatura de $4^{\circ} \mathrm{C}$. O material concentrado de cada amostra (pélete com aproximadamente $4 \mathrm{~mm}$ ) foi lavado três vezes com água ultrapura (Milli-Q, Millipore, E.U.A.), autoclavada $\left(121^{\circ} \mathrm{C}, 20 \mathrm{~min}\right)$, e ressuspendido em $200 \mu \mathrm{L}$ desta mesma água. Esse volume foi divido em 2 partes iguais em microtubos de $1,5 \mathrm{~mL}$, os quais foram armazenados a temperatura de $-20^{\circ} \mathrm{C}$.

\subsection{I solamento e cultivo de cianobactérias}

O isolamento de cianobactérias das amostras de água coletadas nas represas Billings e Guarapiranga foi realizado utilizando-se a metodologia descrita por Whitton (1996), conforme a seguir. As alíquotas de $1 \mathrm{~mL}$ de água foram inoculadas, sob condições assépticas, em tubos de ensaio contendo $9 \mathrm{~mL}$ dos diferentes meios de cultura (Tabela 2 ), esterilizados em autoclave $\left(121^{\circ} \mathrm{C}\right.$, durante $\left.20 \mathrm{~min}\right)$. Foram feitas

diluições até $10^{-3}$. Os tubos foram colocados sob iluminação fluorescente constante de $30 \mu \mathrm{E} \cdot \mathrm{m}^{2} \mathrm{~s}^{-1}$ e temperatura controlada de $24 \pm 1^{\circ} \mathrm{C}$, onde permaneceram cerca de $20 \mathrm{a}$ 30 dias ou até o crescimento visivelmente constatado. 
Tabela 1. Identificação das amostras ambientais usadas neste estudo, épocas de amostragens e locais de coletas.

\begin{tabular}{ccccl}
\hline \multicolumn{2}{c}{ AMOSTRAS } & COLETA & DATA & \multicolumn{1}{c}{ LOCAL } \\
\hline \# CETESB & \# CENA & Colacão da SABESB (BITQ00100) \\
\hline 95714 & $1-2$ & 1 a coleta & $18 / 07 / 2001$ & Billings, Braço do Taquacetuba - captaça \\
95716 & $3-4$ & 1 a coleta & $18 / 07 / 2001$ & Billings, Braço do Taquacetuba - na linha de transmissão (BITQ00900) \\
97263 & $5-6$ & 2 a coleta & $15 / 08 / 2001$ & Billings, Braço do Taquacetuba - na linha de transmissão (BITQ00900) \\
98481 & $7-8$ & 2 a coleta & $29 / 08 / 2001$ & Billings, Braço do Taquacetuba - na linha de transmissão (BITQ00900) \\
98479 & $9-10$ & 2 a coleta & $29 / 08 / 2001$ & Billings - no meio do Corpo Central, na direção do Braço do Bororé (BILL02100) \\
23765 & $11-12$ & 3 a coleta & $19 / 06 / 2002$ & Billings, Braço do Taquacetuba - captação da SABESB (BITQ00100) \\
26874 & $13-14$ & 3 a coleta & $03 / 07 / 2002$ & Billings - no meio do Corpo Central, na direção do Braço do Bororé (BILL02100) \\
29160 & $15-16$ & 4 a coleta & $14 / 08 / 2002$ & Billings, Braço do Taquacetuba - captação da SABESB (BITQ00100) \\
29165 & $17-18$ & 4 a coleta & $14 / 08 / 2002$ & Guarapiranga - captação da SABESP, junto à casa de bombas (GUAR00900) \\
29162 & $19-20$ & 4 a coleta & $14 / 08 / 2002$ & Billings - no meio do Corpo Central, na direção do Braço do Bororé (BILL02100) \\
29167 & $21-22$ & 4 a coleta & $14 / 08 / 2002$ & Guarapiranga - próximo à foz do rio Parelheiros, no bairro de São José (GUAR00900) \\
\hline
\end{tabular}


A.

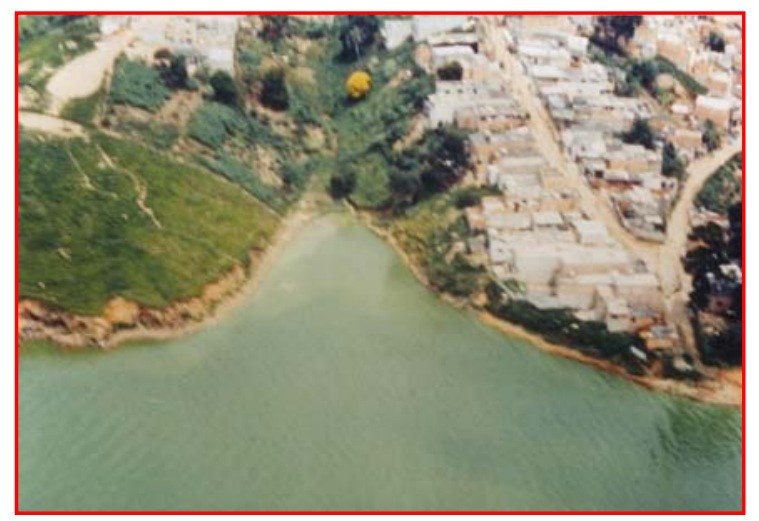

Fonte: CETESB, 2001

B.

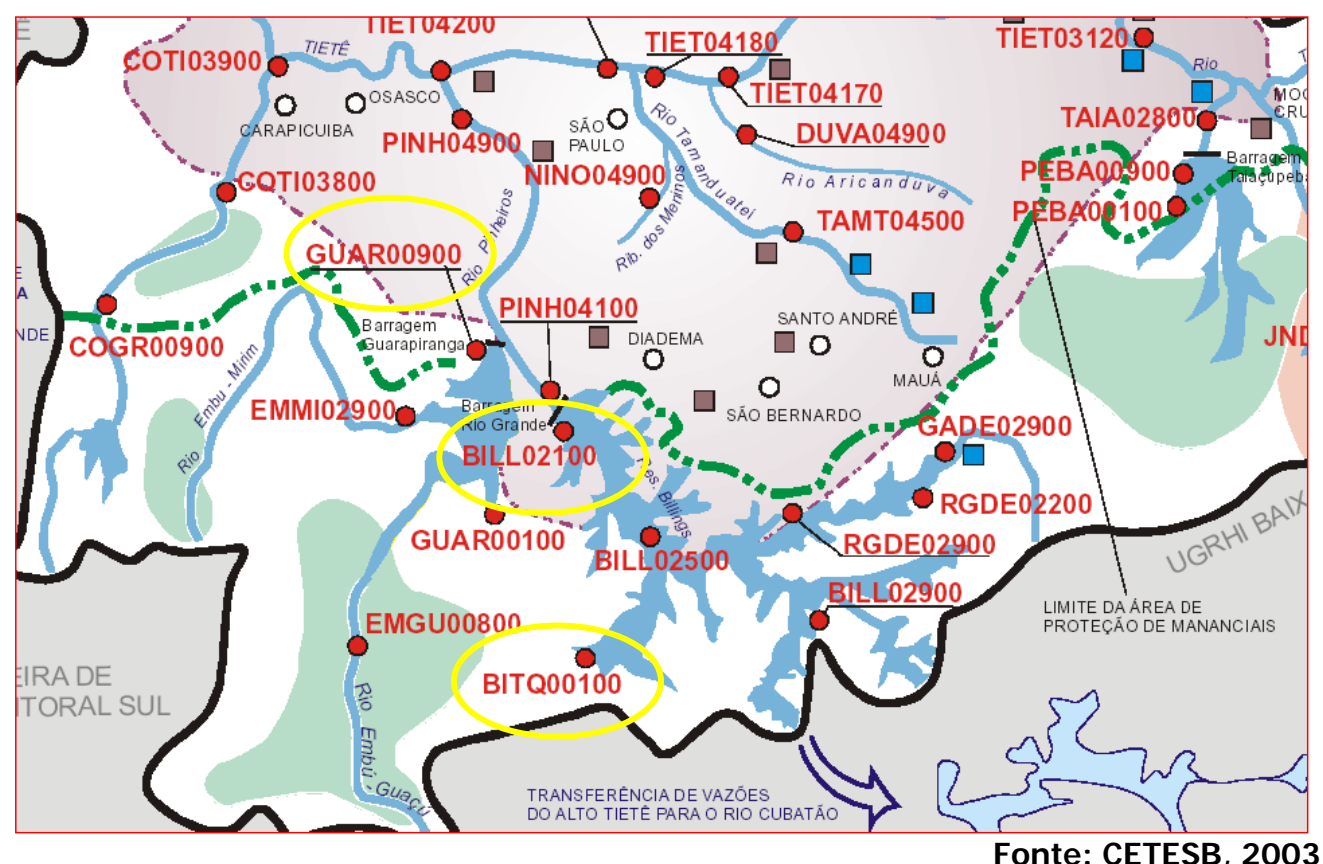

Figura 2 - A. Vista aérea de um local do braço Taquacetuba, represa Billings-SP; B. BILL02100, BITQ00100 e GUAR00900 são alguns dos pontos de monitoramento da CETESB analisados neste estudo. 
Tabela 2. Meios de culturas usados no isolamento das cianobactérias (Whitton, 1996).

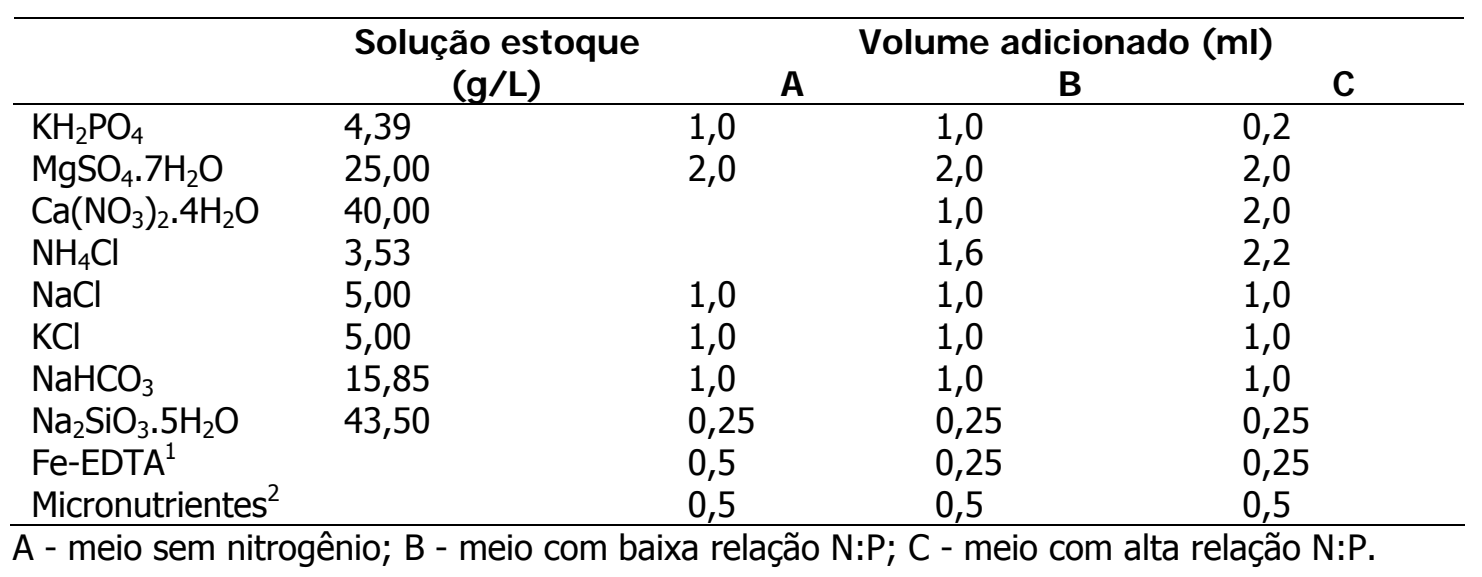

${ }^{1}$ Fe-EDTA - Preparar $100 \mathrm{~mL}$ de solução estoque contendo: $0,97 \mathrm{~g} \mathrm{FeCl}_{3} \cdot 6 \mathrm{H}_{2} \mathrm{O}+$ $1,335 \mathrm{~g} \mathrm{Na}_{2}$ EDTA

${ }^{2}$ Micronutrientes - Preparar $100 \mathrm{~mL}$ de solução estoque contendo:

\begin{tabular}{|c|c|}
\hline $\mathrm{H}_{3} \mathrm{BO}_{3}$ & $0,286 \mathrm{~g}$ \\
\hline $\mathrm{Na}_{2} \mathrm{MoO}_{4} \cdot 2 \mathrm{H}_{2} \mathrm{O}$ & $0,039 \mathrm{~g}$ \\
\hline $\mathrm{NiSO}_{4} \cdot 7 \mathrm{H}_{2} \mathrm{O}$ & $0,0048 \mathrm{~g}$ \\
\hline $\mathrm{MnCl}_{2} \cdot 4 \mathrm{H}_{2} \mathrm{O}$ & $0,181 \mathrm{~g}$ \\
\hline $\mathrm{CuSO}_{4} .5 \mathrm{H}_{2} \mathrm{O}$ & $0,0079 \mathrm{~g}$ \\
\hline $\mathrm{ZnSO}_{4} \cdot 7 \mathrm{H}_{2} \mathrm{O}$ & $0,022 \mathrm{~g}$ \\
\hline $\mathrm{Co}\left(\mathrm{NO}_{3}\right)_{2} \cdot 6 \mathrm{H}_{2} \mathrm{O}$ & $0,0049 \mathrm{~g}$ \\
\hline
\end{tabular}

Nota: Para cada $1 \mathrm{~L}$ de meio, adicionar $0,6 \mathrm{~g}$ de HEPES em $500 \mathrm{~mL}$ de água destilada (concentração final 2,5 mM HEPES); adicionar as outras soluções; ajustar o pH para 7,0 com NaOH 0,1 M e completar o volume para $1 \mathrm{~L}$. 
Passado esse período, as amostras foram inoculadas em placa de Petri contendo o mesmo meio, mas solidificado com $0,8 \%$ de agar Noble (Difco, Detroit, Michigan, E.U.A.). As placas foram vedadas e incubadas nas condições descritas acima. Repicagens sucessivas foram feitas, separando-se as colônias com crescimento diferenciado através de alça de platina esterilizada para novas placas, visando-se a obtenção de culturas puras.

Adicionalmente, algumas das linhagens de cianobactérias utilizadas neste estudo foram cedidas gentilmente pela Dra. M.T.P. Azevedo e Dra. C.L. Sant'Anna (Instituto de Botânica, Secretaria do Meio Ambiente, São Paulo-SP), e pela Dra. S.M.F.O. Azevedo (Universidade Federal do Rio de Janeiro, Rio de Janeiro-RJ). Dessas linhagens fornecidas, onze foram isoladas da represa Billings (Microcystis novacekii SPC503; Microcystis aeruginosa SPC777; Microcystis sp. SPC822; Sphaerocavum brasiliense SPC484; Pseudanabaena galeata SPC772; Pseudanabaena mucicola SPC782; Geitlerinema splendidum SPC923; Phormidium sp. SPC767; Rhabdoderma cocoide SPC766; Cylindrospermopsis raciborskii 339-T3 e Raphidiopsis brookii 338-T2) e duas da represa Guarapiranga (Planktothrix sp. NPRG1 e Microcystis protocystis SPC697). Todos esses organismos, incluindo àqueles isolados inicialmente através da metodologia descrita por Whitton (1996), são mantidos em meio de cultura líquido BG11 (Tabela 3, Allen,1968) ou ASM-1 (Tabela 4, Gorham et al., 1964), sob iluminação fluorescente constante de $30 \mu \mathrm{E} \cdot \mathrm{m}^{2} \mathrm{~s}^{-1}$ e temperatura controlada de $24 \pm 1^{\circ} \mathrm{C}$. Outras culturas de cianobactérias usadas neste estudo como controle positivo nos géis de DGGE são cultivadas no laboratório de Biologia Celular e Molecular do CENA/USP nas mesmas condições descritas acima (Tabela 5).

As fotos de cianobactérias apresentadas neste estudo foram obtidas em microscópio ótico Eclipse E800 (Nikon Instech Co., Ltd., Japan) acoplado a uma câmera fotográfica, localizado no Laboratório de Microbiologia Molecular, do Departamento de Solos e Nutrição de Plantas, da ESALQ/USP. 
Tabela 3. Meio de cultura BG-11 usado na manutenção das cianobactérias (Allen, 1968)

\begin{tabular}{lccc}
\hline \multicolumn{1}{c}{ Componentes } & $\begin{array}{c}\text { Estoque } \\
(\mathbf{g} / \mathbf{~} \mathbf{)}\end{array}$ & Usar por litro & Concentração final $(\mathbf{g} / \mathbf{L})$ \\
\hline & 150 & $10 \mathrm{ml}$ & 1,5 \\
1. $\mathrm{NaNO}_{3}$ & 40 & $1 \mathrm{ml}$ & 0,04 \\
2. $\mathrm{K}_{2} \mathrm{HPO}_{4}$ & 75 & $1 \mathrm{ml}$ & 0,075 \\
3. $\mathrm{MgSO}_{4} \cdot 7 \mathrm{H}_{2} \mathrm{O}$ & 36 & $1 \mathrm{ml}$ & 0,036 \\
4. $\mathrm{CaCl}_{2} .2 \mathrm{H}_{2} \mathrm{O}$ & 6 & $1 \mathrm{ml}$ & 0,006 \\
5. Ácido cítrico & 6 & $1 \mathrm{ml}$ & 0,006 \\
6. Citrato de amônio férrico & 1 & $1 \mathrm{ml}$ & 0,001 \\
7. Na EDTA & - & $1 \mathrm{ml}$ & - \\
8. Micronutrientes & 20 & $1 \mathrm{ml}$ & 0,02 \\
9. Carbonato de sódio & & & \\
\hline
\end{tabular}

10. Completar o volume com $\mathrm{H}_{2} \mathrm{O}$ deionizada para $1000 \mathrm{~mL}$

Autoclavar.

pH após autoclavagem e esfriamento: 7,4

\section{Notas:}

Se fizer aeração com $\mathrm{CO}_{2}$, deve-se adicionar $1 \mathrm{M}$ HEPES, pH 8,0 numa concentração final de 10 a $20 \mathrm{mM}$ (ou seja, 10 a $20 \mathrm{~mL}$ por litro).

Para meio sólido, adicione noble agar numa concentração final de $1 \%$.

\section{Solução de micronutrientes}

\begin{tabular}{|c|c|}
\hline $\mathrm{H}_{3} \mathrm{BO}_{3}$ & 2,86 \\
\hline $\mathrm{MnCl}_{2} \cdot 4 \mathrm{H}_{2} \mathrm{O}$ & 1,81 \\
\hline $\mathrm{ZnSO}_{4} \cdot 7 \mathrm{H}_{2} \mathrm{O}$ & 0,222 \\
\hline $\mathrm{Na}_{2} \mathrm{Mo}_{4} \cdot 2 \mathrm{H}_{2} \mathrm{O}$ & 0,39 \\
\hline $\mathrm{CuSO}_{4} \cdot 5 \mathrm{H}_{2} \mathrm{O}$ & 0,079 \\
\hline $\mathrm{Co}\left(\mathrm{NO}_{3}\right)_{2} \cdot 6 \mathrm{H}_{2} \mathrm{O}$ & 0,049 \\
\hline
\end{tabular}


Tabela 4. Meio de cultura ASM-1 usado na manutenção das cianobactérias (Gorham et al., 1964)

\begin{tabular}{lll}
\hline Solução estoque $\mathrm{A}$ & Peso $(\mathrm{g})$ & \\
\hline $\mathrm{NaNO}_{3}$ & 1,70 & Completar para $200 \mathrm{~mL}$ \\
$\mathrm{MgCl}_{2} \cdot 6 \mathrm{H}_{2} \mathrm{O}$ & 0,41 & \\
$\mathrm{MgSO}_{4} \cdot 7 \mathrm{H}_{2} \mathrm{O}$ & 0,49 & \\
$\mathrm{CaCl}_{2} \cdot 2 \mathrm{H}_{2} \mathrm{O}$ & 0,29 & \\
Solução estoque B & & \\
$\mathrm{K}_{2} \mathrm{HPO}_{4}$ ou & 0.87 & Completar para $100 \mathrm{~mL}$ \\
$\mathrm{~K}_{2} \mathrm{HPO}_{4} \cdot 3 \mathrm{H}_{2} \mathrm{O}$ & 1,14 & \\
$\mathrm{Na}_{2} \mathrm{HPO}_{4} \cdot 12 \mathrm{H}_{2} \mathrm{O}$ ou & 1,78 & \\
$\mathrm{Na}_{2} \mathrm{HPO}_{4} \cdot 7 \mathrm{H}_{2} \mathrm{O}$ & 1,33 & \\
$\mathrm{Solução} \mathrm{estoque} \mathrm{C}$ & & \\
$\mathrm{H}_{3} \mathrm{BO}_{3}$ & 2,48 & Completar para $100 \mathrm{~mL}$ \\
$\mathrm{MnCl}_{2} \cdot 4 \mathrm{H}_{2} \mathrm{O}$ & 1,39 & \\
$\mathrm{FeCl}_{3} \cdot 6 \mathrm{H}_{2} \mathrm{O}$ & 1,08 & \\
$\mathrm{ZnCl}_{2}$ & 0,335 & \\
$\mathrm{CoCl}_{2} \cdot 6 \mathrm{H}_{2} \mathrm{O}$ & 0,019 & \\
$\mathrm{CuCl}_{2}$ & 0,0014 & \\
Solução estoque D & & \\
EDTA.Na & & \\
\hline
\end{tabular}

Para cada litro de ASM-1:

Estoque A $\quad 20,0 \mathrm{~mL}$

Estoque $B \quad 2,0 \mathrm{~mL}$

Estoque C $\quad 0,1 \mathrm{~mL}$

Estoque $\mathrm{D} \quad 0,4 \mathrm{~mL}$

Completar para $1000 \mathrm{~mL}$. Ajustar o pH para 7,0 
Tabela 5. Cianobactérias utilizadas como controle nos estudos de DGGE.

Toxina produzida

$\begin{array}{ll}\text { Organismos } & \text { Fonte }\end{array}$

\section{Origem}

\begin{tabular}{llll}
\hline Microcystis aeruginosa & NPJB1 (UFR *) & $\begin{array}{l}\text { Lagoa das Garças, Parque Estadual das } \\
\text { Fontes do Ipiranga, São Paulo, SP, } \\
\text { Brasil }\end{array}$ & Microcistina (hepatotoxina) \\
\hline Microcystis aeruginosa & NPDC1 (UFR *) & Município do Rio de Janeiro, RJ & $\begin{array}{l}\text { Não produtora de } \\
\text { microcistina }\end{array}$ \\
\hline $\begin{array}{l}\text { Microcystis } \\
\text { panniformis }\end{array}$ & $\begin{array}{l}\text { SPC702 (Instituto de } \\
\text { Botânica, São Paulo, SP) }\end{array}$ & $\begin{array}{l}\text { Lagoa das Garças, Parque Estadual das } \\
\text { Fontes do Ipiranga, São Paulo, SP, } \\
\text { Brasil }\end{array}$ & Microcistina \\
\hline $\begin{array}{l}\text { Cylindrospermopsis } \\
\text { raciborskii }\end{array}$ & Botânica, São Paulo, SP) & Represa Billings, SP & Saxitoxina (neurotoxina) \\
\hline
\end{tabular}

* UFRJ - Universidade Federal do Rio de Janeiro, Rio de Janeiro, RJ. 


\subsection{Extração de DNA genômico de culturas puras de cianobactérias}

Para a extração de DNA genômico das culturas puras de cianobactérias usadas neste estudo, uma suspensão de $3 \mathrm{~mL}$ de células na fase de crescimento exponencial foi coletada e concentrada através de centrifugação a $13000 \times g$, durante 15 min. 0 sobrenadante foi descartado e do pélete contendo as células de cianobactérias foi feita a extração do DNA genômico, seguindo o método descrito por Fiore et al. (2000). Cinco microlitros $(5 \mu \mathrm{L})$ dos DNAs extraídos foram acrescidos de tampão de carregamento (ficol $15 \%$, azul de bromofenol $0,25 \%$, xilenocianol $0,25 \%$ ) e a integridade dos mesmos foi verificada em gel de agarose $1 \%$, contendo brometo de etídio $(0,3 \mu \mathrm{g} / \mathrm{mL}$ de gel), após corrida eletroforética em tampão 0,5 X TBE (1 X TBE: 45 mM Tris-borato, 1 mM EDTA, pH 8,0). A documentação do gel foi feita através do programa "Multi Analyst" do "Fluor-S ${ }^{T \mathrm{TM}}$ MultiImager" (BioRad, Hercules, California, E.U.A.). Como padrão de tamanho de DNA foi utilizado o marcador molecular Lambda DNA/EcoR I + Hind III (Promega, Madison, E.U.A.). O material foi armazenado a temperatura de $-20^{\circ} \mathrm{C}$ até $\mathrm{O}$ momento da próxima análise.

\subsection{Extração de DNA genômico de amostras ambientais de água}

As amostras ambientais de água armazenadas a temperatura de $-20^{\circ} \mathrm{C}$ foram descongeladas e 0 DNA foi extraído utilizando-se 0 kit FastDNA ${ }^{\circledR}$ da QBIOgene (Carlsbad, CA, E.U.A.) e matrizes de $1 / 4$ de polegada, de acordo com as recomendações do fabricante, conforme descrito a seguir. Aos microtubos contendo as matrizes de $1 / 4$ de polegada, adicionou-se $100 \mu \mathrm{L}$ das amostras ambientais e $1 \mathrm{~mL}$ de solução CLS - Y (solução de lise celular). Os tubos foram agitados, horizontalmente, por $10 \mathrm{~s}$ a $4 \mathrm{~m} \mathrm{~s}^{-1}$, em um homogeneizador FP120 FastPrep Cell Disruptor da QBIOgene. Em seguida, foram centrifugados por $5 \mathrm{~min}$ a $13000 \times \mathrm{g}$. $\mathrm{O}$ sobrenadante (apenas $600 \mu \mathrm{L}$ ) foi transferido para um microtubo novo e esterilizado. A essa solução adicionou-se $600 \mu \mathrm{L}$ da matriz de ligação, agitando-se gentilmente os microtubos durante $3 \mathrm{~min}$, por inversão. Os tubos foram incubados por $5 \mathrm{~min}$ a temperatura ambiente; posteriormente foram centrifugados durante $1 \mathrm{~min}$ a $13000 \times \mathrm{g}$, e o sobrenadante foi descartado. 0 pélete foi ressuspendido em $500 \mu \mathrm{L}$ de solução de lavagem (SEWS), centrifugado durante 1 min e o sobrenadante descartado. Centrifugou-se novamente durante $10 \mathrm{~s} \mathrm{a}$ 
$13000 \times$ g para remover o residual líquido. O DNA foi eluído da matrix de ligação através da adição de $100 \mu \mathrm{L}$ de água ultrapura (DES), incubando-se por $3 \mathrm{~min}$ a temperatura ambiente e centrifugando-se por $1 \mathrm{~min}$ a $13000 \times \mathrm{g}$, sendo recolhido em um microtubo novo e esterilizado. A integridade dos DNAs extraídos foi verificada conforme descrito acima.

\subsection{Análise da biodiversidade de cianobactérias por meio de DGGE}

\subsubsection{Amplificação do gene que codifica para o rRNA 16S}

Para a amplificação do gene de rRNA $16 \mathrm{~S}$ de cianobactérias das amostras ambientais de água, utilizou-se o seguinte conjunto de oligonucleotídeos iniciadores: 27F1 (5'-AGAGTTTGATCCTGGCTCAG-3') e 1494Rc (5'-TACGGCTACCTTGTTACGAC-3') (Neilan et al., 1997), confeccionado pela Invitrogen (Invitrogen, Carlsbad, California, USA). A amplificação foi feita em solução contendo: tampão para a reação PCR 1 X (20 $\mathrm{mM}$ Tris $\mathrm{HCl} \mathrm{pH} \mathrm{8,4;50} \mathrm{mM} \mathrm{KCl);} \mathrm{0,2} \mathrm{mM} \mathrm{de} \mathrm{cada} \mathrm{dNTP;} 3 \mathrm{mM} \mathrm{MgCl} 2 ; 1,5 \mathrm{U}$ de Platinum ${ }^{\circledR}$ Taq DNA Polimerase (Invitrogen); $10 \mathrm{ng}$ de DNA; 5 pmol de cada primer; água ultrapura (Milli-Q, Millipore, E.U.A.), esterilizada, para um volume final de $25 \mu \mathrm{L}$. A reação foi feita em um termociclador "Gene Amp PCR System 2400" (Applied Biosystems, Foster City, CA, E.U.A.), nas seguintes condições: $95^{\circ} \mathrm{C} / 3 \mathrm{~min} ; 30$ ciclos $94^{\circ} \mathrm{C} / 10 \mathrm{~s}, 50^{\circ} \mathrm{C} / 20 \mathrm{~s}, 72^{\circ} \mathrm{C} / 1 \mathrm{~min}$; extensão final a $72^{\circ} \mathrm{C} / 7 \mathrm{~min}$. A verificação do tamanho dos amplicons resultantes foi feita por comparação com o padrão de tamanho de DNA Lambda DNA/EcoR I + Hind III (Promega), após corrida eletroforética realizada nas mesmas condições descritas no item 3.3.

Os amplicons resultantes dessa amplificação foram utilizados como molde para uma nova amplificação realizada com o seguinte conjunto de iniciadores: CYA359F (5'GGGGAATYTTCCGCAATGGG-3', Y= C/T) e CYA781R (obtido através de mistura equimolar entre: CYA781R (a) - 5'-GACTACTGGGGTATCTAATCCCATT-3' e CYA781R (b) 5'-GACTACAGGGGTATCTAATCCCTTT-3') (Nübel et al., 1997). O iniciador CYA359F também foi usado como não degenerado, ou seja, confeccionado substituindo o $\mathrm{Y}$ por T, e foi chamado de CYA359F1 (5'-GGGGAATTTTCCGCAATGGG-3'). Nesses dois iniciadores (degenerado ou não) foi acrescentado em suas extremidades $5^{\prime}$ um "clamp" 
rico em GC (CGCCCGCCGCGCCCCGCGCCGGTCCCGCCGCCCCCGCCCG), necessário para a separação dos amplicons por DGGE (eletroforese em gel com gradiente desnaturante). A amplificação foi feita em solução contendo: tampão para a reação PCR 1 X (20 mM Tris $\mathrm{HCl} \mathrm{pH} \mathrm{8,4;} 50 \mathrm{mM} \mathrm{KCl}$ ); 0,2 mM de cada dNTP; 3,5 mM MgCl ; 1,5 U de Platinum ${ }^{\circledR}$ Taq DNA Polimerase (Invitrogen); $10 \mathrm{ng}$ de DNA; 5 pmol de cada primer; $0,5 \mu \mathrm{L}$ de formamida, água ultrapura, esterilizada, para um volume final de 25 $\mu \mathrm{L}$. A reação ocorreu no mesmo termociclador usado anteriormente, nas seguintes condições: $94^{\circ} \mathrm{C} / 5 \mathrm{~min} ; 35$ ciclos $94^{\circ} \mathrm{C} / 1 \mathrm{~min}, 63^{\circ} \mathrm{C} / 1 \mathrm{~min}, 72^{\circ} \mathrm{C} / 1 \mathrm{~min}$; extensão final a $72^{\circ} \mathrm{C} / 7 \mathrm{~min}$. Culturas puras de Microcystis aeruginosa NPJB1 (Azevedo et al., 1994), Microcystis aeruginosa NPDC1, Microcystis panniformis SPC702 (Komárek et al., 2002) e Cilindrospermopsis raciborskii 339-T3 (Lagos et al., 1999) foram utilizadas como controle positivo (Tabela 5). A quantificação dos amplicons resultantes foi feita em gel de agarose $1 \%$, conforme descrito no item 3.3, utilizando-se como padrão de tamanho e massa molecular o marcador Low DNA Mass Ladder (Invitrogen).

\subsubsection{Utilização de DGGE com amplicons do gene de rRNA 16S}

Os diversos amplicons obtidos na PCR do gene de rRNA 16S, representando genótipos de cianobactérias com diferentes concentrações de GC, foram separados por DGGE. Os géis, $6 \%$ acrilamida:bisacrilamida $(37,5: 1 ; \mathrm{m}: \mathrm{m})$, conforme os melhores resultados obtidos em experimentos preliminares, foram preparados com gradiente desnaturante variando de 15 a 35\%, utilizando duas soluções: uma solução $100 \%$ desnaturante, contendo uréia $7 \mathrm{M}$ e formamida $40 \%$ (vol/vol), e uma solução $0 \%$, sem uréia e sem formamida (Øvreås et al., 1997). A eletroforese foi realizada a $60^{\circ} \mathrm{C} / 180 \mathrm{~V}$ constantes, durante $6 \mathrm{~h}$, no sistema de eletroforese vertical DC-Code (BioRad, Hercules, California, E.U.A.), em géis de $16 \times 16 \times 0,1 \mathrm{~cm}$ e solução tampão TAE 0,5 X (1 X TAE: $40 \mathrm{mM}$ Tris-acetato e $1 \mathrm{mM}$ EDTA pH 8,0). Foram aplicados $500 \mathrm{ng}$ de produto de PCR por canaleta (Nübel et al., 1999). Após a eletroforese, os géis foram fixados em solução de ácido acético glacial $10 \%$ por 15 min. Em seguida, foram lavados três vezes com água destilada, imersos em solução de metanol $50 \%$ por 15 min, lavados três vezes com água destilada novamente e corados em solução de SYBRGreen I $(0,1 \mu \mathrm{g} / \mathrm{mL})$ (Molecular Probe, Eugene, Oregon, E.U.A.) por 30 min. Após a 
coloração, os géis contendo as bandas de DNA foram analisados por densitometria, utilizando-se um densitômetro laser FluorImage (Molecular Dynamics, Sunnyvale, California, E.U.A.) e o programa Fragment Analyses (Molecular Dynamics).

\subsubsection{Excisão dos amplicons a partir do gel de poliacrilamida}

Bandas de interesse obtidas após DGGE foram selecionadas e excisadas do gel com lâmina de bisturi cirúrgico esterilizada. Elas foram eluídas em $20 \mu \mathrm{L}$ de água ultrapura, esterilizada, por aproximadamente 16 horas a $4^{\circ} \mathrm{C}$. Depois de centrifugadas por $1 \mathrm{~min}, 2 \mu \mathrm{L}$ do DNA eluído de cada banda de DGGE foram reamplificados seguindo as condições já descritas (item 3.5.1), excetuando-se o fato de que o iniciador CYA359F foi utilizado sem o "clamp" na extremidade 5 ', necessário apenas para a separação dos amplicons na DGGE. Uma alíquota $(5 \mu \mathrm{L})$ foi analisada através de eletroforese em gel de agarose a 1,0\% - 0,5X TBE e o DNA foi visualizado de acordo com as mesmas condições descritas no item 3.3. Em seguida, alíquotas de $30 \mu \mathrm{L}$ dos produtos amplificados foram aplicadas em um gel de agarose "Low Melting Point" (Invitrogen) a $1 \%$, contendo brometo de etídio $(0,3 \mu \mathrm{g} / \mathrm{mL}$ de gel), e submetidos a corrida eletroforética em tampão TBE $0,5 \mathrm{X}$, a $75 \mathrm{~V}$, durante $1 \mathrm{~h} 30 \mathrm{~min}$. Os amplicons foram mais uma vez excisados do gel, purificados utilizando-se o "GFX" ${ }^{T M}$ PCR DNA and Gel Band Purification Kit" (Amersham Biosciences, Piscataway, New Jersey, E.U.A.), segundo as recomendações do fabricante, e seqüenciados.

\subsubsection{Sequenciamento de amplicons do gene de rRNA 16S}

As seqüências de DNA eluídas de cada banda de DGGE e purificadas foram reamplificadas por PCR usando o kit "Big Dye ${ }^{\circledR}$ Terminator v3.1. Cycle Sequencing" (cat. No. 4337455, Applied Biosystems). A reação de PCR utilizada é descrita a seguir. Os fragmentos de interesse (10-40 $\mathrm{ng}$ ) foram colocados em microtubos onde foram adicionados 5 pmol do iniciador CYA359F (sem o clamp GC) ou CYA781R, 1,5 $\mathrm{LL}$ de "Big Dye", 2,0 $\mu \mathrm{L}$ de tampão $5 \times$ Sequencing e água ultrapura para um volume final de $10 \mu \mathrm{L}$. As condições de amplificação foram as mesmas descritas no item 3.5.1, para o conjunto de iniciadores CYA359F/CYA781R. Após a amplificação dos fragmentos de interesse, procedeu-se a precipitação dos mesmos. Os produtos de PCR obtidos foram 
transferidos para tubos de $500 \mu \mathrm{L}$, onde $10 \mu \mathrm{L}$ de água ultrapura esterilizada e $30 \mu \mathrm{L}$ de isopropanol $100 \%$ foram adicionados. Após misturá-los usando vortex, os tubos foram incubados a temperatura de $25^{\circ} \mathrm{C}$ por 15 min e centrifugados a $10.000 \times g$ por 20 min na mesma temperatura. O sobrenadante foi descartado e $250 \mu \mathrm{L}$ de etanol $70 \%$ foi adicionado. A mistura foi feita em vortex. Após centrifugação (10.000 x $g$ por $5 \mathrm{~min}$ a $25^{\circ} \mathrm{C}$ ), o sobrenadante foi descartado e o pélete foi seco a $40^{\circ} \mathrm{C}$ por $5 \mathrm{~min}$. Em seguida, o pélete foi ressuspendido em $10 \mu \mathrm{L}$ de tampão de corrida (HiDi formamida), transferido para microplacas com capacidade para 96 amostras e incubado a temperatura de $4^{\circ} \mathrm{C}$ por $10 \mathrm{~min}$. Essa placa foi colocada em um termociclador onde fezse a desnaturação do DNA a $96^{\circ} \mathrm{C}$ durante 5 min, sendo então colocada no gelo imediatamente após. Posteriormente, ela foi inserida no seqüenciador capilar ABI PRISM $^{\circledR} 3100$ Genetic Analyzer (Applied Biosystems), pertencente ao laboratório de Biologia Celular e Molecular, do CENA/USP, para o sequenciamento dos fragmentos de DNA por aproximadamente 2,5 horas. Os dados gerados pelo seqüenciador foram coletados e processados pelo programa "ABI PRISM" ${ }^{\circledR}$ DNA Sequencing - Analysis Sofware" versão 3.7 (Applied Biosystems).

\subsubsection{Processamento e análise filogenética das seqüências}

As seqüências geradas foram processadas para remoção de bases produzidas com baixa qualidade (índice de qualidade < 20) através do pacote que contém os programas Phred/Phrap/Consed (Ewing \& Green, 1998; Ewing et al., 1998; Gordon et al., 1998), em sistema operacional Linux.

Posteriormente, foram comparadas com outras seqüências previamente depositadas no Ribosomal Database Project II (RDP) (Maidak et al., 1999) e/ou no GenBank do National Center for Biotechnology Information (NCBI), utilizando-se a ferramenta Basic Local Alignment Search Tool (BLAST) (Altschul et al., 1990), visando a identificação das espécies de cianobactérias.

No alinhamento seqüencial múltiplo dos genes de rRNA 165 obtidos neste estudo, e outros selecionados nos bancos de dados públicos, foi usado o programa Clustal W 1.8 (Thompson et al., 1994). O ajuste das extremidades das seqüências de DNA, de forma que todas elas tivessem o mesmo número de bases e estivessem 
completamente alinhadas, foi feito com o auxílio do programa BioEdit (Hall, 2001). No cálculo da significância estatística da similaridade entre as seqüências foi usada a análise de reamostragem ("bootstrap") (Swofford et. al., 1996) para 1000 replicações. O método de distância ("Neighbour Joining") (Saitou \& Nei, 1987) foi usado na construção da árovre filogenética. A visualização gráfica das árvores construídas foi observada por meio do programa TreeView (Page, 2001).

\subsection{Análise da biodiversidade de cianobactérias por meio da construção de mini-bibliotecas}

\subsubsection{Mini-biblioteca de amplicons do gene de rRNA 16S}

O DNA usado neste estudo foi extraído de uma amostra ambiental de água coletada no reservatório Billings, Braço do Taquacetuba, na linha de transmissão (amostra 98481, Tabela 1), a qual foi escolhida por apresentar teores de microcistina bastante altos $(23,49 \mu \mathrm{g} / \mathrm{L})$.

\subsubsection{Amplificação do gene de rRNA 16S}

A amplificação do gene que codifica para o rRNA 16S de cianobactérias para a construção da mini-bliblioteca foi realizada da mesma maneira descrita no item 3.5.1., utilizando-se os oligonucleotídeos iniciadores de PCR 27F1/1494Rc (Neilan et al., 1997).

\subsubsection{Construção da mini-biblioteca}

Três reações de amplificação do gene de rRNA 16S feitas separadamente foram posteriormente misturadas, visando minimizar eventuais problemas, às vezes, gerados pela técnica de PCR, tal como somente amplicons resultantes do microrganismo mais dominante.

Clonagem. Na clonagem das seqüências de rRNA 16S produzidas na PCR, utilizou-se o kit de clonagem "TOPO TA Cloning" fabricado pela Invitrogen. O vetor usado foi o $\mathrm{pCR}^{\circledR}$ 2.1-TOPO ${ }^{\circledR} \quad$ (originário do pUC), que é oferecido linearizado com uma Topoisomerase I covalentemente ligada ao vetor, o que aumenta a eficiência de 
ligação. Esse vetor contém sítios para resistência a ampicilina e kanamicina, um sítio para múltipla clonagem, um fragmento do $L a c Z \alpha$ e sítios para os primers T7 promoter e M13 reverse e M13 forward. Os insertos foram purificados usando o "GFX'M PCR DNA and Gel Band Purification Kit" (Amersham Biosciences), e a clonagem no vetor foi feita seguindo as instruções do fabricante, presentes no Manual de Instrução do TOPO TA Cloning ${ }^{\circledR}$.

Preparo de células competentes de E. coli. A bactéria E. coli $\mathrm{DH} 5 \alpha$ foi utilizada como recipiente. As células competentes de $E$. coli $\mathrm{DH} 5 \alpha$ foram preparadas quimicamente usando o método de cloreto de cálcio (Sambrook et al., 1989). Células de uma colônia isolada de $E$. coli, crescidas em placa contendo meio LB, foram inoculadas em um erlenmeyer de $50 \mathrm{~mL}$ contendo $10 \mathrm{~mL}$ de meio LB líquido, sendo este incubado a $37^{\circ} \mathrm{C}$, por $14-16$ horas, sob agitação constante de $200 \mathrm{rpm}$ (New Brunswick Scientific - C24 Incubator Shaker, Edison NJ, USA). Num erlenmeyer de 250 $\mathrm{mL}$ contendo $25 \mathrm{~mL}$ de meio LB líquido foram inoculados $100 \mu \mathrm{L}$ da cultura crescida durante a noite. $\mathrm{O}$ frasco foi então incubado a $37^{\circ} \mathrm{C}$ por aproximadamente 3 horas, sob agitação constante de $200 \mathrm{rpm}$, para uma absorbância de 0,5 a $600 \mathrm{~nm}$. As células foram transferidas para tubos de centrífuga esterilizados de $50 \mathrm{~mL}$ e colocadas no gelo durante 10 minutos, sendo em seguida coletadas por centrifugação a $4.000 \times g$, por 5 minutos, a $15^{\circ} \mathrm{C}$. Após descartar o sobrenadante, as células foram gentilmente ressuspendidas em $1 / 2$ volume de uma solução gelada e esterilizada de $\mathrm{CaCl}_{2} /$ glicerol (50 mM de $\mathrm{CaCl}_{2}$ e $10 \%$ glicerol). Os tubos foram deixados no gelo durante 15 minutos e então centrifugados como antes. As células foram gentilmente ressuspendidas em 1/5 do volume da solução gelada de $\mathrm{CaCl}_{2} /$ glicerol, aliquotadas ( $\sim 50 \mu \mathrm{L}$ ) em microtubos de $1,5 \mathrm{~mL}$ (mantidos no gelo) e armazenadas a $-80^{\circ} \mathrm{C}$.

Transformação. A introdução do vetor contendo o inserto nas células competentes de E. coli $\mathrm{DH} 5 \alpha$ foi feita através de choque térmico (Sambrook et al., 1989). Dois microlitros $(2 \mu \mathrm{L})$ do produto de ligação e $50 \mu \mathrm{L}$ de suspensão de células competentes de $E$. coli $\mathrm{DH} 5 \alpha$ foram misturados em um microtubo esterilizado, o qual foi incubado no gelo durante 30 minutos. 0 microtubo foi então transferido imediatamente para banho- 
maria a $42^{\circ} \mathrm{C}$ e deixado por 30 segundos, sem agitar. Posteriormente, adicionou-se a ele $250 \mu \mathrm{L}$ de meio SOC (Sambrook et al., 1989) a temperatura ambiente e, em seguida, este foi incubado a $37^{\circ} \mathrm{C}$, durante 1 hora, sob agitação de $180-200 \mathrm{rpm}$. As células competentes transformadas foram plaqueadas em meio LB sólido contendo ampicilina e X-Gal, ambos em concentrações finais de $100 \mu \mathrm{g} \mathrm{mL}^{-1}$ de meio. As placas foram incubadas por $14-16$ horas, a temperatura de $37^{\circ} \mathrm{C}$.

PCR usando colônias. Após o plaqueamento em meio de cultivo LB contendo ampicilina e X-Gal, 100 colônias de transformantes foram utilizadas para novas reações de PCR, visando confirmar a presença dos insertos de interesse. Uma pequena quantidade de células de cada clone transformado foi adicionada a $25 \mu \mathrm{L}$ de reação de PCR (conforme descrito no item 3.5.1), contendo os inciadores 27F1/1494Rc para a amplificação do inserto. $O$ tamanho dos fragmentos amplificados foi verificado em gel de agarose 1\%-0,5X TBE, conforme descrito no item 3.3. Clones não amplificados foram desconsiderados.

Polimorfismo nos fragmentos de restrição do DNA (RFLP). Os clones contendo insertos com diferentes seqüências do gene rRNA de $16 \mathrm{~S}$ foram identificados através de RFLP. Os produtos de PCR, obtidos na amplificação do gene rRNA de $16 \mathrm{~S}$ usando DNAs inseridos nos clones, foram digeridos com $1 \mathrm{U}$ da enzima de restrição Hae III (Invitrogen), durante 2 horas a $37^{\circ} \mathrm{C}$. Os fragmentos de DNA obtidos nessa digestão foram separados através de eletroforese em gel de agarose 3.0\%-0,5X TBE, durante 4 horas, a 55V. Após identificar visualmente os diferentes padrões de RFLP obtidos, os clones foram selecionados para sequenciamento.

Extração de DNA plasmidial. A extração de plasmídeos das células de $E$. coli $\mathrm{DH} 5 \alpha$ que continham os insertos com padrões diferentes de bandas, identificados por RFLP, foi feita pelo método de preparação de pequena escala de plasmídeo, usando hidrólise alcalina, de acordo com Birnboim \& Doly (1979). As colônias brancas que fizeram parte da seleção foram transferidas para $5 \mathrm{~mL}$ de meio LB contendo ampicilina e cultivadas por 14-16 horas, a $37^{\circ} \mathrm{C}$, sob agitação de $150 \mathrm{rpm}$. Em microtubos de $1,5 \mathrm{~mL}$ foram 
colocados 1,5 mL da cultura de células produzida e, em seguida, estas foram centrifugadas a $10.000 \times g$ por 20 segundos. 0 mesmo procedimento foi repetido mais uma vez. O pélete formado foi ressuspendido em $100 \mu \mathrm{L}$ de solução I gelada (Tris-HCl 25 mM, pH 8,0, EDTA 10 mM e glucose 50 mM). Duzentos $\mu \mathrm{L}(200 \mu \mathrm{L})$ de solução II $(\mathrm{NaOH} 0,2 \mathrm{~N}, \mathrm{SDS} 1 \%)$ foram acrescentados e misturados gentilmente através da inversão dos microtubos. Após terem sido incubados no gelo por 5 minutos, foram adicionados aos microtubos $150 \mu \mathrm{L}$ de solução III gelada (acetato de potássio $3 \mathrm{M} \mathrm{e}$ ácido fórmico 1,8 M). Procedeu-se novamente a mistura por inversão e os microtubos foram incubados no gelo por mais 5 minutos. Posteriormente, foram centrifugados a $10.000 \times g$ durante 7 minutos e o sobrenadante foi transferido para um novo tubo. Adicionou-se $6 / 10$ do volume $(\sim 270 \mu \mathrm{L})$ de isopropanol a temperatura ambiente, misturando-se e centrifugando-se conforme descrito anteriormente. Após a eliminação do sobrenadante, o pélete foi lavado uma vez com $250 \mu \mathrm{l}$ de etanol $70 \%$ gelado e centrifugado a $10.000 \times g$ por 2 minutos. $O$ pélete foi então seco e ressuspendido em $30 \mu \mathrm{L}$ de uma solução contendo Tris-HCl $10 \mathrm{mM}$, pH 8,0, EDTA 0,5 M e $10 \mathrm{mg}$ RNAse/mL. Incubou-se essa mistura a $37^{\circ} \mathrm{C}$ por 30 minutos, centrifugou-a por 3 minutos para a remoção de materiais insolúveis e transferiu-se o sobrenadante para um microtubo novo e esterilizado. Os plasmídeos assim extraídos foram armazenados a $-20^{\circ} \mathrm{C}$ até a próxima etapa.

Sequenciamento. A PCR para o sequenciamento dos fragmentos inseridos nos plasmídeos foi feita usando-se o kit "Big Dye ${ }^{\circledR}$ Terminator v3.1. Cycle Sequencing", conforme descrito no item 3.5.4. Os oligonucleotídeos iniciadores utilizados foram o 27F1 ou o 1494Rc (Neilan et al., 1997), além de outros três conjuntos de primers (357F, 357R, 704F, 704R, 1114F, 1114R), visando o fechamento interno da seqüência de rRNA 16S. As condições de amplificação para os iniciadores 27F1/1494Rc foram as mesmas descritas no item 3.5.1, enquanto que para os demais iniciadores elas encontram-se a seguir: $94^{\circ} \mathrm{C} / 4 \mathrm{~min} ; 30$ ciclos $94^{\circ} \mathrm{C} / 1 \mathrm{~min}, 55^{\circ} \mathrm{C} / 30 \mathrm{~s}, 72^{\circ} \mathrm{C} / 2 \mathrm{~min}$; extensão final a $72^{\circ} \mathrm{C} / 10 \mathrm{~min}$. As demais etapas seguidas para o sequenciamento são as mesmas realizadas anteriormente e a forma de análise das seqüências obtidas está descrita no item 3.5.5. 


\subsubsection{Mini-biblioteca de amplicons da região do PC-IGS}

A amostra ambiental de água utilizada neste estudo foi a mesma usada na construção da mini-biblioteca do gene de rRNA 16S.

\subsubsection{Amplificação da região do PC-IGS}

Para a amplificação das seqüências do PC-IGS existentes no DNA extraído da amostra ambiental, utilizou-se o seguinte conjunto de oligonucleotídeos iniciadores: PCBF (5'-GGCTGCTTGTTTACGCGACA-3') e PCaR (5'-CCAGTACCACCAGCAACTAA-3') (Neilan et al., 1995). A amplificação foi feita em solução contendo: tampão para a reação PCR 1 X (20 mM Tris $\mathrm{HCl} \mathrm{pH} \mathrm{8,4;} 50 \mathrm{mM} \mathrm{KCl);0,2} \mathrm{mM} \mathrm{dNTP;} \mathrm{3,5} \mathrm{mM} \mathrm{MgCl} ; 1,5$ $\mathrm{U}$ de Platinum ${ }^{\circledR}$ Taq DNA Polimerase (Invitrogen); $20 \mathrm{ng}$ de DNA; 5 pmol de cada primer; água ultrapura, esterilizada, para um volume final de $25 \mu \mathrm{L}$. A reação foi realizada no mesmo termociclador usado anteriormente, nas seguintes condições: $92^{\circ} \mathrm{C} / 2 \mathrm{~min} ; 40$ ciclos $92^{\circ} \mathrm{C} / 40 \mathrm{~s}, 55^{\circ} \mathrm{C} / 50 \mathrm{~s}, 72^{\circ} \mathrm{C} / 2 \mathrm{~min}$; extensão final a $72^{\circ} \mathrm{C} / 8 \mathrm{~min}$. A verificação do tamanho e quantificação dos amplicons resultantes foi feita nas mesmas condições descritas no item 3.3, utilizando-se como padrão o marcador de massa molecular Low DNA Mass Ladder (Invitrogen).

\subsubsection{Construção da mini-biblioteca}

A construção de uma mini-biblioteca de seqüências do espaço intergênico da ficicianina foi realizada usando os mesmos procedimentos descritos no item 3.6.1.2.

Os produtos de amplificação de 300 clones também foram selecionados através de RFLP, pela digestão realizada com $1 \mathrm{U}$ de enzima de restrição $A / u$ I (Invitrogen), nas mesmas condições citadas anteriormente.

O sequenciamento foi feito seguindo-se os mesmos procedimentos descritos no item 3.5.4, com exceção dos iniciadores de PCR, que foram M13r (5'CAGGAAACAGCTATGAC-3') e T7 promoter (5'-TAATACGACTCACTATAGGG-3'). As condições de amplificação nesse caso foram: 1 ciclo de $92^{\circ} \mathrm{C} / 2$ min e 25 ciclos de $96^{\circ} \mathrm{C} / 10 \mathrm{~s}, 50^{\circ} \mathrm{C} / 5 \mathrm{~s}, 60^{\circ} \mathrm{C} / 4 \mathrm{~min}$. A análise das seqüências obtidas foi realizada conforme o item 3.5.5. 


\subsection{Detecção do domínio $\mathrm{N}$-metiltransferase do gene mcyA}

\subsubsection{Amplificação do domínio $\boldsymbol{N}$-metiltransferase do gene mcyA}

Os DNAs extraídos de treze linhagens de cianobactérias isoladas da Billings e da Guarapiranga (citadas no item 3.2) foram usados na amplificação do domínio $N$ metiltransferase (NMT) do $m c y A$, empregando o conjunto de oligonucleotídeos iniciadores: MSF (5'-ATCCAGCAGTTGAGCAAGC-3') e MSR (5'-TGCAGATAACTCC GCAGTTG-3') (Tillett et al., 2001). A amplificação foi feita em solução contendo: tampão para a reação PCR 1 X (20 mM Tris $\mathrm{HCl} \mathrm{pH} \mathrm{8,4;} 50 \mathrm{mM} \mathrm{KCl}) ; 0,2 \mathrm{mM}$ dNTP; 3 $\mathrm{mM} \mathrm{MgCl} ; 1,5 \mathrm{U}$ de Platinum ${ }^{\circledR}$ Taq DNA Polimerase (Invitrogen); $10 \mathrm{ng}$ de DNA; 5 pmol de cada primer; água ultrapura, esterilizada, para um volume final de $25 \mu \mathrm{L}$. A reação foi feita no mesmo termociclador até então utilizado, nas seguintes condições: $94{ }^{\circ} \mathrm{C} / 4 \mathrm{~min} ; 30$ ciclos $94^{\circ} \mathrm{C} / 10 \mathrm{~s}, 60^{\circ} \mathrm{C} / 20 \mathrm{~s}, 72^{\circ} \mathrm{C} / 1 \mathrm{~min}$; extensão final a $72^{\circ} \mathrm{C} / 7 \mathrm{~min}$. Culturas puras de Microcystis aeruginosa NPJB1 (Azevedo et al., 1994) e Microcystis panniformis SPC702 (Komárek et al., 2002) foram utilizadas como controle positivo (Tabela 5). Como padrão de tamanho de DNA foi utilizado o marcador molecular Lambda DNA/EcoR I + Hind III (Promega). A integridade dos produtos amplificados foi verificada em gel de agarose $1 \%$, conforme descrito anteriormente no item 3.3.

No presente estudo, também foi desenvolvido e testado um outro conjunto de oligonucleotídeos iniciadores (OMETF: 5'-TTATTCCAAGTTGCTCCCCA-3' e OMETR: 5'GGAAATACTGCACAACCGAG-3'), o qual tem como alvo uma pequena seqüência bastante variável do domínio NMT do mcyA. Os treze isolados testados com os oligonucleotídeos iniciadores MSF/MSR, assim como àqueles tomados como controle positivo, foram novamente utilizados. A amplificação foi feita em solução contendo: tampão para a reação PCR 1 X (20 mM Tris $\mathrm{HCl} \mathrm{pH} \mathrm{8,4;} 50 \mathrm{mM} \mathrm{KCl}$ ); 0,2 mM dNTP; 3,5 $\mathrm{mM} \mathrm{MgCl}_{2} ; 1,5 \mathrm{U}$ de Platinum ${ }^{\circledR}$ Taq DNA Polimerase (Invitrogen); $20 \mathrm{ng}$ de DNA; 5 pmol de cada primer; água ultrapura, esterilizada, para um volume final de $25 \mu \mathrm{L}$. A reação foi realizada no mesmo termociclador já descrito, nas seguintes condições: $94^{\circ} \mathrm{C} / 4 \mathrm{~min} ; 30$ ciclos $94^{\circ} \mathrm{C} / 20 \mathrm{~s}, 55^{\circ} \mathrm{C} / 30 \mathrm{~s}, 72^{\circ} \mathrm{C} / 1 \mathrm{~min}$; extensão final a $72^{\circ} \mathrm{C} / 7 \mathrm{~min}$. Para a verificação do tamanho e quantificação de DNA foi utilizado o marcador de 
massa molecular Low DNA Mass Ladder (Invitrogen). A integridade dos produtos amplificados foi verificada em gel de agarose $1 \%$, conforme descrito no item 3.3 .

\subsubsection{Sequenciamento do fragmento do domínio NMT do gene mcyA}

Os procedimentos para a clonagem e o sequenciamento do fragmento do domínio NMT do mcyA das espécies isoladas de cianobactérias são os mesmos descritos no item 3.6.1.2. Os iniciadores de PCR utilizados no sequenciamento foram o M13r/T7 promoter, conforme citado no item 3.6.2.2, e a análise das seqüências obtidas segue conforme descrito no item 3.5.5. 


\section{RESULTADOS E DISCUSSÃO}

\subsection{I solamento e cultivo de cianobactérias}

$\mathrm{O}$ isolamento de algumas cianobactérias presentes nas amostras de água coletadas nas represas Billings e Guarapiranga foi realizado com sucesso usando a metodologia descrita por Whitton (1996). Os gêneros Microcystis sp., Pseudanabaena sp. e Limnothrix sp. foram isolados e purificados. Outros gêneros e/ou espécies também foram observados crescendo nos meios de culturas utilizados, mas ainda não foram devidamente purificadas e identificadas (Figuras 3A, 3B e 3C). As cianobactérias são microrganismos de crescimento lento e tempo de geração variando de 12 a 50 horas é comum (Rippka et al., 1981). Assim, a purificação de algumas espécies pode durar de semanas a vários meses, isto sem contar o tempo inicial necessário para que ocorra a adaptação das espécies às novas condições de crescimento. Embora algumas das linhagens isoladas estejam praticamente puras atualmente, não foi possível utilizálas devido ao tempo exigido para separar os diferentes gêneros e/ou espécies.

No isolamento e purificação de cianobactérias das represas Billings e Guarapiranga realizados por outros autores (Lagos et al., 1999; Sant'Anna e Azevedo, 2000; Souza et al., 1998) foram obtidas as seguintes espécies: Aphanocapsa incerta, Microcystis aeruginosa, Anabaena planctonica, A. solitaria, A. spiroides, Cylindrospermopsis raciborskii, Raphidiopsis mediterranea, Oscillatoria agardhii, 0. quadripunctulata, O. amphibia, Lyngbya limnetica e Pseudanabaena catenata.

Diante da dificuldade em se obter culturas puras de cianobactérias isoladas das represas Billings e Guarapiranga em tempo hábil para utilização neste estudo, optou-se por utilizar linhagens já purificadas de ambas as represas existentes em coleções de culturas de cianobactérias do Instituto de Botânica de São Paulo e da Universidade Federal do Rio de Janeiro. Fotos de três dessas linhagens, Microcystis aeruginosa SPC777 (Instituto de Botânica-SPC), Microcystis aeruginosa NPJB1 (Azevedo et al., 


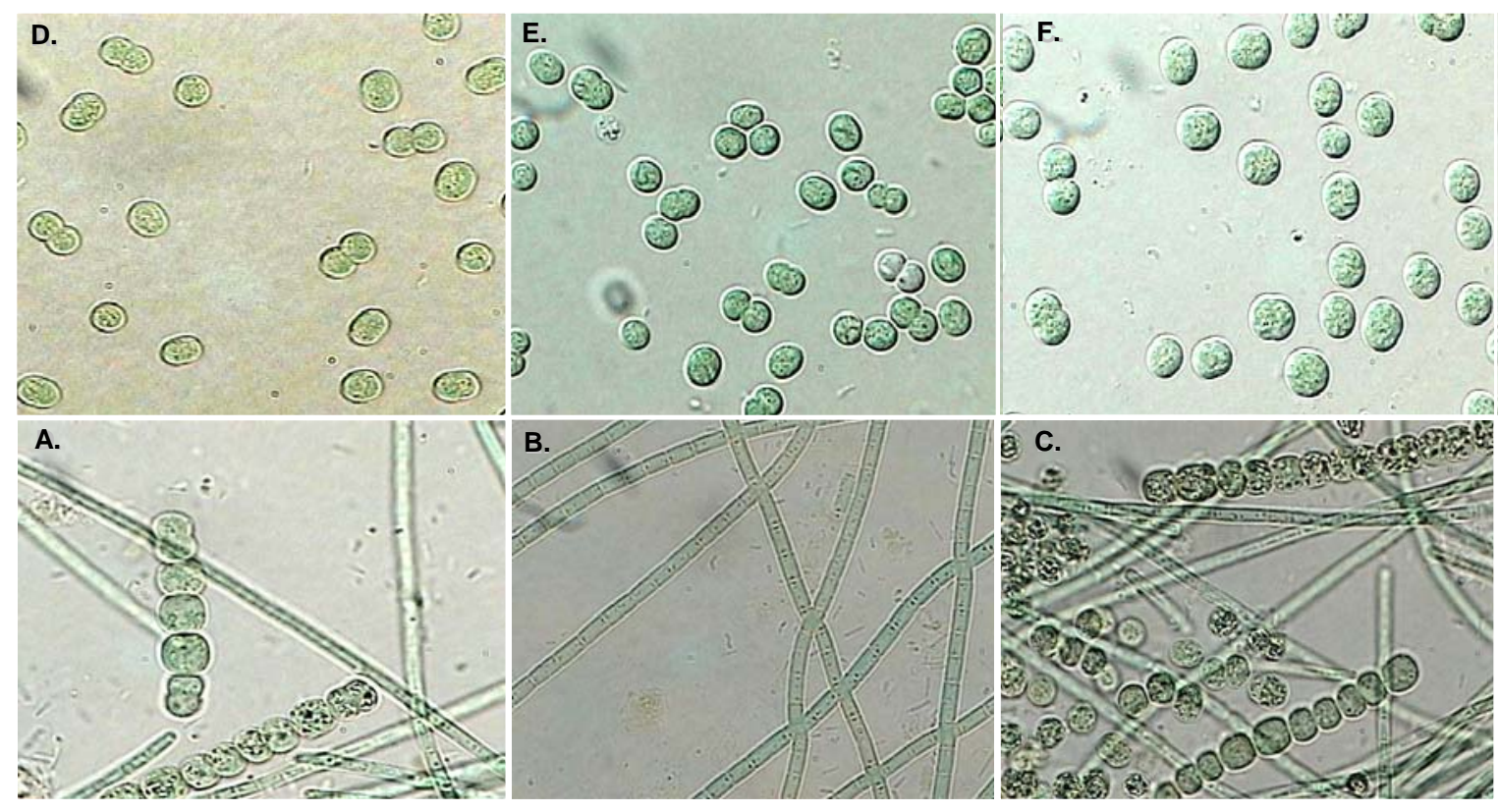

Figura 3 - Algumas das cianobactérias usadas neste estudo, em aumento de 1000x. A., B. e C. Misturas de vários gêneros de cianobactérias encontrados nas amostras de água coletadas na represa Billings-SP; D. Microcystis aeruginosa SPC777; E. Microcystis aeruginosa NPJB1; F. Microcystis panniformis SPC702. 
1994) e Microcystis panniformis SPC702 (Komárek et al., 2002), podem ser vistas nas Figuras 3D, 3E e 3F, respectivamente.

\subsection{Extração de DNA genômico de culturas puras de cianobactérias e de amostras ambientais de água}

As extrações de DNA genômico das culturas puras de cianobactérias foram realizadas com sucesso (Figura 4), usando o protocolo descrito por Fiore et al. (2000), que foi desenvolvido visando a obtenção de DNA de todos os gêneros deste grupo de organismos conhecidos até o momento. Entretanto, para as extrações de DNA das amostras ambientais de água, devido à presença de células eucarióticas, diferentes tipos de partículas, substâncias húmicas, etc., foi necessária a utilização de outra metodologia. Após testar várias metodologias disponíveis, obteve-se DNA de boa qualidade usando o kit FastDNA ${ }^{\circledR}$ da QBIOgene, conforme pode ser observado na Figura 5. Entretanto, somente foi possível obter DNA de todas as amostras e de boa qualidade com esse kit de extração, quando as etapas preliminares introduzidas foram utilizadas, ou seja, filtração da água, concentração das células por centrifugação e lavagens sucessivas do pélete com água ultrapura esterilizada.

A boa qualidade dos DNAs extraídos foi comprovada pelos eficientes resultados alcançados com a amplificação por PCR das diferentes seqüências de genes (rRNA 16S, PC-IGS e mcyA) usadas no estudo, conforme mostrados a seguir.

\subsection{Análise da biodiversidade de cianobactérias por meio de DGGE}

O conjunto de iniciadores específicos para a seqüência do gene de rRNA 165 de cianobactérias, CYA359F/CYA781R (Nübel et al., 1997), foi utilizado para a realização desse estudo. Inicialmente, várias tentativas para a amplificação dessa seqüência foram feitas sem sucesso. Assim, optou-se por fazer um "nested" PCR usando primeiramente os iniciadores 27F1/1494Rc (Neilan et al., 1997), que amplificaram as seqüências completas do gene de rRNA $16 \mathrm{~S}$ das cianobactérias presentes nas amostras ambientais de água. A partir dos amplicons gerados, novas amplificações foram feitas usando os iniciadores CYA359F/CYA781R. O iniciador CYA359F (Nübel et al., 1997) possui seqüência degenerada. No entanto, no presente estudo, além desse iniciador, uma 


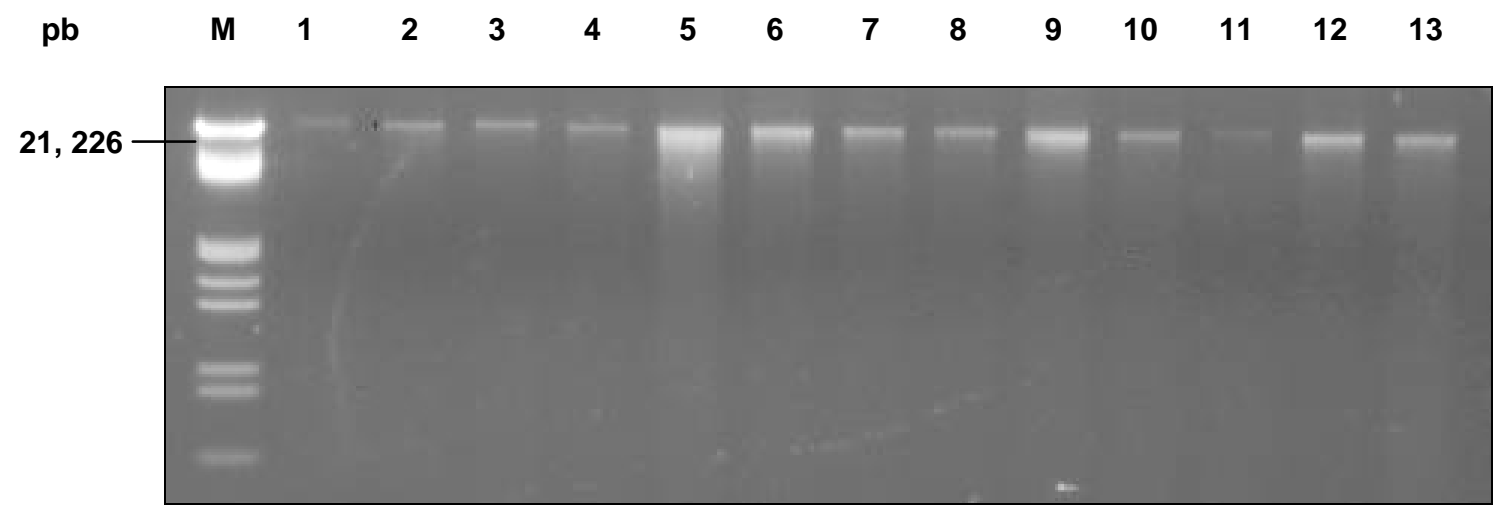

Figura 4 - DNA total dos isolados de cianobactérias. M - marcador molecular Lambda DNA/EcoR I + Hind III; 1 - Microcystis novacekii SPC503; 2 - Microcystis aeruginosa SPC777; 3 - Microcystis sp. SPC822; 4 - Sphaerocavum brasiliense SPC484; 5 Pseudanabaena galeata SPC772; 6 - Pseudanabaena mucicola SPC782; 7 Geitlerinema splendidum SPC923; 8 - Phormidium sp. SPC767; 9 - Rhabdoderma cocoide SPC766; 10 - Cylindrospermopsis raciborskii 339-T3; 11 - Raphidiopsis brookii 338-T2; 12 - Planktothrix sp. NPRG1; 13 - Microcystis protocystis SPC697.

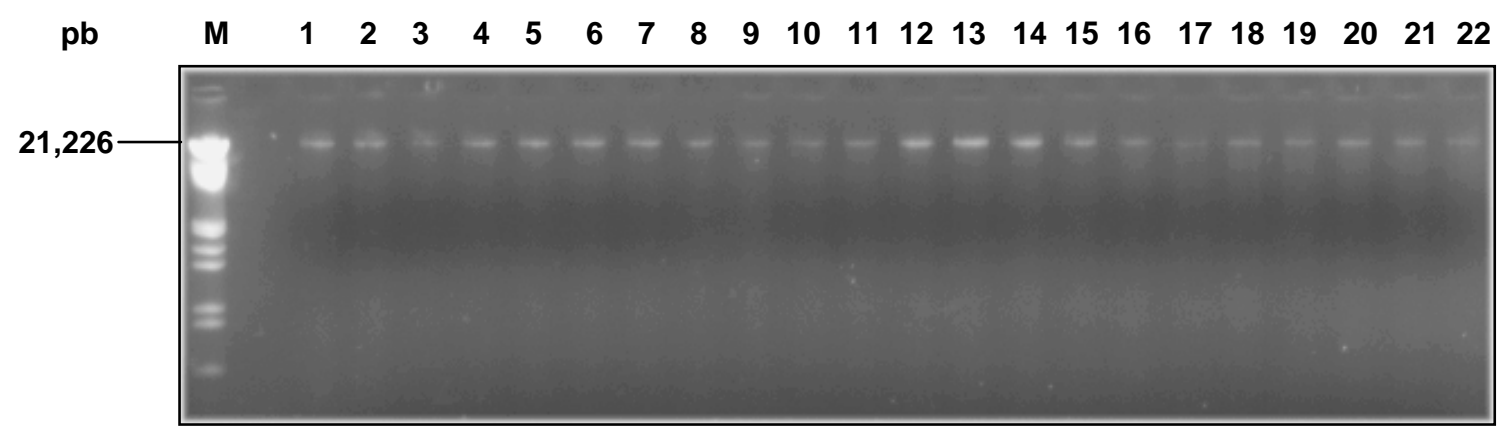

Figura 5 - DNA total extraído das amostras de água coletadas em diferentes locais das represas Billings e Guarapiranga. M - marcador molecular Lambda DNA/EcoR I + Hind III. Os números acima das canaletas correspondem às amostras identificadas na Tabela 1. 
seqüência não degenerada (CYA359F1) também foi utilizada, onde o "Y" foi substituído por "T", em virtude da constatação de maior identidade com as seqüências de cianobactérias depositadas no GenBank do National Center for Biotechnology Information (NCBI), conferida através de análise BLAST.

Amplicons resultantes de reações de PCR feitas com os iniciadores 27F1/1494Rc e CYA359F1/CYA781R podem ser vistos nas Figuras 6 e 7, respectivamente. Os produtos de PCR obtidos com ambos os conjuntos mostraram bandas com tamanhos esperados, resultando em fragmentos amplificados de aproximadamente 1500 pares de bases quando se utilizou os iniciadores 27F1/1494Rc e fragmentos de aproximadamente 450 pares de bases quando os iniciadores CYA359F1/CYA781R foram usados.

A variabilidade dos amplicons resultantes da reação de PCR com os iniciadores CYA359F1/CYA781R e CYA359F/CYA781R, foi avaliada através de eletroforese em gel de poliacrilamida com gradiente desnaturante (DGGE) (Figuras 8 e 9, respectivamente). Essa técnica foi utilizada primeiramente por Muyzer et al. (1993) e introduzida com sucesso em estudos de ecologia molecular microbiana. Ela consiste na separação dos fragmentos de DNA (principalmente do rDNA 16S) em um gel de poliacrilamida contendo um gradiente linear de desnaturantes (uréia e formamida). Moléculas de DNA com o mesmo tamanho, mas com seqüências diferentes de nucleotídeos, apresentam comportamento eletroforético distinto quando expostas ao gradiente de agentes desnaturantes (Muyzer et al., 1999). A seqüência de nucleotídeos (conteúdo de $\mathrm{G}+\mathrm{C}$ ) de um fragmento de DNA definirá a posição no gradiente em que o DNA de fita dupla irá parcialmente se desnaturar ("melting behavior").

Entretanto, o comportamento de migração do fragmento de DNA no gel de DGGE não é governado apenas pela composição de nucleotídeos (conteúdo de $\mathrm{G}+\mathrm{C}$ ), mas também pelas suas interações dentro da molécula (Breslauer et al., 1986). Desde que moléculas de DNA com seqüências diferentes apresentem taxas de migração distintas em géis desnaturantes, essa técnica é uma ferramenta bastante útil para a realização de estudos ecológicos com microrganismos (Rosembaum \& Riesner, 1987).

As Figuras 8 e 9 mostram os perfis no gel de DGGE dos amplicons de rDNA 16S das culturas puras de cianobactérias (canaletas A, B, C e D), tomadas como controle 
$\begin{array}{lllllllllllllllllllllllll}\text { pb } & M & 1 & 2 & 3 & 4 & 5 & 6 & 7 & 8 & 9 & 10 & 11 & 12 & 13 & 14 & 15 & 16 & 17 & 18 & 19 & 20 & 21 & 22 & \mathrm{C}\end{array}$

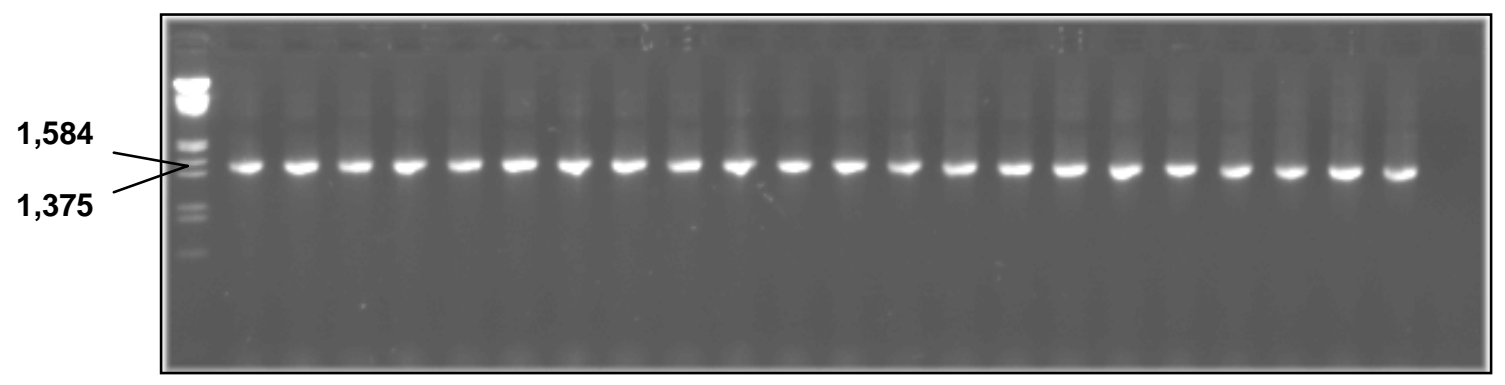

Figura 6 - Produtos de amplificação (oligonucleotídeos iniciadores 27F1/1494Rc) do gene de rRNA $16 \mathrm{~S}$ de cianobactérias presentes nas diferentes amostras de água. M marcador molecular lambda DNA/EcoR I + Hind III; C - controle negativo (sem DNA). Os números acima das canaletas correspondem às amostras identificadas na Tabela 1.

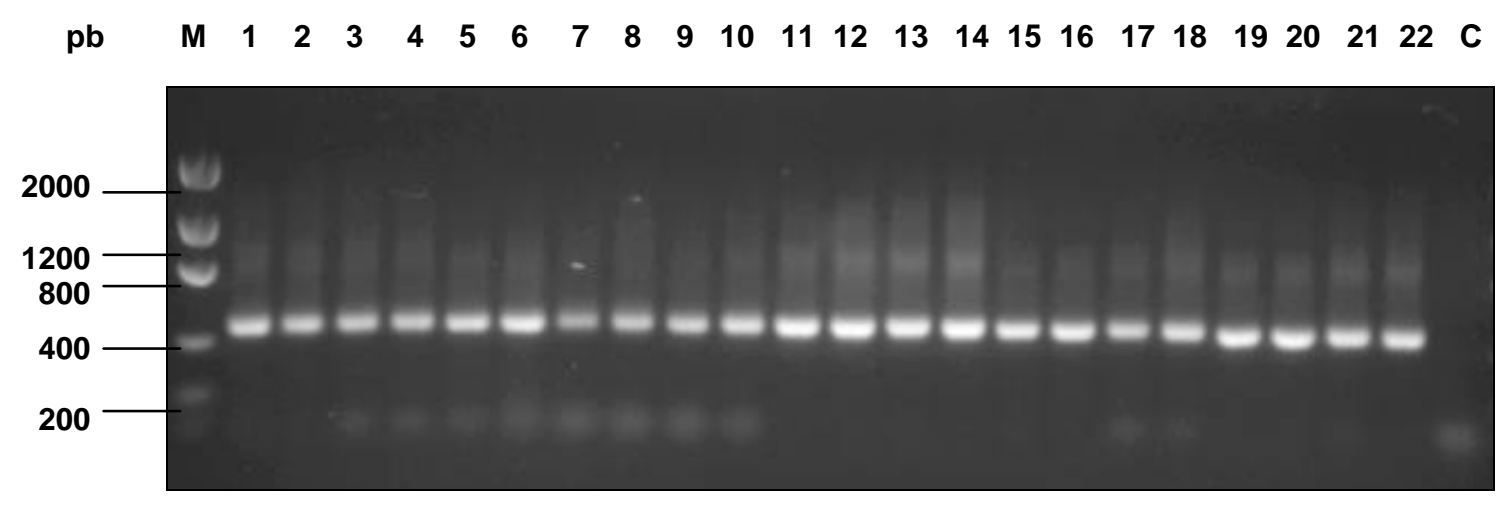

Figura 7 - Produtos de amplificação (oligonucleotídeos iniciadores CYA359F1/CYA781R) do rDNA 165 de cianobactérias. M - marcador molecular Low DNA Mass Ladder; C controle negativo (sem DNA). Os números acima das canaletas correspondem às amostras identificadas na Tabela 1. 


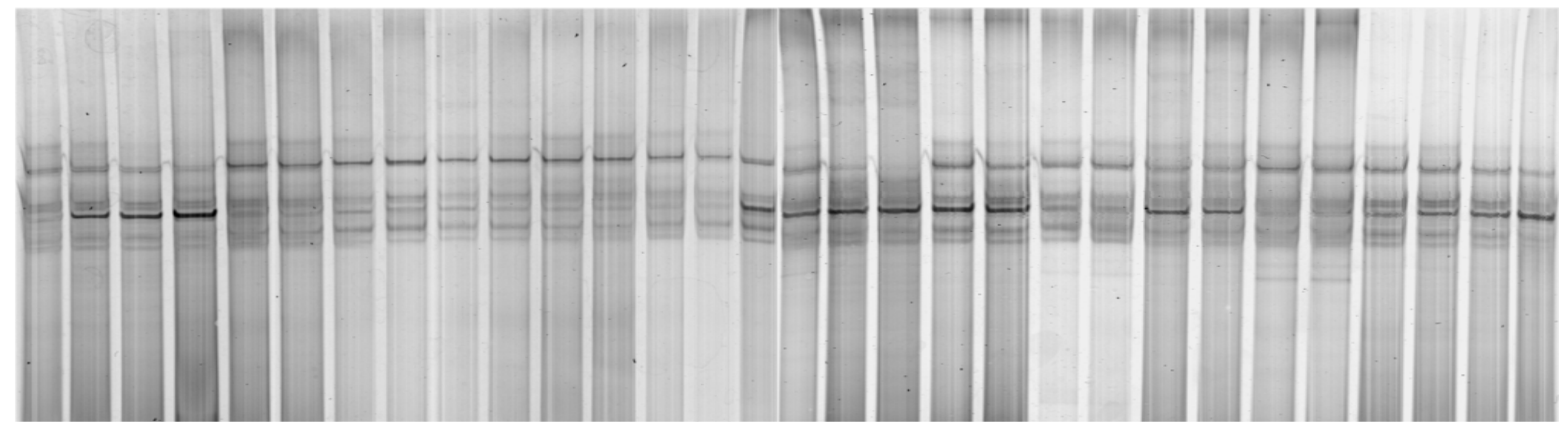

Figura 8 - Separação eletroforética por DGGE dos amplicons de rDNA 16S obtidos com os oligonucleotídeos iniciadores CYA359F1 (não degenerado) e CYA781R de culturas puras de cianobactérias ( $, B, C$ e D) e de amostras ambientais de água coletadas nas represas Billings e Guarapiranga. A - Microcystis aeruginosa NPJB1; B - Microcystis aeruginosa NPDC1 (não tóxica); C Microcystis panniformis SPC702; D - Cylindrospermopsis raciborskii 339-T3. Os números acima das canaletas correspondem às amostras identificadas na Tabela 1. 


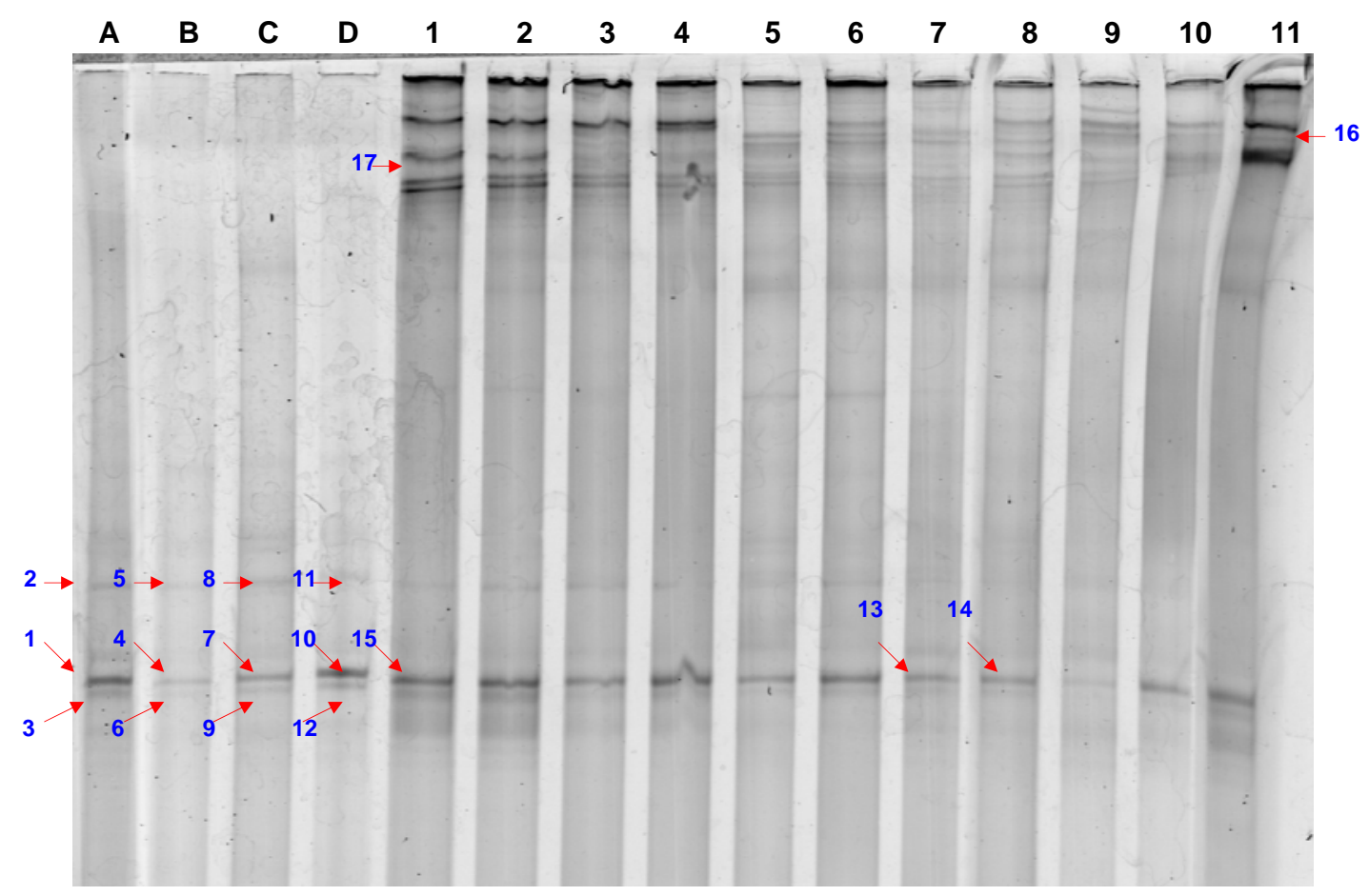

Figura 9 - Separação eletroforética por DGGE dos amplicons de rDNA 16S obtidos com os oligonucleotídeos iniciadores CYA359F (degenerado) e CYA781R de culturas puras de cianobactérias ( $A, B, C$ e $D$ ) e de amostras ambientais de água coletadas nas represas Billings e Guarapiranga. A - Microcystis aeruginosa NPJB1; B Microcystis aeruginosa NPDC1 (não tóxica); C - Microcystis panniformis SPC702; D - Cylindrospermopsis raciborskii 339-T3. Os números acima das canaletas correspondem às amostras identificadas na Tabela 1 . As setas numeradas indicam as bandas que foram excisadas do gel para o sequenciamento. 
positivo. Esperava-se que essas amostras apresentassem uma única banda para cada linhagem analisada (Microcystis aeruginosa NPJB1, Microcystis aeruginosa NPDC1, Microcystis panniformis SPC702 e Cylindrospermopsis raciborskii 339-T3). Entretanto, observou-se pelo menos três bandas mais evidentes para cada uma delas.

Em se tratando de culturas puras, a presença de mais de uma seqüência de rDNA $16 \mathrm{~S}$ no gel pode significar que os organismos possuem mais de uma cópia deste gene em seus genomas. Após a separação eletroforética dos amplicons por DGGE, normalmente se considera que cada banda produzida no gel desnaturante representa uma espécie microbiana. Todavia, sabe-se que muitas bactérias possuem mais de uma cópia do gene de rRNA $16 \mathrm{~S}$, as quais podem apresentar diferentes mobilidades no gel com gradiente desnaturante devido à pequenas variações em suas seqüências, resultando em múltiplas bandas para a mesma espécie microbiana (Nübel et al., 1996; Boon, 2000). Em algumas bactérias, tem sido observado de 1 a 15 cópias do rRNA 16S (http://www.cme.msu.edu/). Kerkhof \& Speck (1997) estudaram 20 bactérias marinhas heterotróficas, utilizando pequenas sondas ( $<600 \mathrm{bp}$ ) do gene de rRNA $16 \mathrm{~S}$ de Escherichia coli e análises de Southern Blot. Todas as estirpes bacterianas apresentaram entre 4 e 10 cópias desse gene nos seus genomas. De acordo com os mesmos autores, os dados obtidos ressaltam a importância do desenvolvimento de métodos moleculares quantitativos para melhor direcionar a dinâmica de populações marinhas, baseadas nas seqüências de rDNA 16S. Em cianobactérias, duas cópias do gene de rRNA $16 \mathrm{~S}$ foram observadas em quatro diferentes gêneros ( $N$. muscorum, Synechocystis PCC6803 e PCC7002, Synechococcus PCC6301 e P. marinus SS120) (Chen \& Widger, 1993; Kaneko et al., 1996a, b; Strehl et al., 1999). Recentemente, constatou-se a presença de até cinco cópias desse gene no genoma de cianobactérias heterocitadas (Iteman et al., 2002). Entretanto, para os gêneros utilizados neste estudo o número de cópias do rRNA 165 não é conhecido. Apesar disso, estudos realizados por Nübel et al. (1997) demonstraram a eficiência da combinação entre o PCR específico (iniciadores CYA359F/CYA781R) e a técnica de DGGE, obtendo um marcador molecular composto de cinco espécies de cianobactérias (Scytonema B-77-Scy.jav.; Synechococcus leopoliensis SAG 1402-1; Microcoleus chthonoplastes MP1-NDN-1; Geitlerinema PCC 9452 ("Microcoleus" 10mfx); Cyanothece PCC 7418), onde cada 
espécie apresentou uma única banda. O marcador obtido teve grande aplicação na comparação entre géis diferentes.

A técnica de DGGE tem se tornado uma ferramenta importante para a análise de comunidades microbianas em diferentes condições ambientais (Heuer \& Smalla, 1997), incluindo comunidades aquáticas (MacGregor, 1999; Nübel et al.,1997, 1999) e o monitoramento de mudanças nas suas estruturas em função de fatores como a poluição (Donner et al., 1996; Eichner et al., 1999; El Fantroussi et al., 1999; Ferris \& Ward, 1997; Ferris et al., 1997; Muyzer \& Smalla, 1998), por permitir a deteç̧ão de um grande número de microrganismos (Ward et al., 1990), dentre eles àqueles nãocultiváveis (Macnaughton et al., 1999). Porém, é importante ressaltar suas limitações quando utilizada em estudos de ecologia de microrganismos. A amplificação preferencial de algumas sub-populações dentro de uma comunidade microbiana complexa durante a PCR, de modo que as bandas observadas na DGGE representem apenas as espécies mais abundantes na amostra (Vetriani et al., 1999), constitui uma dessas limitações.

O padrão de bandeamento entre as diferentes amostras ambientais pareceu não apresentar grandes variações entre si quando utilizou-se o iniciador CYA359F1 (não degenerado) (Figura 8). O número de amplicons encontrado, representando as espécies de cianobactérias presentes nas represas Bllings e Guarapiranga, foi inferior ao número de espécies normalmente observado no monitoramento realizado pela CETESB. Essa possível subestimação já foi apontada por alguns autores como sendo intrínsecas às limitações da DGGE (Cury, 2000). Mesmo entre os dois gêneros distintos utilizados como controle positivo (Microcystis e Cylindrospermopsis), aparentemente não ocorreram variações. Diante disso, amplicons de baixa abundância poderiam não ser detectados pela metodologia adotada, principalmente quando a espécie representa menos de $1 \%$ da população total (Muyzer et al., 1999). Além do mais, os amplicons podem representar um grupo de espécies com conteúdo de $C+G$ similares, o que resultaria em comigração dos mesmos (Simpson et al., 1999).

Apesar da técnica de DGGE teoricamente ser capaz de distinguir fragmentos de DNA que diferem em apenas um par de bases, Jackson et al. (2000) mostraram em estudo feito com $E$. coli, que esta técnica não foi capaz de identificar diferenças entre 
mutantes que continham dois pares de bases distintos no fragmento de rDNA 16S. Isso significa que uma banda detectada no gel pode representar mais de uma espécie bacteriana, com diferentes seqüências, mas mesmo conteúdo de $\mathrm{G}+\mathrm{C}$. Quanto ao conteúdo de GC em cianobactérias, Brock \& Madigan (1988) reportam que a variação na composição de bases é 35-71\% de GC em espécies unicelulares e 39-47\% de GC em espécies herocitadas. Esses dados sugerem uma menor relação entre as espécies unicelulares em virtude da maior variação na composição de suas bases.

Os resultados obtidos utilizando o iniciador CYA359F (degenerado), indicam uma diminuição no número de bandas observadas para cada perfil de amostras no gel de DGGE (Figura 9), em comparação com os resultados encontrados quando se utilizou o iniciador CYA359F1 (não degenerado) (Figura 8). Por outro lado, a utilização do iniciador degenerado parece ter permitido o acesso a outras seqüências de rDNA 16S de cianobactérias existentes nas amostras ambientais. Esse fato pode ser constatado na parte superior do gel, na mesma figura.

Vários gradientes desnaturantes para a confecção dos géis também foram testados, sendo que o gradiente variando de 15 a $35 \%$ foi o que se mostrou mais satisfatório para a separação dos amplicons resultantes da amplificação feita com o iniciador CYA359F1 (não degenerado). Essas mesmas condições não se mostraram adequadas para a separação eletroforética dos amplicons obtidos por meio do CYA359F (degenerado), necessitando ainda serem otimizadas.

Torna-se claro que, apesar de todos os esforços realizados para confeccionar um gel de DGGE que realmente represente a diversidade de cianobactérias nas represas Billings e Guarapiranga, esse objetivo ainda não foi alcançado. Possivelmente a otimização das reações de PCR, permitindo a amplificação de seqüências do gene de rRNA $16 S$ a partir de DNA de amostras ambientais usando diretamente os iniciadores CYA359F/CYA781R, possa auxiliar na obtenção de melhores padrões de bandas. Outra possibilidade é desenhar iniciadores específicos capazes de realmente acessar a diversidade de cianobactérias do ecossistema terrestre. Uma alternativa seria utilizar as seqüências de região dos genes que codificam para o pigmento ficocianina, uma vez que esse pigmento, dentro do domínio Bacteria, está presente exclusivamente em cianobactérias (Bryant, 1982; Ernest, 1991; Glazer, 1989). 
Recentemente, Janse et al (2003) demonstraram a aplicabilidade da técnica de DGGE para cianobactérias em amostras ambientais de água, mas observaram que as vantagens e desvantagens do uso desta técnica estão associadas à região da seqüência de nucleotídeos estudada e ao conjunto de oligonucleotídeos iniciadores desenvolvidos. Concluíram que a região do espaço intergênico entre o $16 \mathrm{~S}$ e $23 \mathrm{~S}$ rRNA pode ser utilizada para a avaliação da diversidade de cianobactérias de forma bastante eficiente. A DGGE também tem sido usada para seqüências do rRNA-ITS em Synecchococcus (Becker et al., 2002) e Aphanizomenon (Laamanen et al., 2002).

Dezessete bandas excisadas do gel que mostra os amplicons obtidos com os iniciadores CYA359F/CYA781R foram purificadas e seqüenciadas, conforme indicado na Figura 9. Das bandas excisadas e seqüenciadas, a DGGE 10 e DGGE 13 não produziram seqüências de boa qualidade, portanto não foram consideradas nas análises. As seqüências obtidas para as demais bandas apresentaram a maior identidade na análise BLAST com as seguintes seqüências de cianobactérias: DGGE 1 - Microcystis viridis NIER-10020 (AY065976) (96\%); DGGE 2 - Microcystis viridis KCTC AG10198 (AY121357) (88\%); DGGE 3 - Microcystis aeruginosa NIVA-CYA 118/2 (Y12607) (97\%); DGGE 4 - Microcystis aeruginosa NIVA-CYA 57 (Z82785) (88\%); DGGE 5 - Microcystis aeruginosa KCTC AG10159 (AY121356) (90\%); DGGE 6 - Microcystis aeruginosa NIVACYA 57 (82785) (96\%); DGGE 7 - Microcystis aeruginosa NIVA-CYA 118/2 (Y12607) (98\%); DGGE 8 -Microcystis aeruginosa NIVA-CYA 118/2 (Y12607) (99\%); DGGE 9 Microcystis aeruginosa NIVA-CYA $118 / 2$ (Y12607) (89\%); $\quad$ DGGE 11 Cylindrospermopsis raciborskii Florida I (AF516746) (95\%); DGGE 12 Cylindrospermopsis raciborskii Florida I (AF516746) (96\%); DGGE 14 - Geitlerinema sp. PCC 7105 (AF132780) (89\%); DGGE 15 - Microcystis aeruginosa NIVA-CYA 57 (Z82785) (97\%); DGGE 16 - Microcystis aeruginosa NIVA-CYA 57 (Z82785) (94\%); DGGE 17 Synechococcus sp. MH301 ( AY224199) (89\%).

As comparações de seqüências visando encontrar os valores de identidade citados acima foram realizadas na tentativa de se identificar através das seqüências do gene de rRNA $16 \mathrm{~S}$ resultantes no gel de DGGE as espécies de cianobactérias. Pode-se observar que todas as seqüências obtidas e comparadas com as depositadas no banco de dados, apresentaram identidade com o grupo de cianobactérias. Entretanto, todos 
os valores de identidade obtidos foram inferiores a $97,5 \%$ indicando que, muito provavelmente, são espécies diferentes e em alguns casos (identidade inferior a 95\%) são gêneros diferentes. O sequenciamento do gene completo de rRNA 165 (aproximadamente 1500 pares de bases) teria de ser realizado para realmente confirmar essas identidades.

Dentro do domínio Bacteria, dois organismos são considerados da mesma espécie se eles apresentarem reassociação de DNA-DNA de aproximadamente $70 \%$ ou maior (Wayne et al., 1987). Foi observado que linhagens com seqüências do gene de rRNA 165 que apresentam valores de identidades inferiores a 97,5\% são improváveis de possuírem reassociação de DNA-DNA maior que 60-70\% e, portanto, improváveis de pertencerem à mesma espécie (Stackebrandt \& Goebel, 1994). Dois organismos têm sido considerados do mesmo gênero quando apresentam identidade de seqüências do rRNA 16S superior a 95\% (Ludwig et al., 1998).

As bandas DGGE 1, 2 e 3 seqüenciadas foram produzidas pela cianobactéria Microcystis aeruginosa NPJB1 (Azevedo et al., 1994), usada como um dos controles positivo. Da mesma forma, as bandas DGGE 4, 5 e 6 foram obtidas de Microcystis aeruginosa NPDC1; as DGGE 7, 8 e 9 de Microcystis panniformis SPC702 (Komárek et al., 2002) e as DGGE 11 e 12 de Cilindrospermopsis raciborskii 339-T3 (Lagos et al., 1999), culturas também usadas como controles. Essas três bandas encontradas em cada uma das cianobactérias foram escolhidas para sequenciamento, visando principalmente verificar a identidade entre elas, uma vez que, apesar de apresentarem perfis diferentes no gel de DGGE, elas foram geradas pelo mesmo organismo. Os valores de identidade obtidos entre as três bandas encontradas em $M$. aeruginosa NPJB1, M. aeruginosa NPDC1 e M. panniformis SPC702 variaram de 81 a 92\%, 78 a $82 \%$ e $88-98 \%$, respectivamente. Para a C. raciborskii 339-T3 foi possível analisar somente duas seqüências (DGGE 11 e 12), apresentando identidade entre elas de 86\%. Esses resultados comprovaram que as várias seqüências do gene de rRNA 165 encontradas na mesma cianobactéria e separadas por DGGE, são realmente diferentes uma das outras e portanto, conforme discutido anteriormente, podem representar cópias deste gene dentro do genoma do organismo, ou ainda ser artefatos originados nas amplificações por PCR. 
As quatro bandas provenientes das amostras ambientais de água (DGGE 14, 15, $16,17)$ obtidas com o iniciador degenerado, também mostraram a maior identidade, verificada através de análise BLAST, com seqüências de cianobactérias, indicando a especificidade dos iniciadores CYA359F/CYA781R desenhados por Nübel et al (1997), embora haja necessidade de mais bandas serem seqüências para realmente confirmar este fato.

Inferências filogenéticas entre as seqüências do gene de rRNA $16 \mathrm{~S}$ obtidas foram realizadas através da construção de uma árvore filogenética (Figura 10). Outras seqüências desse gene retiradas do banco de dados do GenBank também foram utilizadas (M. flos-aquae UWOCCC3 - AF139329; Microcystis sp. UWOCCCBS AF139307; Microcystis sp. UWOCCBauldE - AF139312; M. novacekii TAC65 - AB012337; M. aeruginosa NIVA-CYA57 - Z82785; M. viridis NIER-10020 - AY065976; M. viridis KCTC AG10198 - AY121357; M. aeruginosa NIVA-CYA118/2 -Y12607; M. aeruginosa KCTCAG10159 - AY121356; M. wesenbergii -D89034; C. raciborskii Florida I AF516746; Synecchococcus sp. MH301 - AY224199; Prochlorococcus sp. MIT9313 AF053399; Geitlerinema sp. PCC7105 - AF132780).

A Figura 10, mostra as distâncias genéticas calculadas a partir do alinhamento de seqüências de aproximadamente 450 pb do rDNA $16 S$ de cianobactérias. A árvore filogenética construída foi enraizada usando uma seqüência de $E$. coli (J01859) como grupo externo. Numa análise de reamostragem para 1000 replicações, as seqüências correspondentes às bandas DGGE 11 e 12 foram agrupadas no mesmo clado, conforme o esperado, uma vez que estas seqüências são provenientes do mesmo genótipo de Cylindrospermopsis raciborskii 339-T3, um dos controles usados no gel de DGGE. A cianobactéria Cylindrospermopsis raciborskii Florida I apresentou-se intimamente relacionada à Cylindrospermopsis raciborskii 339-T3, apesar da identidade entre elas ter sido inferior à $97 \%$.

Um fato interessante observado na árvore filogenética foi o agrupamento claramente distinto, em um clado à parte, das seqüências obtidas das bandas provenientes das linhagens brasileiras de Microcystis. 
ESCALA 0.1

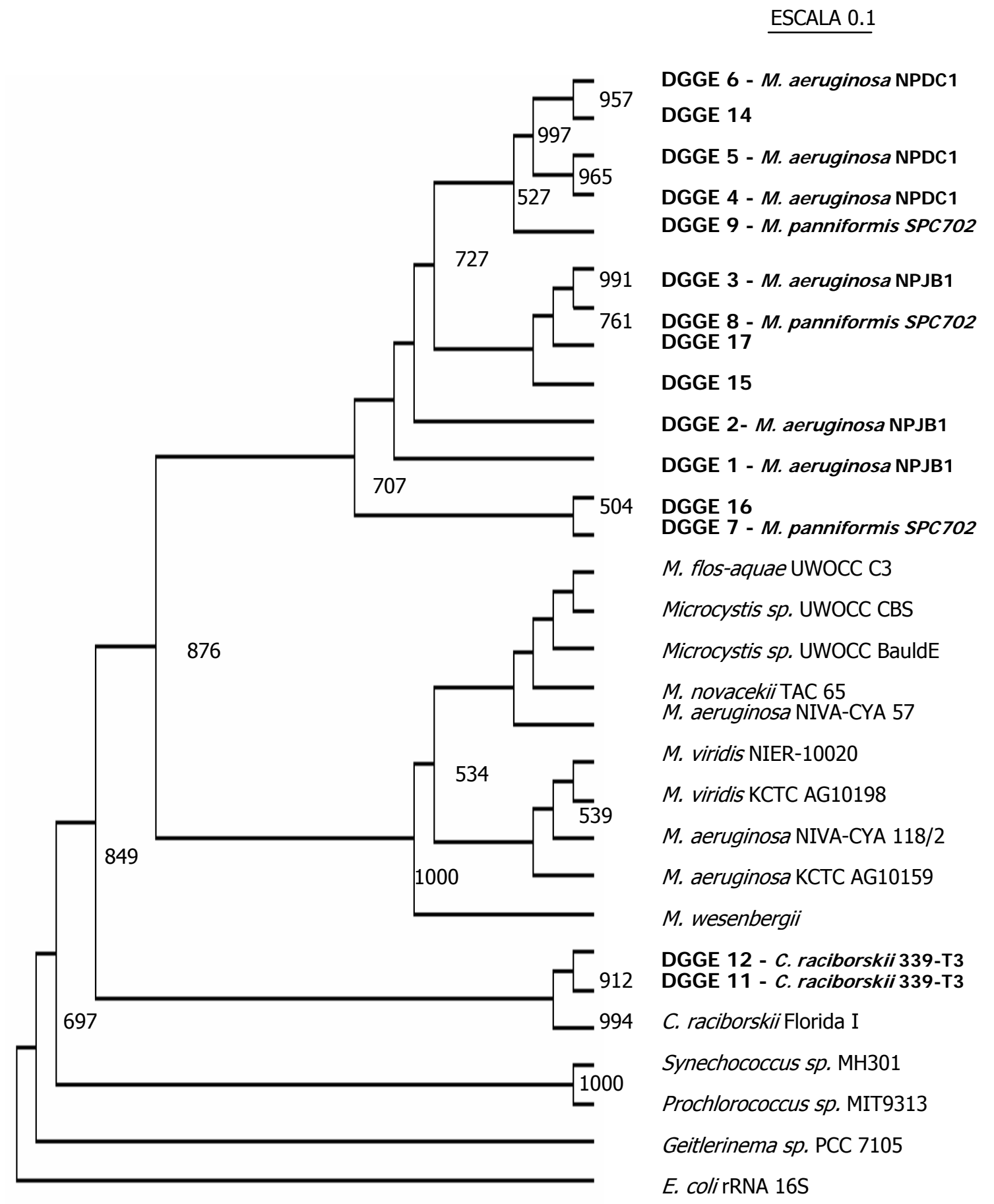

Figura 10 - Relações filogenéticas entre o rDNA 16S de cianobactérias. Organismos cujos fragmentos do gene rRNA $16 \mathrm{~S}$ foram seqüenciados neste estudo estão em negrito. A árvore foi enraizada usando o gene rRNA $16 \mathrm{~S}$ de $E$. coli como um grupo externo. Valores superiores à $50 \%$ na reamostragem de 1000 árvores são indicados nos clados (Felsenstein, 1985). 


\subsection{Análise da biodiversidade de cianobactérias por meio da construção de mini-bibliotecas}

Diante das limitações apresentadas pela técnica de DGGE, devido aos iniciadores utilizados, para estimar a diversidade das cianobactérias presentes nas represas Billings e Guarapiranga, optou-se por fazer mini-biblioteca de seqüências de gene. A amostra de água selecionada para realizar este estudo foi a que apresentou o maior teor de microcistinas $(23,49 \mu \mathrm{g} / \mathrm{L})$, ou seja, a amostra coletada no braço do Taquacetuba da represa Billings, na linha de transmissão (BITQ00900 - amostra 98481, Tabela 1). Os resultados dos teores de microcistinas em todas as amostras de água utilizadas foram fornecidos pela CETESB e apresentaram as seguintes concentrações $(\mu \mathrm{g} / \mathrm{L}): 1,44$ - amostra 95714; 0,68 - amostra 95716; 3,48 - amostra 97263; 23,49 amostra 98481; 5,92 - amostra 98479; 0,39 - amostra 23765; 0,16 - amostra 26874; 0,35 - amostra 29160; 0,17 - amostra 29165; <0,15 - amostra 29162;<0,15 amostra 29167 (dados não publicados). Como pode ser observado, em todas as amostras de água das represas Billings e Guarapiranga utilizadas foi detectada a presença de microcistinas.

\subsubsection{Mini-biblioteca de amplicons do gene de rRNA 16S}

O amplicon de rRNA $16 \mathrm{~S}$ número 7 da Figura 6, produzido usando o DNA extraído da amostra ambiental número 98481 (Tabela 1), com aproximadamente 1500 pares de bases, foi o utilizado para a construção da mini-biblioteca deste gene. 0 resultado da reação de PCR, usando os iniciadores 16S 27F1/1494Rc e os DNAs plasmidiais contendo os insertos de interesse, de 100 clones selecionados, é apresentado na Figura 11. Todas as colônias brancas selecionadas produziram amplicons, com exceção do clone 36. Assim, o RFLP foi realizado com 99 amplicons, os quais foram digeridos com a enzima de restrição HaeIII. O padrão de bandas obtido para os 99 amplicons pode ser observado na Figura 12. Selecionou-se aleatoriamente dois clones (clones 9 e 19), os quais foram seqüenciados para determinar suas respectivas identidades. As seqüências geradas foram anotadas e comparadas pela análise BLAST do GenBank. A maior porcentagem de identidade verificada para as seqüências dos clones 9 e 19 foram 93\% com o clone NM3 (AJ575536) e 95\% com o 


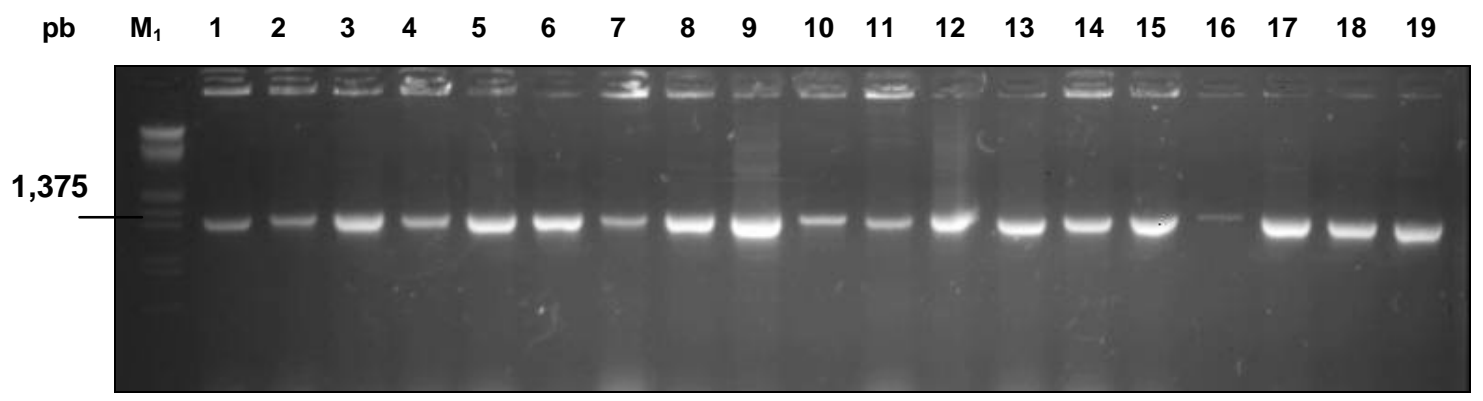

pb $\quad M_{1} 202122 \quad 2324252627282930313233 \quad 3435363738 \quad 39404142434445464748$
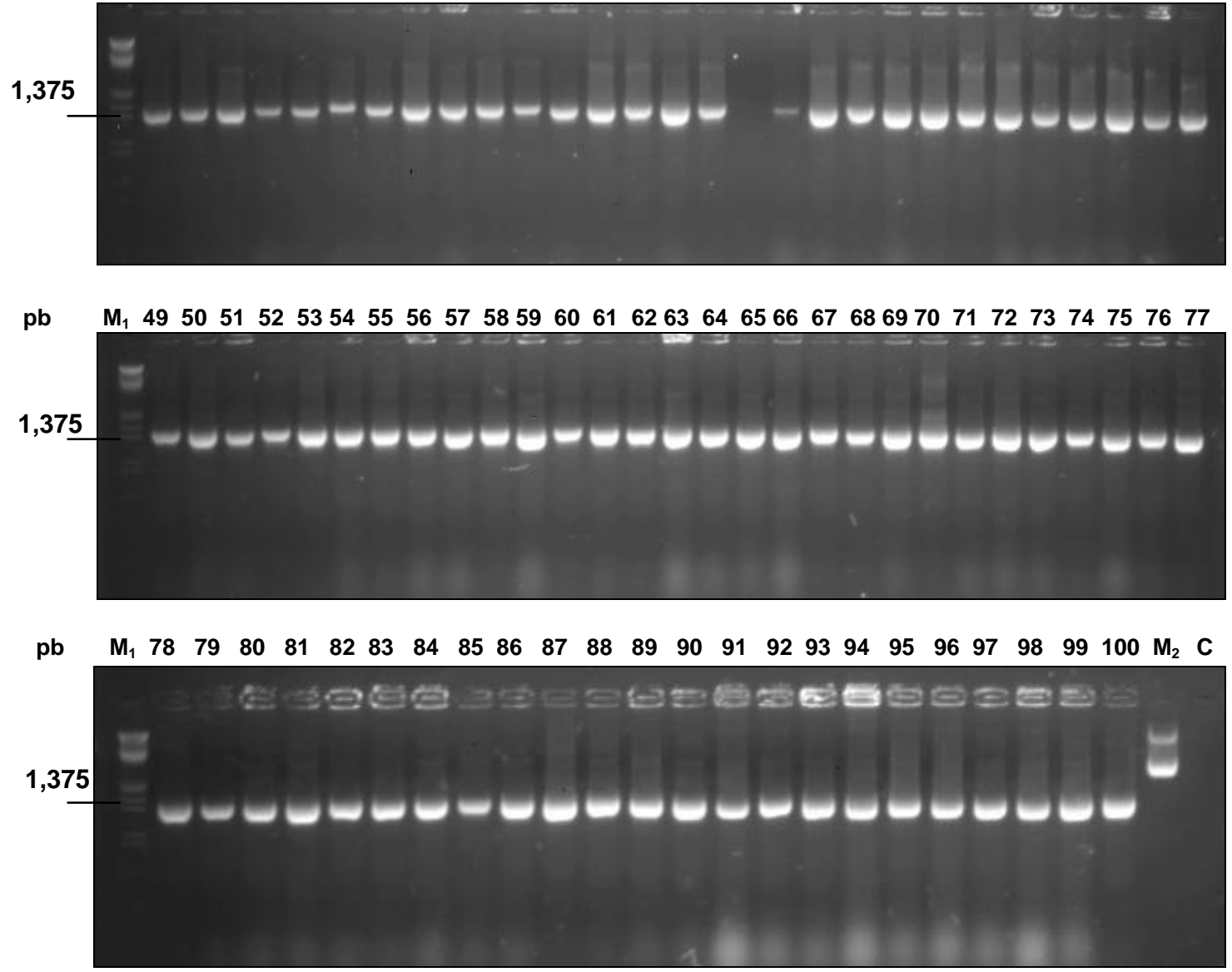

Figura 11 - Produtos de amplificação (oligonucleotídeos iniciadores 27F1/1494Rc) de 100 clones oriundos da amostra 98481 coletada na represa Billings. $M_{1}$ - marcador molecular lambda DNA/EcoR I + Hind III; $\mathrm{M}_{2}$ - padrão de massa molecular PGEM $^{\circledR} 3$ Zf (+); C - controle negativo (sem DNA). 


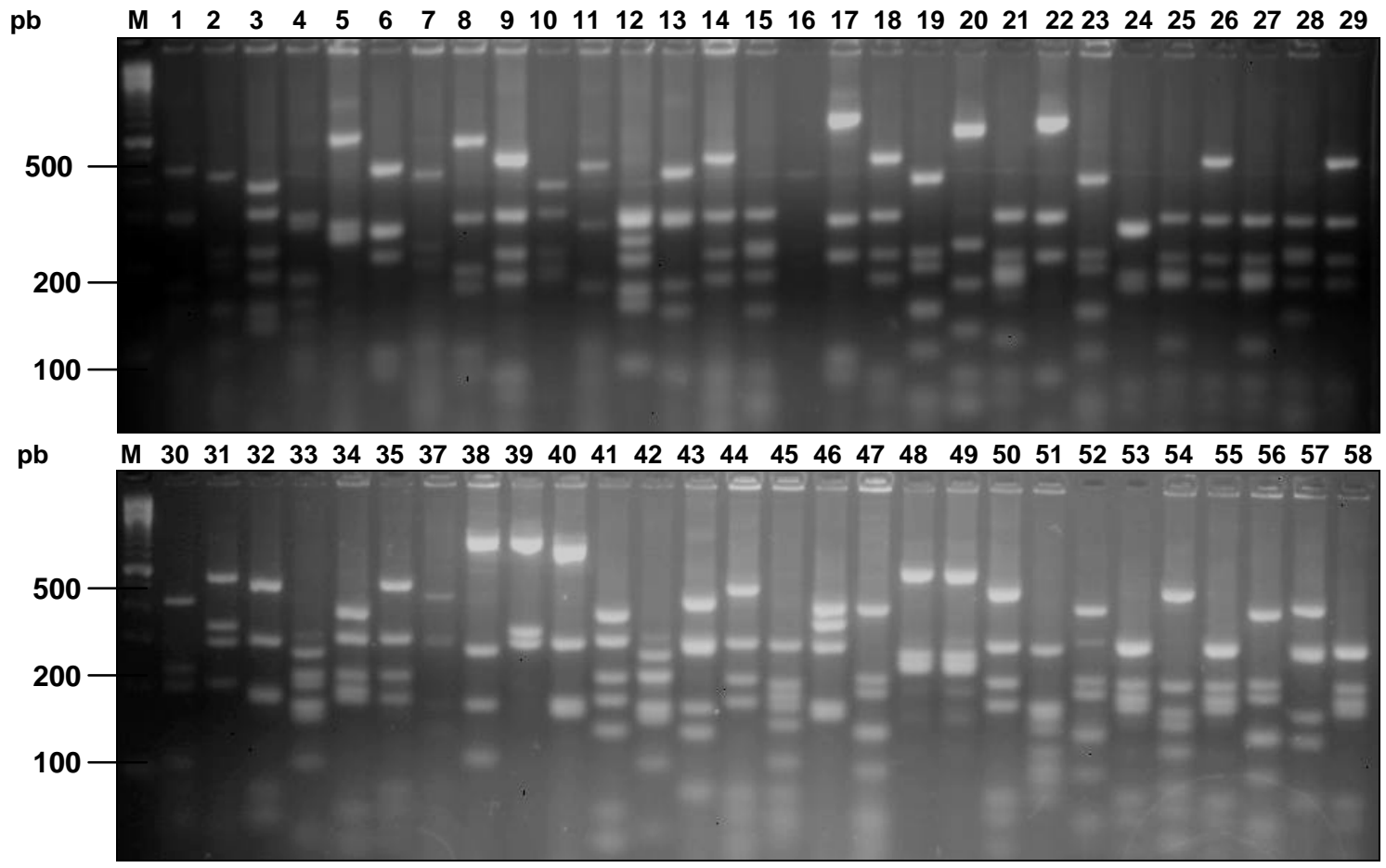

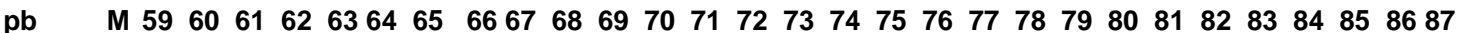

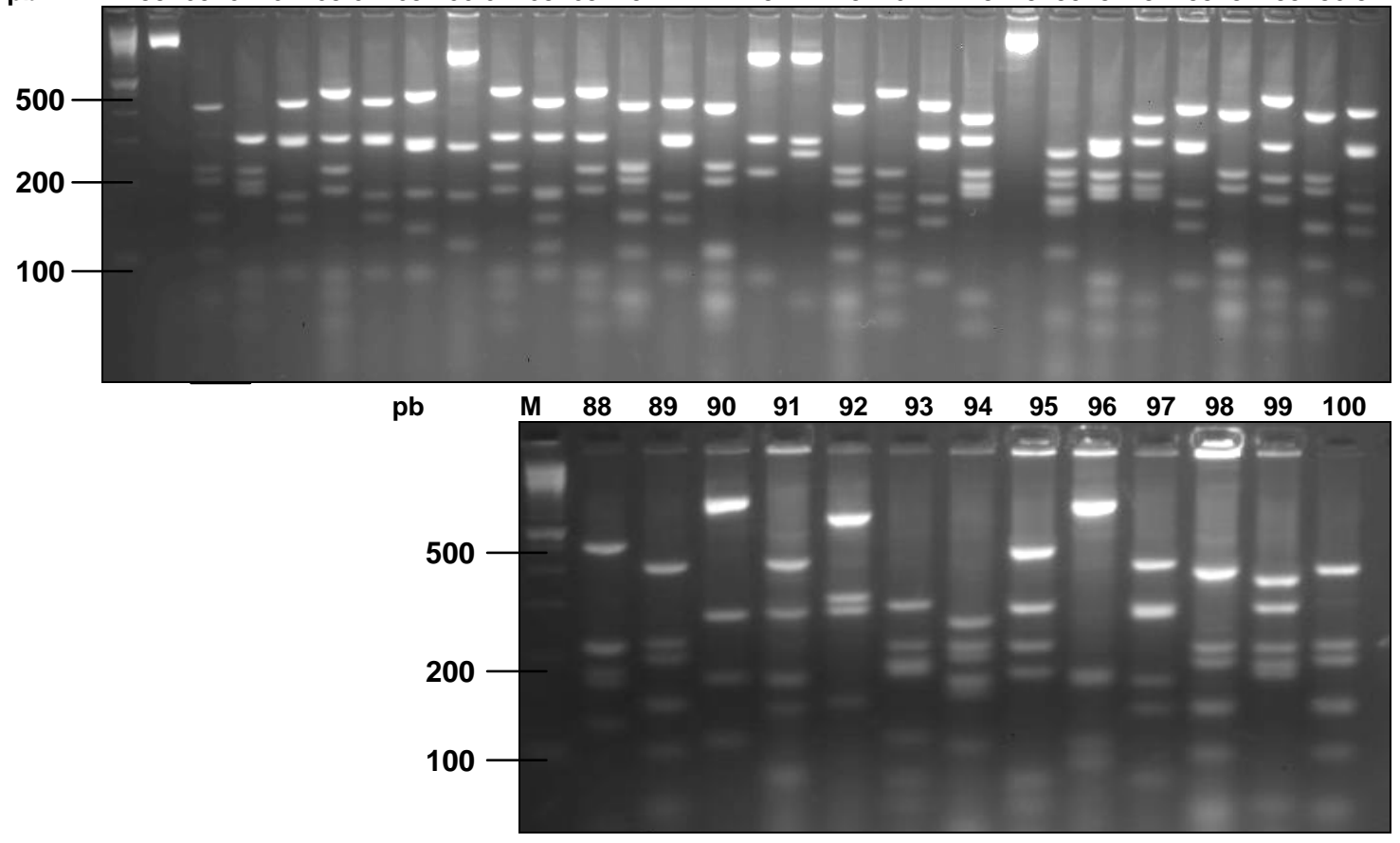

Figura 12 - Separação eletroforética dos fragmentos resultantes do RFLP realizado com a enzima de restrição Hae III, para 99 clones. M - marcador molecular 100 pb DNA Ladder. 
clone NO6 (AJ575558), respectivamente. Esses dois clones depositados no GenBank foram obtidos de DNAs extraídos de amostras de água doce, sem que os microrganismos fossem isolados e cultivados, utilizando iniciadores específicos de rRNA $16 \mathrm{~S}$ para o grupo Actinobacteria. Assim, as seqüências obtidas neste estudo, de acordo com a comparação feita, são de Actinobacteria. Para certificar-se da especificidade dos iniciadores 27F1/1494Rc, fez-se análise BLAST no GenBank com suas seqüências, ficando constatado que eles apresentavam identidade com seqüências de outros grupos de bactéria e não somente com as cianobactérias.

O conjunto de iniciadores 27F1/1494Rc vem sendo usado com sucesso para o sequenciamento do gene de rRNA $16 \mathrm{~S}$ de culturas puras de cianobactérias (Neilan et al., 1999; Tillett et al., 2001), inclusive no Laboratório de Biologia Celular e Molecular do CENA/USP. A amplificação não específica para cianobactérias desses iniciadores encontrada neste estudo em amostras ambientais, pode talvez ser explicada pelo fato de que o número de seqüências depositadas nos bancos de dados, selecionadas e alinhadas para desenhá-los, em 1997, era bem inferior se comparado ao número de seqüências hoje depositadas. Dessa forma, a especificidade encontrada há seis anos atrás para esses iniciadores pode ter deixado de existir, à medida que foram ficando conhecidas mais seqüências do gene de rRNA $16 \mathrm{~S}$ dos mais diversos organismos. Ficou constatado, portanto, que esses iniciadores, embora bastante úteis para amplificar seqüências de culturas puras de cianobactérias, não são adequados para serem usados em amostras ambientais. Poucas seqüências do gene de rRNA 16S de cianobactérias presentes no ecossistema brasileiro foram seqüenciadas e depositadas em bancos de dados públicos até o momento $e$, provavelmente, as seqüências consideradas na confecção desses iniciadores podem não terem sido representativas das cianobactérias presentes nas nossas condições.

\subsubsection{Mini-biblioteca de amplicons da região do PC-IGS}

Visando contornar o problema de especificidade dos iniciadores do gene de rRNA 16S, buscou-se então realizar a construção de uma outra mini-biblioteca, tomando-se como seqüência alvo a região do espaço intergênico da ficocianina (PCIGS). Dentro do domínio Bacteria o pigmento ficocianina é encontrado exclusivamente 
em cianobactérias (Bryant, 1982; Ernest, 1991; Glazer, 1989). O operon PC de cianobactérias possui uma região de espaço intergênico (PC-IGS) entre os dois genes cpcB e cpcA que é relativamente grande, se comparada com outras existentes nos genes do pigmento fotossintético de cianobactérias, e que apresenta suficiente grau de polimorfismo para separar estes organismos em nível de espécies e, em alguns casos, até em nível de linhagens (Bolch et al., 1996; Neilan et al., 1995).

A amplificação por PCR da seqüência da região do PC-IGS, usando o DNA extraído da amostra 98481 (Tabela 1) e os iniciadores PCBF/PCaR, resultou em amplicons com aproximadamente 600 pares de bases, conforme o esperado (Figura 13). Essa região do operon da ficocianina tem sido bastante usada atualmente para inferir relações filogenéticas entre linhagens de cianobactérias, uma vez que a taxa de substituição de seus nucleotídeos é potencialmente mais alta que as seqüências amplamente usadas do rRNA 16S (Bittencourt-Oliveira et al., 2001; Neilan et al., 1995; Bolch et al., 1996; Tillet et al., 2001). Baker et al (2001), usando os iniciadores PCBF/PCaR para identificar linhagens de cianobactérias em amostras do ambiente, estudaram a diferenciação entre os organismos deste grupo através de RFLP (polimorfismo nos fragmentos de restrição do DNA) e/ou sequenciamento dos produtos de PCR. Apesar dos níveis elevados de identidade das regiões do PC-IGS dentro do mesmo gênero, eles observaram dois clones de $M$. aeruginosa numa floração (T-96) do reservatório de Malpas, na Austrália, os quais apresentavam diferenças em suas seqüências, indicando possivelmente a presença de duas linhagens diferentes. Esse fato coincide com outro estudo onde os resultados de análises de RFLP do PC-IGS de isolados de florações de $M$. aeruginosa, mostraram diferenças entre dois genótipos (Bolch et al., 1996). Baker et al. (2001) concluíram que embora essa região seja relativamente conservada, ela com certeza é capaz de identificar cianobactérias em nível de gênero e possivelmente de espécie, tendo polimorfismo suficiente (pelo menos em algumas ocasiões) para diferenciar linhagens.

O produto de PCR mostrado na Figura 13 foi utilizado para a construção da mini-biblioteca da região do PC-IGS. Reações de PCR foram realizadas para 300 clones, usando os iniciadores PCBF/PCaR e os DNAs plasmidiais contendo os insertos de interesse. Alguns dos produtos de PCR obtidos são apresentados na Figura 14. Para a 


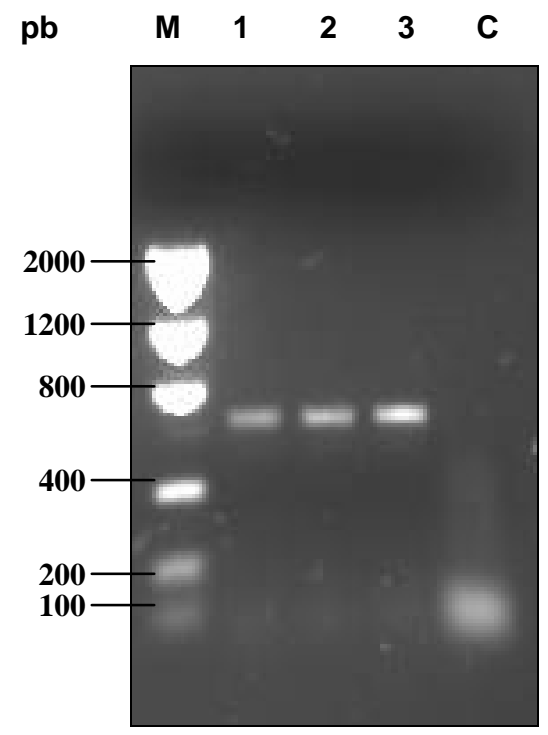

Figura 13 - Produtos de amplificação (oligonucleotídeos iniciadores PCBF/PCaR) do espaço intergênico da ficocianina. M - marcador molecular Low DNA Mass Ladder; 1, 2, e 3 - amplicons, cujas reações de PCR foram feitas separadamente para a amostra ambiental número 98481 (Tabela 1); C - controle negativo (sem DNA). 

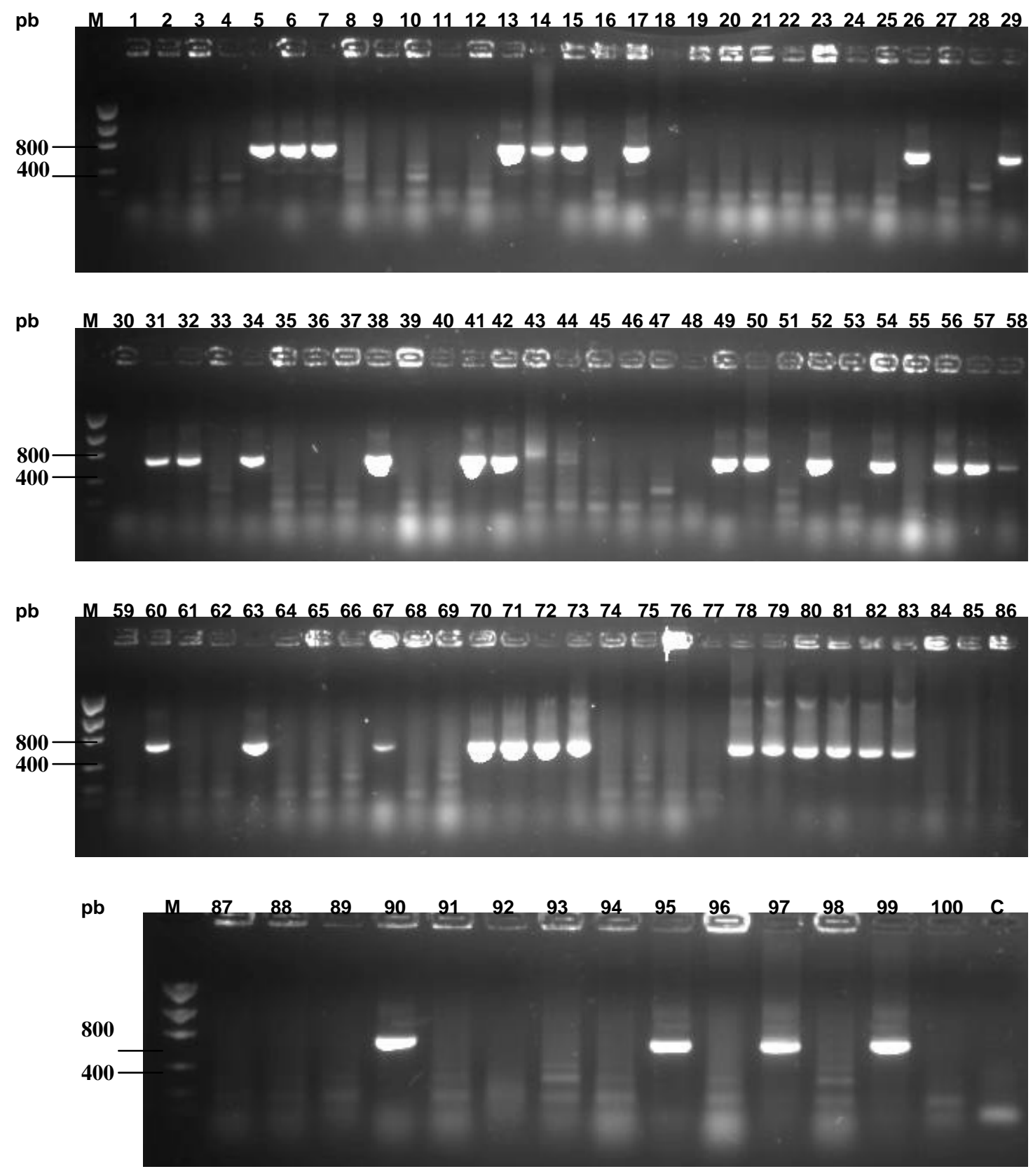

Figura 14 - Produtos de amplificação (oligonucleotídeos iniciadores PCBF/PCaR) de 100 clones oriundos da amostra 98481 coletada na represa Billings. M - marcador molecular Low DNA Mass Ladder; C - controle negativo (sem DNA). 
realização do RFLP foram selecionados 84 amplicons, os quais foram digeridos com a enzima de restrição $A / u$ I. $O$ padrão de bandas obtido para os 84 amplicons pode ser observado na Figura 15. Esse resultado mostra que a diversidade de cianobactérias observada na amostra de água coletada no braço do Taquacetuba da represa Billings, não foi alta, uma vez que dos 84 clones submetidos a análise de RFLP, somente sete padrões distintos de bandas foram visualizados. Esse fato era esperado, de certa forma, uma vez que é sabido que em águas eutrofizadas, como no caso da represa Billings, existe a tendência de predominar somente alguns poucos gêneros de cianobactérias e, em alguns casos, apenas uma espécie.

Os clones 7, 13, 17, 54, 73, 88 e 99 (Figura 15), representando os sete padrões de bandas encontrados, foram selecionados para o sequenciamento e tiveram suas seqüências posteriormente comparadas pela análise BLAST, a qual mostrou a maior identidade com os seguintes organismos, respectivamente: Microcystis aeruginosa UWOCC E7 (AF195175) (100\%); M. aeruginosa (AY117041) (99\%); M. aeruginosa UWOCC E7 (AF195175) (100\%); M. aeruginosa FCLA-310 AF385378) (98\%); Microcystis aeruginosa (AY117041 (99\%); Anabaena PCC7120 (AF178757) (89\%); Anabaena PCC7120 (AF178757) (89\%). Os dados obtidos mostram a presença de diferentes linhagens de $M$. aeruginosa no local amostrado e também permitem observar que a região do PC-IGS apresentou variabilidade suficiente para identificar as diferenças nas seqüências de nucleotídeos de algumas destas linhagens. Os clones $88 \mathrm{e}$ 99 podem representar espécies novas de Anabaena e/ou outro gênero, uma vez que mostraram baixa porcentagem (89\%) de identidade com a cianobactéria Anabaena PCC7129. Interessante notar que esses dois gêneros de cianobactérias conhecidos por produzirem microcistinas foram detectados, pela técnica molecular utilizada, na amostra de água que continha alta concentração dessa toxina $(23,49 \mu \mathrm{g} / \mathrm{L})$.

Neste estudo, somente foi possível a identificação de uma pequena fração das cianobactérias freqüentemente observadas na represa Billings. Entretanto, ele permitiu constatar que a seqüência da região do espaço intergênico da ficocianina é bastante específica para identificar cianobactérias em amostras ambientais. Seria extremamente útil realizar a construção de uma biblioteca de amplicons da região PC-IGS para cada uma das amostras ambientais coletadas. 

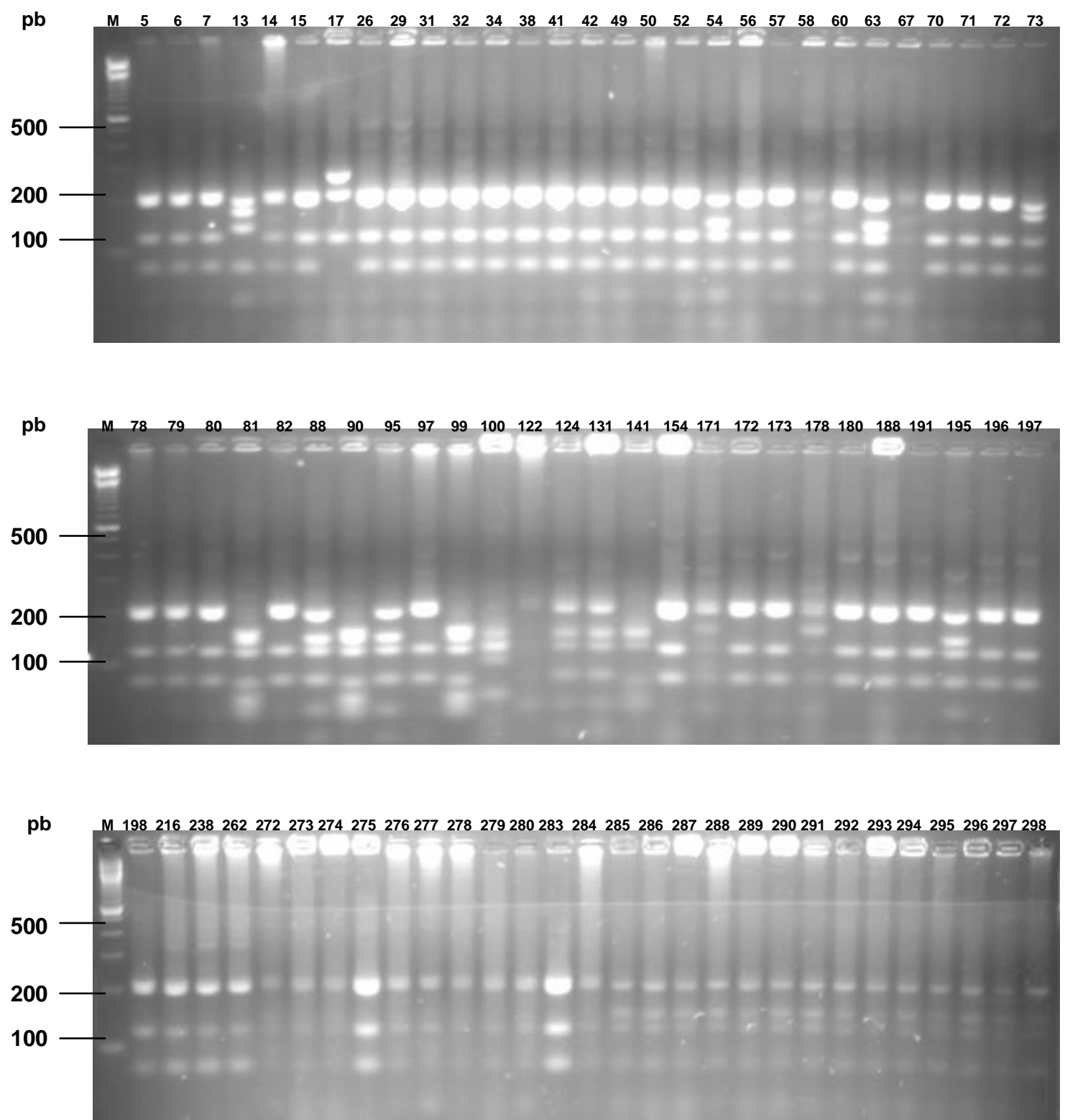

Figura 15 - Separação eletroforética dos fragmentos resultantes do RFLP realizado com a enzima de restrição Alu I, para 84 clones. M - marcador molecular 100 pb DNA Ladder. 
As inferências filogenéticas entre as seqüências de DNA obtidas foram realizadas através da construção de uma árvore filogenética. Outras seqüências retiradas do banco de dados do GenBank também foram utilizadas ( $M$. aeruginosa PCC7941 AF385388; M. aeruginosa NIES 98 - AF385384; M. aeruginosa EAWAG 171 - AJ003179; M. aeruginosa NIES98 - AF385385; M. aeruginosa EAWAG94a - AJ0031171; M. aeruginosa UWOCC023 - AF195169; M. aeruginosa UWOCC017 - AF195170; M. aeruginosa UWOCCCBS - AF195174; M. aeruginosa UWOCCMR-C - AF195173; $M$. aeruginosa UWOCCMR-D - AF195172; M. aeruginosa UWOCC92a - AJ003170; M. aeruginosa EAWAG167 - AJ003176; M. aeruginosa FCLA-003 - AF385380; $M$. wesenberuii NIES111 - AF385390; M. wesenberuii NIES112 - AF385391; Anabaena solitaria NIES80 - AY181213; A. circinalis - AY117039; Anabaena PCC7120 - AF178757; Oscillatoria sp. PCC7517 - AJ401185).

A Figura 16 mostra as distâncias genéticas calculadas a partir do alinhamento de seqüências de aproximadamente 600 pb do PC-IGS. A árvore filogenética foi enraizada usando como grupo externo uma seqüência de nucleotídeos retirada do GenBank, referente ao gene de ficocianina existente no plastídio da alga vermelha Aglaothamnion neglectum (Z11906) (Apt \& Grossman, 1993). Numa análise de reamostragem para 1000 replicações, os clones 88 e 99 foram agrupados no mesmo clado, distanciando-se do clado que agrupou as três espécies distintas de Anabaena selecionadas no GenBank. Conforme citado anteriormente, a análise BLAST feita para ambos os clones, apresentam a maior porcentagem de identidade com Anabaena PCC7120, entretanto, esta identidade foi baixa (89\%), indicando que, provavelmente, trata-se de duas espécies diferentes ou até mesmo de outro gênero de cianobactérias.

\subsection{Deteç̧ão do domínio NMT do gene mcyA}

Os resultados da amplificação por PCR da seqüência completa do domínio único da $N$-metiltransferase (NMT) do gene $m c y A$, usando DNA extraído de treze cianobactérias (Figura 4) e os iniciadores MSF/MSR são apresentados na Figura 17A. Como pode ser verificado o tamanho esperado de 1300 pares de bases para esse conjunto de iniciadores, foi obtido. Esse conjunto amplificou seqüências do mcyA nas espécies controles, Microcystis aeruginosa NPJB1 ( $\left.\mathrm{CP}_{1}\right)$ e Microcystis panniformis 
ESCALA 0.1

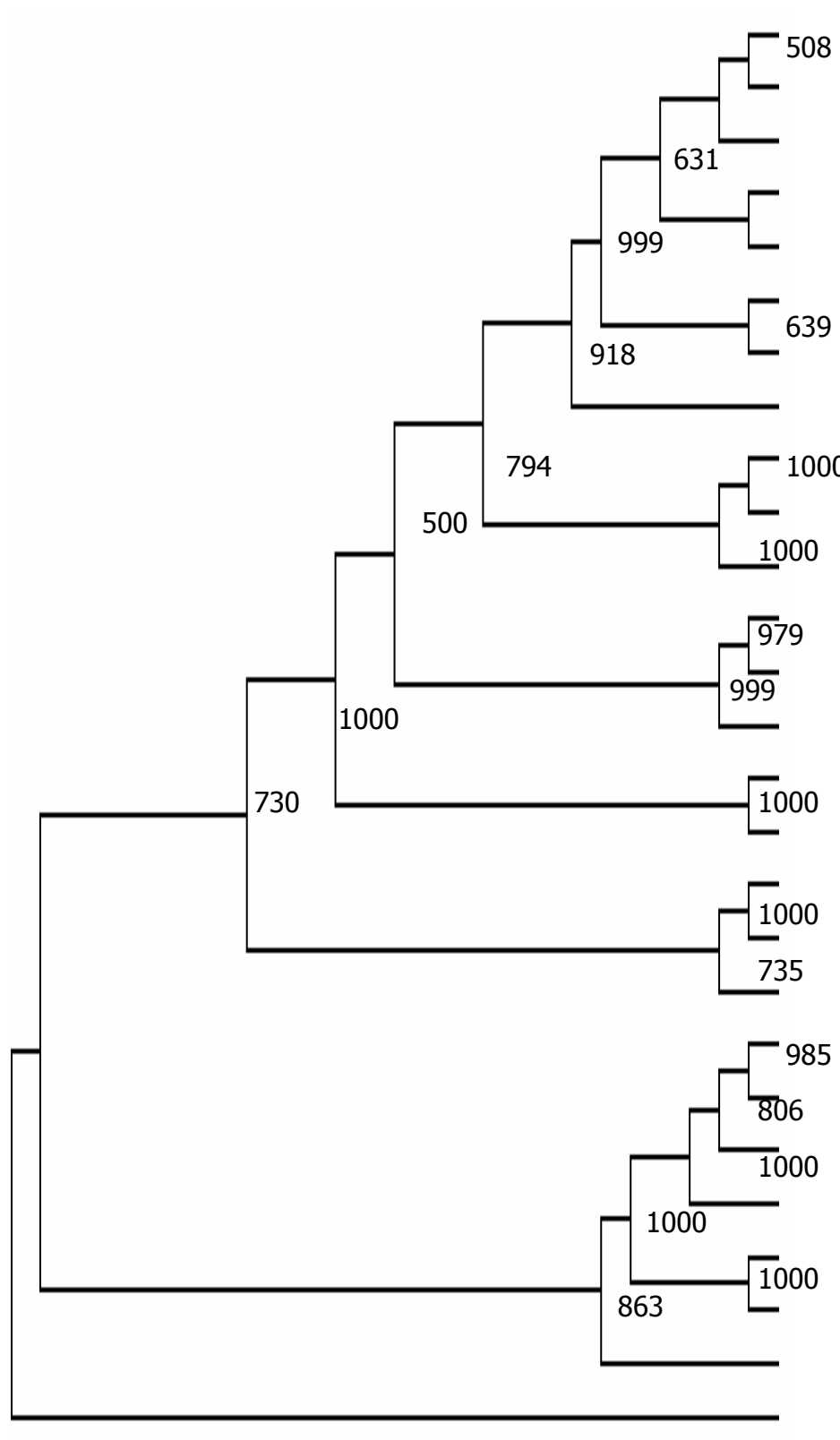

M. aeruginosa PCC 7941

M. aeruginosa NIES 98

M. aeruginosa EAWAG 171

M. aeruginosa NIES 99

M. aeruginosa EAWAG 94a

M. aeruginosa UWOCC 023

M. aeruginosa UWOCC 017

\section{Clone 17}

M. aeruginosa UWOCC CBS

M. aeruginosa UWOCC MR-C $M$. aeruginosa UWOCC MR-D

M. aeruginosa UWOCC 92a

M. aeruginosa EAWAG 167

M. aeruginosa FCLA-003

M. wesenbergii NIES 111

M. wesenbergii NIES 112

Anabaena solitaria NIES 80

Anabaena circinalis

Anabaena PCC7120

\section{Clone 13}

Clone 73

Clone 54

Clone 7

Clone 99

Clone 88

Oscillatoria sp. PCC7515

A. neglectum

Figura 16 - Relações filogenéticas entre a região do PC-IGS de cianobactérias. Organismos cujas regiões do PC-IGS foram seqüenciadas neste estudo estão em negrito. A árvore foi enraizada usando a região do PC-IGS do plastídio de $A$. neglectum como um grupo externo. Valores superiores à 50\% na reamostragem de 1000 árvores são indicados nos clados (Felsenstein, 1985). 


\section{A.}

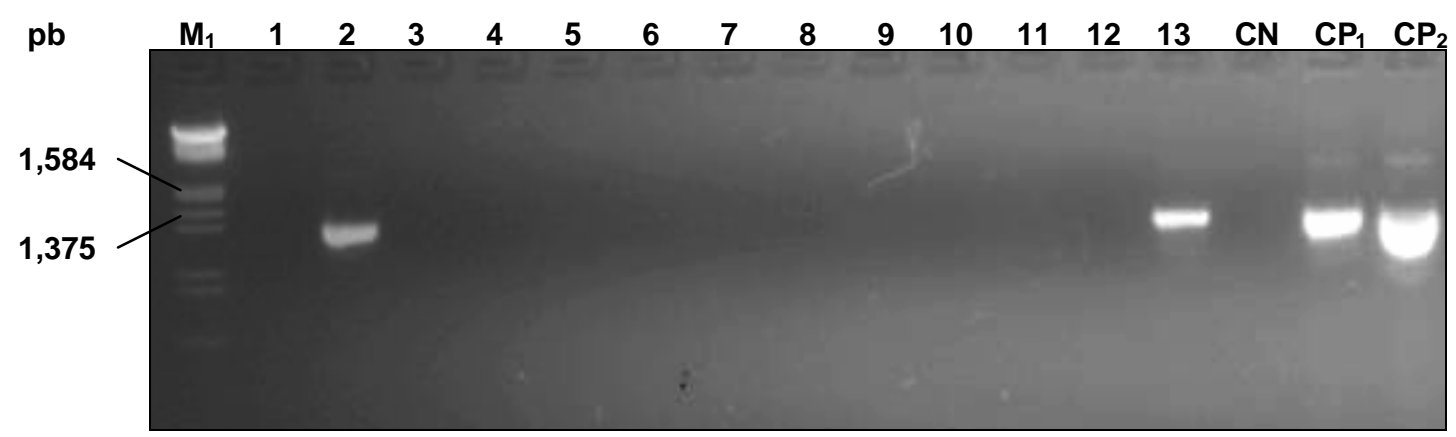

B.

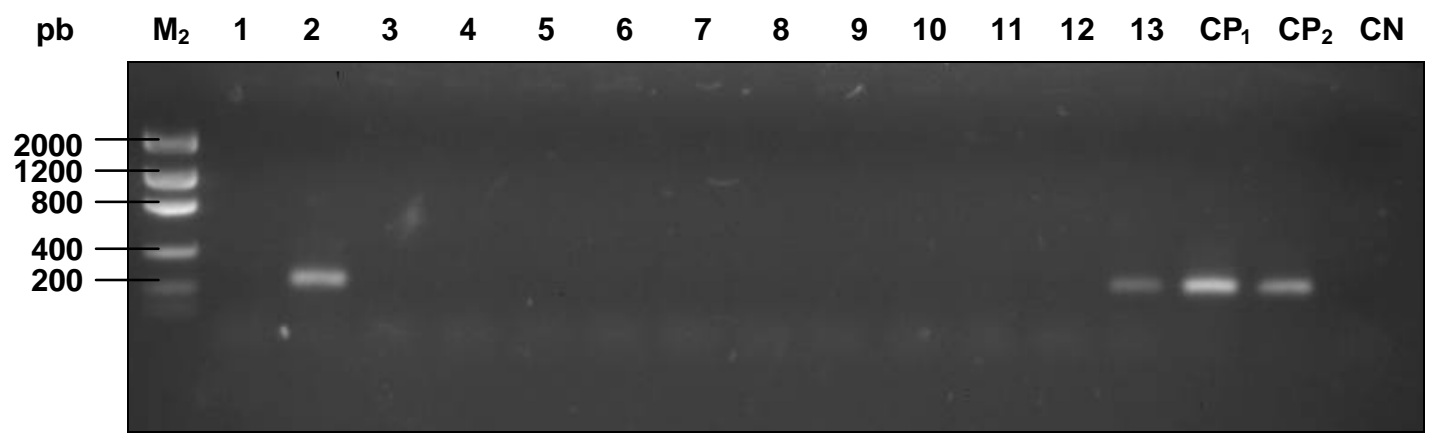

Figura 17 - Produtos de amplificação de fragmentos do gene mcyA. A. Oligonucleotídeos iniciadores MSF/MSR; B. Oligonucleotídeos iniciadores OMETF/OMETR. $M_{1}$ marcador molecular lambda DNA/ECoR I + Hind III; $\mathrm{M}_{2}$ - marcador molecular Low DNA Mass Ladder; 1 - Microcystis novacekii SPC503; 2 - Microcystis aeruginosa SPC777; 3 - Microcystis sp. SPC822; 4 - Sphaerocavum brasiliense SPC484; 5 Pseudanabaena galeata SPC772; 6 - Pseudanabaena mucicola SPC782; 7 Geitlerinema splendidum SPC923; 8 - Phormidium sp. SPC767; 9 - Rhabdoderma cocoide SPC766; 10 - Cylindrospermopsis raciborskii 339-T3; 11 - Raphidiopsis brookii 338-T2; 12 - Planktothrix sp. NPRG1; 13 - Microcystis protocystis SPC697; $\mathrm{CP}_{1}$ - controle positivo: Microcystis aeruginosa NPJB1; $\mathrm{CP}_{2}$ - controle positivo: Microcystis panniformis SPC702; CN - controle negativo (sem DNA). 
SPC702 $\left(\mathrm{CP}_{2}\right)$, as quais produzem microcistinas, segundo análises realizadas anteriormente em cromatografia líquida de alta performance (HPLC) e bioensaio, respectivamente, por outros autores (Azevedo et al., 1994; R. Ronda \& M.T.P. Azevedo, comunicação pessoal). Dentre as culturas testadas, as espécies de Microcystis aeruginosa SPC777, isolada da represa Billings, e Microcystis protocystis SPC697, isolada do reservatório Guarapiranga, apresentaram amplificações de seqüência do gene mcyA (Figura 17A) e podem, portanto, ser consideradas potencialmente tóxicas.

O mcyA é um dos genes envolvidos na biossíntese da microcistina e codifica para uma enzima de sintetase de peptídeo, que é essencial para a produção desta toxina (Tillett et al., 2000). Tillet et al. (2001) desenvolveram o conjunto de oligonucleotídeos iniciadores MSF/MSR, tendo como alvo o domínio único da NMT dessa enzima, capaz de identificar linhagens e/ou florações de cianobactérias potencialmente produtoras de microcistinas. Essa abordagem molecular para identificar cianobactérias e ou florações tóxicas pode ser mais vantajosa que as técnicas convencionais utilizadas no momento, ou seja, contagem de células em microscópio ótico e testes biológicos, bioquímicos ou químicos, pois é rápida e sensível.

A amplificação por PCR de genes envolvidos na biossíntese de toxinas não significa necessariamente que estes genes estão sendo expressos nas células. Assim, maiores informações (testes biológicos, bioquímicos ou químicos) são requeridas para se certificar de que sempre quando o gene está presente, ele está sendo expresso. Até o presente momento, os poucos trabalhos publicados sobre PCR específico para detecção de microcistinas, mostraram que em espécies de cianobactérias onde os genes essenciais envolvidos na biossíntese destas são detectados, eles também estão sendo expressos nas células (Baker et al., 2001, 2002; Bittencourt-Oliveira, 2003; Kurmayer et al., 2002, 2003; Neilan et al., 1999; Tillett et al., 2001). Os resultados obtidos para as espécies M. aeruginosa NPJB1 e M. panniformis SPC702 também estão de acordo com dados desses trabalhos.

Dessa forma, a técnica de PCR, usando iniciadores que tenham como alvo seqüências de genes essenciais para a biossíntese de microcistinas, tem sido capaz de distinguir linhagens de cianobactérias produtoras e não produtoras de microcistinas. Essa ferramenta, portanto, pode ser bastante útil, uma vez que é sabido que linhagens 
de uma mesma espécie de cianobactéria embora morfologicamente idênticas, podem apresentare diferenças quanto à toxicidade, como no caso de Microcystis aeruginosa, que possui linhagens tóxicas e não tóxicas (Meissner et al., 1996).

O conjunto de iniciadores MSF/MSR amplifica a seqüência completa do domínio da NMT do mcyA de 1300 pb, o que limita sua aplicação, como por exemplo, na técnica de DGGE. Assim, foram desenhados os iniciadores OMETF/OMETR que amplifica uma seqüência menor da região mais variável da NMT do mcyA visando, além da utilização na técnica de DGGE, facilitar o seu sequenciamento. Esses novos iniciadores amplificam seqüências de 200 pares de bases, conforme pode ser observado na Figura 17B. As espécies de cianobactérias que apresentaram amplificações usando esse conjunto de oligonucleotídeos iniciadores também produziram amplicons com os iniciadores MSF/MSR, ou seja, M. aeruginosa NPJB1, M. panniformis SPC702, M. aeruginosa SPC777 e M. protocystis SPC697.

Baker et al (2001), utilizando oligonucleotídeos iniciadores que amplificam regiões dos genes $m c y A$ e $m c y$, demonstraram que cianobactérias tóxicas e não tóxicas podem ser rapidamente identificadas em amostras ambientais sem a necessidade de serem isoladas e cultivadas. Duas florações de Microcystis, MD-1 e MD34, encontradas na represa de Malpas, na Austrália, foram testadas quanto a toxicidade. Os resultados obtidos mostraram dois genótipos distintos, tóxico e não tóxico, ocorrendo nesse local. MD-1 mostrou-se tóxica, apresentado amplicons para ambos os conjuntos de iniciadores utilizados, da mesma forma que $M$. aeruginosa 7806, usada como controle positivo.

Baseando-se na informação de seqüências dos genes mcy de Anabaena e Planktothrix, Hisbergues et al (2003) desenvolveram um conjunto de iniciadores que amplifica um fragmento do gene mcyA. Linhagens produtoras de microcistinas dos gêneros Anabaena, Microcystis e Planktothrix foram identificadas com esses iniciadores. Os amplicons resultantes foram também analisados por RFLP, produzindo fragmentos específicos para os diferentes gêneros. Os mesmos autores sugerem a utilização dessa abordagem para amostras ambientais, visto que permite a identificação de alguns dos gêneros produtores da toxina microcistina. 
A vantagem do método de PCR específico desenvolvido neste trabalho, assim como no de Hisbergues et al (2003), em relação aos demais publicados na literatura está no tamanho da seqüência amplificada (aproximadamente 200 pb). Embora mais linhagens de cianobactérias necessitem ser testadas para comprovar a eficiência desses iniciadores quanto à detecção de todas as isoformas de microcistinas existentes, os resultados obtidos até o momento possibilitam indicá-los para utilização, como por exemplo, na técnica de DGGE (eletroforese em gel desnaturante).

Genes funcionais, presentes em uma população bacteriana particular, podem ser usados como marcadores moleculares visando identificar determinados grupos de organismos e inferir relações filogenéticas entre eles (Wawer et al., 1997). O gene funcional $m c y A$, apresenta variação na sua seqüência de acordo com as linhagens de cianobactérias, que potencializa a sua utilização para detecção de espécies/linhagens tóxicas e não tóxicas (Neilan et al., 1999). Os iniciadores OMETF/OMETR também têm potencial para identificar gêneros, espécies e/ou linhagens de cianobactérias tóxicas e quem sabe para diferenciar as várias isoformas de microcistinas. Entretanto, mais dados são necessários para confirmar essas capacidades.

O sequenciamento do mcyA usando os iniciadores OMETF/OMETR foi realizada para as culturas Microcystis aeruginosa NPJB1, Microcystis panniformis SPC702, Microcystis aeruginosa SPC777 (represa Billings) e Microcystis protocystis SPC697 (represa Guarapiranga). As seqüências geradas foram comparadas através da análise BLAST. M. aeruginosa NPJB1, M. panniformis SPC702 e M. protocystis SPC697, apresentaram 99\%, 100\% e 100\% de identidade com M. aeruginosa UWOCCE7 (AF139341) respectivamente, enquanto que M. aeruginosa SPC777 apresentou $99 \%$ de similaridade com Microcystis sp. UWOCCAK(GV-) (AF139348). O número de seqüências analisadas neste estudo ainda é pequeno para fazer inferências quanto à capacidade desses iniciadores de diferenciar isoformas de microcistinas. Se a alta porcentagem de identidade mostrada entre essas seqüências indica que essas linhagens produzem a mesma isoforma microcistina, só poderá ser comprovada analisando-se a estrutura das toxinas produzidas. Entretanto, esses iniciadores parecem ter identificado linhagens tóxicas e não tóxicas. 
As relações filogenéticas entre as seqüências do mcyA foram analisadas através da construção de uma árvore filogenética usando também algumas outras seqüências de cianobactérias retiradas do GenBank ( $M$. aeruginosa UWOCCE7 - AF139341; Anabaena sp. 90 - AJ536156; Planktothrix agardhii - AJ441056; M. aeruginosa PCC7806 - AF139342; M. aeruginosa UWOCC017 - AF139331; M. aeruginosa UWOCC001 - AF139330; M. aeruginosa UWOCC019 - AF139332; M. aeruginosa UWOCC023 - AF139333; M. aeruginosa UWOCCCBS - AF139344; M. aeruginosa UWOCCMR-D - AF139340; M. aeruginosa UWOCCMR-C - AF139339; M. aeruginosa UWOCCMR-B - AF139338; M. aeruginosa UWOCCMR-A - AF139337; Microcystis sp. UWOCCBauldE - AF139346; M. aeruginosa UV027 - AF458094; M. aeruginosa PCC7820 - AF139343; Microcystis sp. UWOCCF - AF139345; Microcystis sp. UWOCCAK(GV-) AF139348; Microcystis sp. UWOCCAK-1 - AF139347; M. aeruginosa UWOCCS-15-b AF139336; M. aeruginosa UWOCC 84/1 - AF139334; M. aeruginosa UWOCCRID-1 AF139335).

A Figura 18, mostra as distâncias genéticas calculadas a partir do alinhamento das seqüências do mcyA de aproximadamente 200 pb. Enquanto M. aeruginosa NPJB1, M. panniformis SPC702 e M. protocystis SPC697 apresentaram relações de parentesco muito próximas com M. aeruginosa UWOCCE7, conforme pode ser verificado na árvore filogenética da Figura 18, estando também de acordo com os valores de identidades entre elas obtidos, M. aeruginosa SPC777, cuja identidade com Microcystis sp. UWOCC AK(GV-) foi de $99 \%$, aparece agrupada em um clado a parte. Interessante notar que foi possível alinhar as seqüências mcyA de outros gêneros de cianobactérias (Planktothrix, Anabaena). A porcentagem de identidade das seqüências de $M$. protocystis SPC697, M. panniformis SPC702, M. aeruginosa NPJB1 e M. aeruginosa SPC777 com as seqüências de Anabaena sp. 90 variou de 86 a $87 \%$ e com as de Planktothrix agardhii variou de 83 a $85 \%$.

A rápida análise da ocorrência natural de certos grupos de cianobactérias em águas é importante para monitorar a presença de espécies produtoras de toxinas e também para classificação biológica da qualidade da água. O monitoramento de organismos relevantes e suas toxinas, entretanto, utilizando as técnicas atuais de contagem de células e identificação usando microscopia ótica e testes biológicos, 
ESCALA 0.1

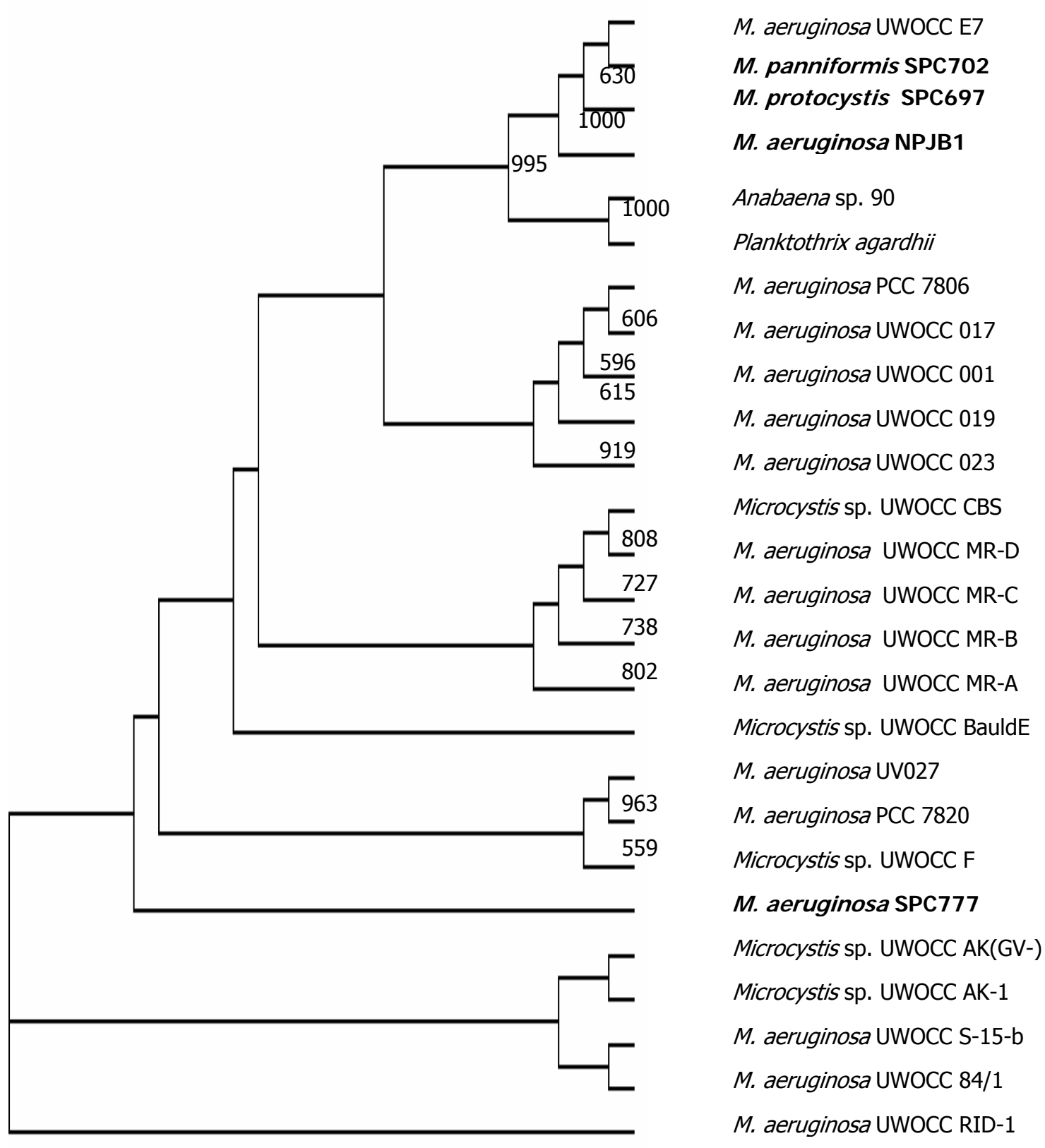

Figura 18 - Relações filogenéticas entre seqüências do domínio NMT do gene mcyA de cianobactérias. Organismos cujos fragmentos do gene foram seqüenciados neste estudo estão em negrito. Valores superiores à 50\% na reamostragem de 1000 árvores são indicados nos clados (Felsenstein, 1985). 
bioquímicos ou químicos é bastante trabalhoso, exige pessoal especializado e demanda tempo. Os dados apresentados neste estudo reforçam a possibilidade de utilização de oligonucleotídeos iniciadores específicos para a detecção de cianobactérias potencialmente produtoras de microcistinas, tomando-se por base as seqüências dos genes envolvidos em sua biossíntese. Essa metodologia é considerada rápida e sensível. Testes para a detecção do gene mcyA em amostras ambientais usando os iniciadores desenvolvidos neste estudo são necessários para realmente se comprovar a eficiência destes e para que, futuramente, um kit possa vir a ser desenvolvido e possivelmente utilizado como uma nova ferramenta para complementar o monitoramento das represas Billings e Guarapiranga e de outras represas. 


\section{CONCLUSÕES}

As cianobactérias estavam presentes em todas as amostras de água coletadas nas represas Billings e Guarapiranga e analisadas por DGGE usando os iniciadores específicos CYA359F/CYA781R. Espécies dos gêneros de Microcystis, Geitlerinema e Synechococcus puderam ser identificadas através desta técnica molecular. Entretanto, os resultados dos perfis das bandas obtidas no gel de DGGE tanto para culturas puras de cianobactérias como para amostras ambientais, mostraram que alguns cuidados essenciais são necessários para a utilização desta técnica em estudos de ecologia microbiana. A escolha do gene e dos oligonucleotídeos iniciadores são fundamentais para o sucesso na obtenção de bons resultados. Faz-se necessário o conhecimento prévio do número de cópias do gene presente nos genomas do grupo de bactérias a ser estudadas e iniciadores degenerados podem ser melhores, acessando um maior número de organismos em se tratando de amostras ambientais.

Durante 0 desenvolvimento deste estudo vários problemas relacionados principalmente com o uso de oligonucleotídeos iniciadores de seqüências do gene de rRNA $16 S$ de cianobactérias foram constatados, tanto na DGGE quanto na construção de mini-bibliotecas. Iniciadores usados de forma específica para o grupo das cianobactérias e publicados em revistas científicas, podem deixar de ser específicos à medida que seqüências antes desconhecidas são depositadas em bancos de dados públicos. Esse fato, expõe a problemática dos desenhos de iniciadores específicos, ficando claro durante a construção da mini-biblioteca de amplicons do gene de rRNA 16S, onde dois clones dela retirados não apresentaram identidade com o grupo de cianobactérias. Entretanto, os iniciadores da região do espaço intergênico do gene da ficocianina mostraram-se bem específicos e permitiram detectar a presença de várias 
linhagens de Microcystis e um outro gênero de cianobactéria, possivelmente uma Anabaena, em uma amostra de água coletada na represa Billings.

A análise completa da diversidade de cianobactérias nos locais amostrados ficou de uma certa forma comprometida, uma vez que não foram sequenciadas todas as bandas mostradas na DGGE e nem feitas mini-bibliotecas para todas as amostras de água coletadas. Entretanto, algumas cianobactérias presentes nas amostras ambientais foram identificadas através dos métodos moleculares utilizados.

Seqüência do gene mcyA foram isoladas, clonadas e sequenciadas com sucesso em quatro culturas puras de cianobactérias $(M$. aeruginosa NPJB1, $M$. panniformis SPC702, M. aeruginosa SPC777 e M. protocystis SPC697), usando os iniciadores OMETF/OMETR desenhados. Esse resultado mostra o potencial desses iniciadores para detectar cianobactérias produtoras de microcistina. Essa técnica uma vez bem estabelecida para organismos isolados, poderá proporcionar base suficiente para uma melhor deteç̧ão de comunidades aquáticas de cianobactérias potencialmente produtoras de microcistina em ambientes naturais. 


\section{REFERÊNCI AS BI BLI OGRÁFI CAS}

ALLEN, M.B. Simple conditions for growth of unicellular blue-green algae on plates. Journal of Phycology, v.4, p.1-4, 1968.

ALTSCHUL, S.F.; GISH, W.; MILLER, W.; MYERS, E.W.; LIPMAN, D.J. Basic local alignment search tool. J ournal of Molecular Biology, v.215, p.403-410, 1990.

AMANN, R.I.; LUDWIG, W.; SCHLEIFER, K.H. Phylogenetic identification and in situ detection of individual microbial cells without cultivation. Microbiology Reviews, v.59, n.1, p.143-169, 1995.

AMANN, R.I.; LUDWIG, W. Ribosomal RNA-targeted nucleic acid probes for studies in microbial ecology. Microbiology Reviews, v.24, p.555-565, 2000.

ANN, J.; CARMICHAEL, W.W. Use of a colorimetric protein phosphatase inhibition assay and enzyme linked inmuno sorbent assay for the study of microcystins and nodularins. Toxicon, v.32, p.1495-1507, 1994.

APT, K.E.; GROSSMAN, A.R. Characterization and transcript analysis of the major phycobiliprotein subunit genes from Aglaothamnion neglectum (Rhodophyta). Plant Molecular Biology, v.21, p.27-38, 1993.

APT, K.E.; COLLIER, J.L.; GROSSMAN, A.R. Evolution of the phycobiliproteins. J ournal of Molecular Biology, v.248, p.79-96, 1995.

ARMENT, A.R.; CARMICHAEL, W.W. Evidence that microcystin is athiotemplate product. J ournal of Phycology, v.32, p.591-597, 1995.

ASH, C.; MACKINTOSH, C.; MACKINTOSH, R.; FRICKER, C.R. Use of a protein phosphatase inhibition test for the detection of cyanobacterial toxins in water. Water Science and Technology, v.31, n.5/6, p.51-53, 1995.

AZEVEDO, S.M.F.O.; EVANS, W.R.; CARMICHAEL, W.W.; NAMIKOSHI, M. First report of microcystins from a Brazilian isolate of the cyanobacterium Microcystis aeruginosa. J ournal of Applied Phycology, v.6, p.261-265, 1994.

BAKER, J.A.; NEILAN, B.A.; ENTSCH, B.; MCKAY, D.B. Identification of cyanobacteria and their toxigenicity in environmental samples by rapid molecular analysis. Environmental Toxicology, v.16, n.6, p.472-482, 2001. 
BAKER, J.A.; ENTSCH, B.; NEILAN, B.A.; MCKAY, D.B. Monitoring changing toxigenicity of a cyanobacterial bloom by molecular methods. Applied and Environmental Microbiology, v.68, n.12, p.6070-6076, 2002.

BECKER, S.; FAHRBACH, M.; BÖGER, P.; ERNEST, A. Quantitative tracing, by Taq nuclease assays, of a Synecchococcus ecotype in a highly diversified natural population. Applied and Environmental Microbiology, v.68, p.4486-4494, 2002.

BERGMAN, B.; GALLON, J.R.; RAI, A.N.; STAL, L.J. N-fixation by non-heterocystous cyanobacteria. FEMS Microbiology Reviews, v.19, p.139-185, 1997.

BERGSLAND, K.J.; HASELKORN, R. Evolutionary relationship among eubacteria, cyanobacteria, and chloroplasts: evidence from the rpoCl gene of Anabaena sp. Strain PCC 7120. J ournal of Bacteriology, v.173, p.3446-3455, 1991.

BIRNBOIM, H.C.; DOLY, J. A rapid alkaline extraction procedure for screening recombinant plasmid DNA. Nucleic Acids Research, v.7, p.1513-1518, 1979.

BITTENCOURT-OLIVEIRA, M.C.; OLIVEIRA, M.C.; BOLCH, C.J.S. Genetic variability of Brazilian strains of the Microcystis aeruginosa complex (Cyanophyceae/ Cyanobacteria) using the phycocyanin intergenic spacer and flaking regions. Journal of Phycology, v.37, p.810-818, 2001.

BITTENCOURT-OLIVEIRA, M.C. Detection of potencial microcystin-producing cyanobacteria in Brazilian reservoirs with a mcyB molecular marker. Harmful Algae, p.51-60, 2003.

BOLCH, C.J.S.; BLAEKBURN, S.I.; NEILAN, B.A.; GREWE, P.M. Genetic characterization of strains of cyanobacteria using PCR-RFLP of the cpcBA Intergenic Spacer and flanking regions. J ournal of Phycology, v.32, p.445-451, 1996.

BOLCH, C.J.S.; BLACKBURN, S.; JONES, G.H.; ORR, P.T.; GREWE, P.M. Plasmid content and distribution in the toxic cyanobacterial genus Microcystis Kützing ex Lemmermann (Cyanobacteria: Chroococcales). Phycologia, v.36, p.6-11, 1997.

BONEN, L.; DOOLITTLE, W.F. On the prokaryotic nature of red algal chloroplasts. Proceedings of the National Academy of Sciences of the USA, v.72, p.23102314, 1975.

BONEN, L.; DOOLITTLE, W.F. Partial sequences of 16S rRNA and the phylogeny of blue-green algae and chloroplasts. Nature, v.261, p.669-673, 1976.

BONEN, L.; DOOLITTLE, W.F. Ribosomal RNA homologies and the evolution of the filamentous blue-green bacteria. Journal of Molecular Evolution, v.10, p.283291, 1978. 
BONEN, L.; DOOLITTLE, W.F.; FOX, G.E. Cyanobacterial evolution: results of $16 \mathrm{~S}$ ribosomal ribonucleic acid sequence analyses. Canadian Journal of Biochemistry, v.57, p.879-888, 1979.

BOON, N.; MARLÉ, C.; TOP, E.M.; VERSTRAETE, W. Comparison of the spatial homogeneity of physico-chemical parameters and bacterial 16S rRNA genes in sediment samples from a dumping site for dredging sludge. Applied Microbiology Biotechnology, v.53, p.742-747, 2000.

BOUVY, M.; MOLICA, R.; OLIVEIRA, S.; MARINHO, M.; BEKER, B. Dynamics of a toxic cyanobacterial bloom (Cylindrospermopsis racioborski) in a shallow reservoir in the semi-arid region of northeast Brazil. Aquatic Microbial Ecology, v.20, p.285-297, 1999.

BOUVY, M.; FALCAO, D.; MARINHO, M.; PAGANO, M.; MOURA, A. Occurrence of Cylindrospermopsis (Cyanobacteria) in 39 Brazilian tropical reservoirs during the 1988 drought. Aquatic Microbial Ecology, v.23, p.13-27, 2000.

BRANCO, C.W.; SENNA, P.A.C. Factors influencing the development of Cylindrospermopsis raciborskii and Microcystis aeruginosa in the Paranoá Reservoir, Brasília, Brazil. Archiv fur Hydrobiologie, v.75, p.85-96, 1994. Supplement, 105.

BRASIL. Ministério da Saúde/FUNASA. Normas de qualidade de água para consumo humano. Portaria N 1469 de 29 de dezembro de 2000. Brasília, 2000.

BRESLAUER, K.J.; FRANK, R.; BLOCKER, H.; MARKY, L.A. Predicting DNA duplex stability from the base sequence. Proceedings of the National Academy of Sciences of the USA, v.19, p.3746-3750, 1986.

BROCK, T.D.; MADINGAN, M.T. Biology of microorganisms. New Jersey: PrenticeHall, 1988.

BRYANT, D.A. Phycoerythrocyanin and phycoerythrin: properties and occurrence in cyanobacteria. J ournal of General Microbiology, v.128, p.835-844, 1982.

CANNEL, R.J.P. Algae as a source of biologically active products. Pesticide Science, v.39, p.147-153, 1993.

CARMICHAEL, W.W. Toxins of fresh water algae. In: TU, A.T. (Ed.) Handbook of natural toxins. New York: Marcel Dekker, 1988. p.121-147.

CARMICHAEL, W.W. Cyanobacteia secondary metabolites - The Cyanotoxins. Journal of Applied Bacteriology, v.72, p.445-459, 1992.

CARMICHAEL, W.W. The toxins of cyanobacteria. Scientific American, v.270, n.1, p.78-86, 1994. 
CARMICHAEL, W.W.; BENT, P.E. Hemagglutination method for detection of freshwater cyanobaceria (blue-green algae) toxins. Applied and Environmental Microbiology, v.41, n.6, p.1383-1388, 1981.

CASTENHOLZ, R.W. Ecology of blue-green algae in hot springs. In: CARR, N.G.; WHITTON, B.A. (Ed.) The biology of blue-green algae. Oxford: Blackwell Scientific Publication, 1973. p.379-414.

CASTENHOLZ, R.W.; WATERBURY, J.B. Cianobactéria. In: STALEY, J.T.; BRYANT, M.P.; PFENNING, N.; HOLT, J.G. (Ed.) Bergey's manual of systematic bacteriology. Baltimore: William and Wilkins, 1989. p.1710-1799.

CHEN, G.; YU, G.; WEI, G. Studies on microcystin contents in different drinking water in highly endemic area of liver cancer. Chung Hua Yu Fang I Hsueh Tsa Chih, v.30, n.1, p.6-9, 1996.

CHEN, X.; WIDGER, W.R. Physical genome map of the unicellular cyanobacterium Synechococcus sp. strain PCC 7002. Journal of Bacteriology, v.175, p.51065116, 1993.

CHRISTIANSEN, G.; FASTNER, J.; ERHARD, M.; BORNER, T.; DITTMANN, E. Microcystin biosynthesis in Planktothrix. genes, evolution, and manipulation. Journal of Bacteriology, v.185, n.2, p.564-572, 2003.

CHORUS, I.; MUR, L. Preventative measures. In: CHORUS, I.; BARTRAM, J. (Ed.) Toxic cyanobacteria in water: a guide to their public health consequences, monitoring and management. London: E \& FN Spon, 1999. p.235-273.

CHU, F.S.; HUANG, X.; WEI, R.D.; CARMICHAEL, W.W. Production and characterization of antibodies against microcystins. Applied and Environmental Microbiology, v.55, n.8, p.1928-1933, 1989.

CHU, F.S.; HUANG, X.; WEI, R.D. Enzyme-linked immunosorbent assay for microcystin in blue-green algal blooms. Journal of the AOAC, v.73, n.3, p.451-456, 1990.

COHEN Y.; JORGENSEN, B.B.; REVSBECH, N.P.; PAPLAWSKI, R. Adaptation to hydrogen sulfide of oxygenic and anoxygenic photosynthesis among cyanobacteria. Applied and Environmental Microbiology, v.51, p.398-407, 1986.

COMPANHIA DE TECNOLOGIA DE SANEAMENTO AMBIENTAL. Relatório de qualidade das águas interiores do estado de São Paulo. São Paulo: CETESB, 2003. (Série Relatórios).

COSTA, S.M.; AZEVEDO, S.M.F.O. Implantação de um Banco de Culturas de Cianofíceas Tóxicas. I heringia. Série Botânica, v.45, p.69-74, 1994. 
CURY, J.C. Atividade microbiana e diversidades metabólica e genética em solos de mangue contaminado com petróleo. Piracicaba, 2002. 84p. Dissertação (Mestrado) - Escola Superior de Agricultura "Luiz de Queiroz", Universidade de São Paulo.

DICKMAN, M.; HAN, X. Paleopigment evidence of competition between phytoplankton and a cyanobacterial algal mat in a meromictic lake near Toronto, Ontario Canada. Hydrobiologia, v.306, p.131-146, 1995.

DITTMANN, E.; NEILAN, B.A.; ERHARD, M.; VON DÖHREN, H.; BÖRNER, T. I nsertional mutagenesis of a peptide synthetase gene which is responsible for hepatotoxin production in the cyanobacterium Microcystis PCC7806. Molecular Microbiology, v.26, p.779-787, 1997.

DOMINGOS, P.; RUBIN, T.K.; MOLICA, R.J .R.; AZEVEDO, S.M.F.O.; CARMICHAEL, W.W. First report of microcystin production by picoplanktonic cyanobacteria isolated from a northeast Brazilian drinking water supply. Environmental Toxicology, v.14, p.31-35, 1999.

DONNER, G.; SCHWARZ, K.; HOPPE, H.G.; MUYZER, G. Profiling the succession of bacterial populations in pelagic chemoclines. Archives of Hydrobiology, v.48, p.7-14, 1996.

DOR, I.; DANIN, A. Cyanobacterial desert crusts in the Dead Sea Valley, Israel. Archiv fur Hydrobiologie, v.83, p.197-206, 1996. Supplement, 117.

EICHNER, C.A.; ERB, R.W.; TIMMIS, K.N.; WAGNER-DOBLER, I. Thermal gradient gel electrophoresis analysis of bioprotection from pollutant shocks in the activated sludge microbial community. Applied and Environmental Microbiology, v.65, p102-109, 1999.

EL FANTROUSSI, S.; VERSCHUERE, L.; VERSTRAETE, W.; TOP, E.M. Effect of phenylurea herbicides on soil microbial communities estimated by analysis of $16 \mathrm{~S}$ rRNA gene fingerprints and community-level physiological profiles. Applied and Environmental Microbiology, v.65, p.982-988, 1999.

ERNEST, A. Cyanobacterial picoplankton from Lake Constance. I. Isolation by fluorescence characteristics. Journal of Plankton Research, v.13, p.1307-1312, 1991.

EWING, B.; GREEN, P. Base-calling of automated sequencer traces using phred. II. Error probabilities. Genome Research, v.8, p.186-194, 1998. 
EWING, B.; HILLIER, L.; WENDL. M.C.; GREEN, P. Base-calling of automated sequencer traces using phred. I. Accuracy assessment. Genome Research, v.8, p.175-185, 1998.

FALCONER, I.R. Health implications of Cyanobacterial (blue-green algae) toxins. In: INTERNATIONAL WORKSHOP ON TOXIC CYANOBACTERIA CURRENT STATUS OF RESEARCH AND MANAGEMENT, Adelaide, 1994. Proceedings. Adelaide, 1994.

FAY, P. Oxygen relations of nitrogen fixation in cyanobacteria. Microbiology Reviews, v.56, p.340-373, 1992.

FERGUSSON, K.M.; SAINT, P.C. Multiplex PCR assay for Cylindrospermopsis raciborskii and cylindrospermopsin-producing cyanobacteria. Environmental Toxicology, v.18, n.2, p.120-125, 2003.

FERRIS, M.J.; WARD, D.M. Seasonal distributions mat examined by denaturing gradient gel electrophoresis. Applied and Environmental Microbiology, v.63, p.1375-1381, 1997.

FERRIS, M.J.; NOLD, S.C.; REVSBECH, N.B.; WARD, D.M. Population structure and physiological changes within a hot spring microbial mat community flowing disturbance. Applied and Environmental Microbiology, v.63, p.1367-1374, 1997.

FIORE, M.F.; MOON, D.H.; TSAI, S.M.; LEE, H.; TREVORS, J.T. Miniprep DNA isolation from unicellular and filamentous cyanobacteria. Journal of Microbiological Methods, v.39, p.159-169, 2000.

FISCHER, W.J.; DIETRICH, D.R. Toxicity of the cyanobacterial cyclic heptapeptide toxins microcystin-LR and $-R R$ in early life stages of the African clawed frog (Xenopus laevis). Aquatic Toxicology, v.49, p.189-198, 2000.

GARCIA-PICHEL, F.; LOPEZ-CORTES, A.; NÜBEL, U. Phylogenetic and morphological diversity of cyanobacteria in soil desert crusts from the Colorado plateau. Applied and Environmental Microbiology, v.67, n.4, p.1902-1910, 2001

GIOVANNONI, S.J.; TURNER, S.; OLSEN, G.J.; BARNS, S.; LANE, D.J.; PACE, N.R. Evolutionary relationships among cyanobacteria and green chloroplasts. J ournal of Bacteriology, v.170, p.3584-3592, 1988.

GLAZER, N.A. Light guides. Directional energy transfer in a photosynthetic antenna. J ournal of Biological Chemistry, v.264, p.1-4, 1989.

GORDON, D.; ABAJIAN, C.; GREEN, P. Consed: a graphical tool for sequence finishing. Genome Research, v.8, p.195-202, 1998. 
GORHAM, P.R.; MCLACHLAN, J.R.; HAMMER, V.T.; KIM, W.K. I solation and culture of toxic strains of Anabaena flos-aquae (Lyngb.) Breb. Verhandlungen I nternationale Vereinigung fur Theoretische und Angewandte Limnologie, v.15, p.796-804, 1964.

HALL, T. BioEdit - version 5.0.6. Raleigh: North Carolina State University, Department of Microbiology, 2001. 192p.

HARADA, K.; KONDO, F.; LAWTON, L. Laboratory analysis of cyanotoxins. In: CHORUS, I.; BARTRAM, J. (ED.) Toxic cyanobacteria in water: a guide to their public health consequences, monitoring and management. London: E \& FN Spon, 1999. p.369-399.

HEUER, H.; SMALLA, K. Application of denaturing gradient gel electrophoresis and temperature gradient gel electrophoresis for studying soil microbial communities. In: ELSAS, J.D. van; TREVORS, J.T.; WELLINGTON, E.M.H. (Ed.) Modern soil microbiology. New York: Marcel Dekker, 1997. p.353-373.

HISBERGUES, M.; CHRISTIANSEN, G.; ROUHIAINEN, L.; SIVONEN, K.; BÖRNER, T. PCR-based identification of microcistin-producing genotypes of different cyanobacterial genera. Archives of microbiology, v.180, n.6, p.402-410, 2003.

HONKANEN, R.E.; ZWILLERS, J.; MOORE, R.A.; DAILY, S.L.; KHATRA, B.S.; DUKELOW, M.; BOYNTON, A.L. Characterization of microcystin-LR, a potent inhibitor of type 1 and $2 \mathrm{~A}$ protein phosphatases. Journal of Biological Chemistry, v.265, n.19, p.19401-19404, 1990.

JACKSON, C.R.; RODEN, E.E.; CHURCHILL, P.F. Denaturing gradient gel electrophoresis can fail to separate 16S rDNA fragments with multiple base differences. Molecular Biology Today, v.1, p.49-51, 2000.

JANSE, I.; MEIMA, M.; KARDINAAL, W.E.A.; ZWART, G. High-resolution differentiation of cyanobacteria by using rRNA-Internal Transcribed Spacer Denaturing Gradient Gel Electrophoresis. Applied and Environmental Microbiology, v.69, n.11, p.6634-6643, 2003.

JOCHIMSEN, E.M.; CARMICHAEL, W.W.; AN, J. et al. Liver failure and death after exposure to microcystins at a hemodialysis center in Brazil. New England J ournal of Medicine, v.338, p.873-878, 1998.

KANEKO, T.; MATSUBAYASHI, T.; SUGITA M.; SUGIURA, M. Physical and gene maps of the unicellular cyanobacterium Synechococcus sp. strain PCC6301 genome. Plant Molecular Biology, v.3, p.193-201, 1996a.

KANEKO, T.; SATO, S.; KOTANI, $H$. et al. Sequence analysis of the genome of the unicellular cyanobacterium Synechocystis sp. strain PCC6803. II. Sequence 
determination of the entire genome and assignment of potential protein-coding regions. DNA Research, v.3, p.109-136, 1996b.

KELLY, K.M.; CHISTOSERDOV, A.Y. Phylogenetic analysis of the succession of bacterial communities in the Great South Bay (Long I sland). FEMS Microbiology Ecology, v.35, n.1, p.85-95, 2001.

KERKHOF, L.; SPECK, M. Ribosomal RNA gene dosage in marine bacteria. Molecular Marine Biology and Biotechnology, v.6, n.3, p.260-267, 1997.

KOMÁREK, J.; ANAGNOSTIDIS, K. Modern approach to the classification system of cyanophytes 4 - Nostocales. Archiv fur Hydrobiologie, v.56, p.247-354, 1989. Supplement, 823.

KOMÁREK, J.; KOMÁRKOVÁ-LEGNEROVÁ, J.; SANT'ANNA, C.L.; AZEVEDO, M.T.P.; SENNA, P.A.C. Two common Microcystis species (Chroococcales, Cyanobacteria) from tropical America, including M. panniformis sp. nov. Cryptogamie/ Algologie, v.23, n.2, p.159-177, 2002.

KÓS, P.; GORZO, G.; SURANYI, G.; BORBELY, G. Simple and efficient method for isolation and measurement of cyanobacterial hepatotoxins by plant tests (Sinapis alba L.) Analytical Biochemistry, v.225, p.49-53, 1995.

KREITLOW, S.; MUNDT, S.; LINDEQUIST, U. Cyanobacteria - a potential source of new biologically active substances. Journal of Biotechnology, v.70, p.61-63, 1999.

KURMAYER, R.; DITTMANN, E.; FASTNER, J.; CHORUS, I. Diversity of microcystin genes within a population of the toxic cyanobacterium Microcystis spp. in lake Wannsee (Berlin, Germany). Microbial Ecology, v.43, p.107-118, 2002.

KURMAYER, R.; CHRISTIANSEN, G.; CHORUS, I. The abundance of microcystinproducing genotypes correlates positively with colony size in Microcystis sp. and determines its microcystin net production in lake Wannsee. Applied and Environmental Microbiology, v.69, n.2, p.787-795, 2003.

LAAMANEN, M.J.; FORSSTRÖM, L.; SIVONEN, K. Diversity of Aphanizomenon flosaquae (cyanobacterium) populations along a Baltic Sea salinity gradient. Applied and Environmental Microbiology, v.68, p.5296-5303, 2002.

LAGOS, N.; ONODERA, H.; ZAGATTO, P.A.; ANDRINOLO, D.; AZEVEDO, S.M.F.O.; OSHIMA, Y. First evidence of paralytic shellfish toxins in the freshwater cyanobacterium Cylindrospermopsis raciborskii, isolated from Brazil. Toxicon, v.37, p.1359-1373, 1999. 
LAMBERT, T.W.; HOLMES, C.F.B.; HRUDEY, S.E. Adsorption of microcystin-LR by activated carbon and removal in full scale water treatment. Water Research, v.30, n.6, p.1411-1422, 1996.

LANE, D.L.; PACE, B.; OISEN, G.J.; STAHL, D.A.; SOGIN, M.L.; PACE, N.R. Rapid determination of $16 \mathrm{~S}$ ribosomal RNA sequences for phylogenetic analyses. Proceedings of the National Academy of Sciences of the USA, v.82, p.69556959, 1985.

LOPEZ-CORTES, A.; GARCIA-PICHEL, F.; NÜBEL, U.; VAZQUEZ-JUAREZ, R. Cyanobacterial diversity in extreme environments in Baja California, Mexico: a polyphasic study. International Microbiology, v.4, n.4, p.227-236, 2001.

LUDWIG，W.; STRUNK， O.; KLUGBAUER, N.; WEIZENEGGER, M.; NEUMAIER, J.; BACHLEITNER, M.; SCHLEIFER, K.H. Bacterial phylogeny based on comparative sequence analysis. Electrophoresis, v.19, p.554-568, 1998.

MAcGREGOR, B.J. Molecular approaches to the study of aquatic microbial communities. Current Opinion in Biotechnology, v.10, p.220-224, 1999.

MACNAUGHTON, S.; STEPHEN, J.R.; CHANG, Y.J.; PEACOCK, A.; FLEMMING, C.A.; LEUNG, K.T.; WHITE, D.C. Characterization of metal-resistant soil eubacteria by polymerase chain reaction - denaturing gradient gel electrophoresis with isolation of resistant strains. Canadian J ournal of Microbiology, v.45, p.116-124, 1999.

MAIDAK, B.L.; COLE, J.R.; PARKER JUNIOR, C.T.; GARRITY, G.M.; LARSEN, N.; LI, B.; LIBURN, T.G.; MCCAUGHEY, M.J.; OLSEN, G.J.; OVERBEEK, R.; PRAMANIK, S.; SCHMIDT, T.M.; TIEDJE, J.M.; WOESE, C.R. A new version of the RDP (Ribosomal Database Project). Nucleic Acids Research, v.27, p.171-173, 1999.

MANN, N.H.; CARR N.G. Photosynthetic prokaryotes. Biotechnology handbooks. London: Plenum Press, 1992. v.6, 275p.

MCDERMOTT, C.M.; FEOLA, R.; PLUDE, J. Detection of cyanobacterial toxins (microcystins) in waters of northern Wisconsin by a new immunoassay technique. Toxicon, v.33, n.11, p.1433-1442, 1995.

MEISSNER, K.; DITTMAN, E.; BÕRNER, T. Toxic and non-toxic strains of the cyanobacterium Microcystis aeruginosa contain sequences homologous to peptide synthetase genes. FEMS Microbiology Letters, v.135, p.295-303, 1996.

MUR, L.R.; SKULBERG, O.M.; UTKILEN, H. Cyanobacteria in the environment. In: CHORUS, I.; BARTRAM, J. (Ed.) Toxic cyanobacteria in water: a guide to their public health consequences, monitoring and management. London: E \& FN Spon, 1999. p.15-37. 
MUYZER, G. Genetic fingerprinting of microbial communities - present status and future perspective. In: INTERNATIONAL SYMPOSIUM MICROBIAL ECOLOGY, 8., Halifax, 1999. Proceedings. 1999. http://plato.acadiau.ca/isme/Symposium16/muyzer.PDF (9 Marc. 2002).

MUYZER, G.; DE WAAL, E.C.; UITTERLINDEN, A.G. Profiling of complex microbial populations by denaturing gradient gel electrophoresis analysis of polymerase chain reaction-amplified genes coding for $16 \mathrm{~S}$ rRNA. Applied and Environmental Microbiology, v.59, p.695-700, 1993.

MUYZER, G.; SMALLA, K. Application of denaturing gradient gel electrophoresis (DGGE) and temperature gradient gel electrophoresis (TGGE) in microbial ecology. Antonie van Leeuwenhoek, v.73, p.127-141, 1998.

NEILAN, B.A.; COX, P.T.; HAWKINS, P.R.; GOODMAN, A.E. 165 ribosomal RNA gene sequence and phylogeny of toxic Microcystis sp. (cyanobacteria). DNA Sequence, v.4, p.333-337, 1994.

NEILAN, B.A.; JACOBS, D.; GOODMAN, A.E. Genetic diversity and phylogeny of toxic cyanobacteria determined by DNA polymorphisms within the phycocyanin locus. Applied and Environmental Microbiology, v.61, p.3875-3883, 1995.

NEILAN, B.A.; JACOBS, D.; DEL DOT, T.; BLACKALL, L.L.; HAWKINS, P.R.; COX, P.T.; GOODMAN, A.E. rRNA sequences and evolutionary relationships among toxic and nontoxic cyanobacteria of the genus Microcystis. International Journal of Systematic Bacteriology, v.47, p.693-697, 1997.

NEILAN, B.A.; DITTMANN, E.; ROUHIAINEN, L.; BASS, R.A.; SCHAUB, V.; SIVONEN, K.; BÖRNER, T. Nonribosomal peptide synthesis and toxigenicity of cyanobacteria. J ournal of Bacteriology, v.181, p.4089-4097, 1999.

NELISSEN, B.; WILMOTTE, A.; DE BAERE, R.; HAES, F.; VAN DE PEER, T.; NEEFS, J.M.; DE WACHTER, R. Phylogenetic study of cyanobacteria on the basis of $16 \mathrm{~S}$ ribosomal RNA sequences. Belgian J ournal of Botany, v.125, p.210-213, 1992.

NELISSEN, B.; WILMOTTE, A.; NEEFS, J.M.; DE WACHTER, R. Phylogenetic relationships among filamentous helical cyanobacteria investigated on the basis of $16 \mathrm{~S}$ ribosomal RNA gene sequence analysis. Systematic and Applied Microbiology, v.17, p.206-210, 1995a.

NELISSEN, B.; VAN DE PEER, T.; WILMOTTE, A.; DE WACHTER, R. An early origin of plastids within the cyanobacterial divergence is suggested by evolutionary trees based on complete 16S rRNA sequences. Molecular Biology and Evolution, v.12, p.1166-1173, 1995b. 
NELISSEN, B.; DE BAERE, R.; WILMOTTE, A.; DE WACHTER, R. Phylogenetic relationships of nonaxenic filamentous cyanobacterial strains based on 16S rRNA sequence analysis. Journal of Molecular Evolution, v.42, p.194-200, 1996.

NÜBEL, U.; ENGELEN, B.; FELSKE, A.; SNAIDR, J.; WIESHUBER, A.; AMANN, R.I.; LUDWIG, W.; BACKHAUS, H. Sequence heterogeneties of genes encoding $16 \mathrm{~S}$ rRNAs in Paenibacillus polymixa detected by temperature gradient gel electrophoresis. J ournal of Bacteriology, v.178, p.5636-5643, 1996.

NÜBEL, U.; GARCIA-PICHEL, F.; MUYZER, G. PCR primers to amplify $16 \mathrm{~S}$ rRNA genes from cyanobacteria. Applied and Environmental Microbiology, v.63, p.33273332, 1997.

NÜBEL, U.; GARCIA-PICHEL, F.; KUHL, M.; MUYZER, G. Quantifying microbial diversity: morphotypes, 16S rRNA genes, and carotenoides of oxygenic phototrophs in microbial mats. Applied and Environmental Microbiology, v.65, p.422-430, 1999.

OLIVER, R.L.; GANF, G.G. The optical-properties of a turbid reservoir and its phytoplankton in relation to photosynthesis and growth (mount-bold reservoir, south-Australia). J ournal of Plankton Research, v.10, p.1155-1177, 1988.

ØVREÅS, L.; FORNEY, L.; DAAE, F.L.; TORSVIK, V. Distribution of bacterioplankton in meromictic lake Saelenvannet, as determined by denaturing gradient gel electrophoresis of PCR-amplified gene fragments for 16S rDNA. Applied and Environmental Microbiology, v.63, p.3367-3373, 1997.

PACE, N.R. A molecular view of microbial diversity and the biosphere. Science, v.276, p.734-740, 1997.

PAGE, R.D.M. TreeView - version 1.6.6. Glasgow: University of Glasgow, 2001.

PALENIK, B. Polymerase evolution and organism evolution. Current Opinion in Genetics and Development, v.2, p. 931-936. 1992.

PALINSKA, K.A.; LIESACK, W.; RHIEL, E.; KRUMBEIN, W.E. Phenotype variability of identical genotypes: the need for a combined approach in cyanobacterial taxonomy demonstrated on Merismopedia-like isolates. Archives of Microbiology, v.166, p.224-233, 1996.

PIERCE, R.H.; KIRKPATRICK, G.J. Innovative techniques for harmful algal toxin analysis. Environmental Toxicology and Chemistry. v.20, n.1, p. 107-114, 2001.

RAI, A.N. CRC handbook of symbiotic cyanobacteria. Boca Raton: CRC Press, 1990. 253p. 
RAPALA, J.; SIVONEN, K.; LYRA, C.; NIEMELA, S.I. Variation of microcystins cyanobacterial hepatotoxins in Anabaena spp. as a function of growth stimuli. Applied and Environmental Microbiology, v.63, n.6, p.2206-2212, 1997.

RAPPE, M.S.; VERGIN, K.; GIOVANNONI, S.J. Phylogenetic comparisons of a coastal bacterioplankton community with its counterparts in open ocean and freshwater systems. FEMS Microbiology Ecology, v.33, n.3, p.219-232, 2000.

REYNOLDS, C.S.; JAWORSKI, G.H.M.; CMIECH, H.A.; LEEDALE, G.F. On the annual cycle of the blue-green alga Microcystis aeruginosa (Kütz. Emend. Elenkin.) Philosophical Transactions of the Royal Society of London. Serie B, v.293, p.419-477, 1980.

RIPPKA, R.; WATERBURY, J.B.; STANIER, R.Y. Isolation and purification of cyanobacteria: some general principles. In: STARR, M.P.; STOLP, H.; TRÜPER, H.G.; BALOWS, A.; SCHLEGEL, H.G. (Ed.) The prokaryotes. Berlin: Springer-Verlag, 1981. p.212-220.

ROSADO, A.S.; DUARTE, G.F.; SELDIN, L.; ELSAS, J.D. van. Quantitative 16S rDNAtargeted polymerase chain reaction and oligonucleotide hybridization for the detection of Paenibacillus azotofixans in soil and the wheat rhizosphere. FEMS Microbiology Ecology, v.19, p.153-164, 1996.

ROSADO, A.S.; DUARTE, G.F.; SELDIN, L.; ELSAS, J.D. van. Molecular microbial ecology: a minireview. Revista de Microbiologia, v.28, p.135-147, 1997.

ROSEMBAUM, V.; RIESNER, D. Temperature-gradient gel electrophoresis; termodynamic analyses of nucleic acids and proteins in purified form and in cellular extracts. Biophysical Chemistry, v.26, p.235-246, 1987.

SAITO, S.; NAKANO, Y.; KUSHIDA, M.; HARADA, K.; NAKANO, M. Cross-reactivity and neutralizing ability of monoclonal antibodies against microcystins. Microbiology and I mmunology, v.38, n.5, p.389-392, 1994.

SAITOU, N.; NEI, M. The neighbour-joining method: a new method for reconstructing phylogenetic trees. Molecular Biology and Evolution, v.4, p.406-425, 1987.

SAMBROOK, J.; FRITSCH, E.F.; MANIATIS, T. Molecular cloning: a laboratory manual. 2.ed. Cold Harbor: Cold Spring Harbor Laboratory Press, 1989.

SANT'ANNA, C.L.; AZEVEDO, M.T.P. Contribution to the knowledge of potentially toxic cyanobacteria from Brazil. Nova Hedwigia, v.71, p.359-385, 2000.

SCHEMBRI, M.A.; NEILAN, B.A.; SAINT, C.P. I dentification of genes implicated in toxin production in the cyanobacterium Cylindrospermopsis raciborskii. Environmental Toxicology, v.16, p.413-421, 2001. 
SIMPSON, J.M.; MCCRACKEN, V.J.; WHITE, B.A.; GASKINS, H.R.; MACKIE, R.I. Application of denaturant gradient gel electrophoresis for the analysis of the porcine gastrointestinal microbiota. Journal of Microbiological Methods, v.36, n.1, p.167-179, 1999.

SIVONEN, K. Cyanobacterial toxins and toxin production. Phycologia, v.35, n.6, p.12-24, 1996.

SIVONEN, K.; JONES, G. Cyanobacterial toxins. In: CHORUS, I.; BARTRAM, J. (Ed.) Toxic cyanobacteria in water: guide for their public health consequences, monitoring and management. London: E. \& F.N. Spon, 1999. p.41-111.

SKULBERG, O.M. Biophotolysis, hydrogen production and algal culture technology. In: YÜRÜM, Y. (Ed.) Hydrogen energy system. Production and utilization of hydrogen and future aspects. Dordrecht: Kluwer Academic Publishers, 1995. p.95110. (NATO ASI Series E - Applied Sciences, 295).

SKULBERG, O.M.; CODD, G.A.; CARMICHAEL, W.W. Toxic blue-green algae blooms in Europe: a growing problem. Ambio, v.13, p.244-247, 1984.

SMITH, A.J. Modes of cyanobacterial carbon metabolism. Annals of Microbiology, v.134B, p.93-113, 1983.

SOUZA, R.C.R.; CARVALHO, M.C.; TRUZII, A.C. Cylindrospermopsis raciborskii (Cyanophyceae) dominance and contribution to the knowledge to the Rio Pequeno Arm, Billings Reservoir, Brazil. Environmental Toxicology and Water Quality, v.13, p.73-81, 1988.

STACKEBRANDT, P.H.A.; GOEBEL, B.M. Taxonomic note: a place for DNA-DNA reassociation and 16S RNA sequence analysis in the present species definition in bacteriology. I nternational J ournal of Systematic Bacteriology, v. 44, p.846849, 1994.

STAL, L.J .; MOEZELAAR, R. Fermentation in cyanobacteria. FEMS Microbiology Reviews, v.21, p.179-211, 1997.

STANIER, R.Y.; COHEN-BAZIRE, G. Phototrophic prokaryotes: The cyanobacteria. Annual Review of Microbiology, v.31, p.225-274, 1977.

STREHL, B.; HOLTZENDORFF, J.; PARTENSKY, F.; HESS, W.R. A small and compact genome in the marine cyanobacterium Prochlorococcus marinus CCMP 1375: lack of an intron in the gene for tRNA(Leu)(UAA) and a single copy of the rRNA operon. FEMS Microbiology Letters, v.181, p.261-6, 1999. 
SUZUKI, M.T.; BÉJÀ, O.; TAYLOR, T.; DeLONG, E.F. Phylogenetic analysis of ribosomal RNA operons from uncultivated coastal marine bacterioplancton. Applied and Environmental Microbiology, v.3, n.5, p.323-331, 2001.

SWOFFORD, D.; OLSEN, G.; WADDEL, P.; HILLIS, M. Phylogenetic inference. In: HILLIS, D.M.; MORTIZ, C.; MABLE, B.K. (Ed.) Molecular systematics. 2.ed. Sunderland, Massachusetts:Sinauer Assoc., 1996. p.407-514.

TESKE, A.; SIGALEVICH, P.; COHEN, Y.; MUYZER, G. Molecular identification of bacteria from a coculture by denaturing gradient gel electrophoresis of $16 \mathrm{~S}$ ribosomal DNA fragments as a tool for isolation in pure cultures. Applied and Environmental Microbiology, v.62, n.11, p.4210-4215, 1996.

THOMPSON, J.D.; HIGGINS, D.G.; GIBSON, T.J. CLUSTAL W: improving the sensitivity of progressive multiple sequence alignment through sequence weighting, positionspecific gap penalties and weigh matrix choice. Nucleic Acids Research, v.22, p.4673-4680, 1994.

TILLETT, D.; DITTMAN, E.; ERHARD, M.; VON DÖHREN, H.; BÖRNER, T.; NEILAN, B.A. Structural organization of microcystin biosynthesis in Microcystis aeruginosa PCC7806: an integrated peptide-polyketide synthetase system. Chemistry \& Biology, v.7, n.10, p.753-764, 2000.

TILLETT, D.; PARKER, D.L.; NEI LAN, B.A. Detection of toxigenicity by a probe for the microcystin synthetase A gene (mcyA) of the cyanobacterial genus Microcystis: comparison of toxicities with 16S rRNA and phycocyanin operon (Phycocyanin Intergenic Spacer) phylogenies. Applied and Environmental Microbiology, v.67, p.2810-2818, 2001.

TURNER, S. Molecular systematics of oxygenic photosynthetic bacteria. Plant Systematics and Evolution, v.11, p.13-52, 1997.

UENO, Y.; NAGATA, S.; TSUTSUMI, T.; HASEGAWA, A.; YOSHIDA, F.; SUTTAIT, M.; MEBS, D.; PUTSCH, M.; VASCONCELOS, V. Survey of microcystins in environmental water by a highly sensitive imunoassay based on monoclonal antibody. Natural Toxins, v.4, n.6, p.271-276, 1996.

VAITOMAA, J.; RANTALA, A.; HALINEN, K.; ROUHIAINEN, L.; TALLBERG, L.M.; SIVONEN, K. Quantitative Real-Time PCR for determination for microcystin synthetase E copy number for Microcystis and Anabaena in lakes. Applied and Environmental Microbiology, v.69, n.12, p.7289-7297, 2003.

VETRIANI, C.; JANNASCH, H.W.; MACGREGOR, B.J .; STAHL, D.A.; REYSENBACH, A.L. Population structure and phylogenetic characterization of marine benthic Archaea in deep-sea sediments. Applied and Environmental Microbiology, v.65, n.10, p.4375-4384, 1999. 
WARD, D.M.; WELLER, R.; BATESON, M.M. 16S RNAr sequences reveal numerous uncultured microorganisms in a natural community. Nature, v.345, p.63-65, 1990.

WAYNE, L.G.; BRENNER, D.J.; COLWELL, R.R. et al. International Committee on Systematic Bacteriology. Report of the ad hoc committee on reconciliation of approaches to bacterial systematics. International Journal of Systematic Bacteriology, v.37, p.463-464, 1987.

WAWER, C.; JETTEN, M.S.M.; MUYZER, G. Genetic diversity and expression of the [NiFe] hydrogenase large subunit gene of Desulfovibrio spp. in environmental samples. Applied and Environmental Microbiology, v.63, p.4360-4369, 1997.

WELLER, R.; WELLER, J.W.; WARD, D.M. $16 \mathrm{~S}$ rRNA sequences of uncultivated hot springs cyanobacterial mat inhabitants retrieved as randomly primed cDNA. Applied and Environmental Microbiology, v.57, p.1146-1151, 1991.

WHITTON, B. Cyanobacteria (Blue-Green Algae). In: HALL, G.S. (Ed.) Methods for the examination of organismal diversity in soil and sediments. Wallingford: CAB International, 1996. p.43-51.

WILMOTTE, A. Molecular evolution and taxonomy of the cyanobacteria. In: BRYANT, D.A. (Ed.) The molecular biology of cyanobacteria. Dordrecht: Kluwer, 1994. p.1-25.

WILMOTTE, A.; URNER, S.; VAN DE PEER, Y.; PACE, N.R. Taxonomic study of marine Oscillatoriacean strains (Cyanophyceae, Cyanobacteria) with narrow trichomes. II. Nucleotide sequence analysis of the $16 \mathrm{~S}$ ribosomal RNA. Journal of Phycology, v.28, p.828-838, 1992.

WILMOTTE, A.; VAN DER AUWERA, G.; DE WACHTER, R. Structure of the $16 \mathrm{~S}$ ribosomal RNA of the thermophilic cyanobacterium Chlorogloeopsis HTF ("Mastigocladus laminosus HTF") strain PCC7518 and phylogenetic analysis. FEBS Letters, v.317, p.96-100, 1993.

WILMOTTE, A.; NEEFS, J.M.; DE WACHTER, R. Evolutionary affiliation of the marine nitrogen-fixing cyanobacterium Trichodesmium sp. strain NIBB 1067, derived by $16 \mathrm{~S}$ ribosomal RNA sequence analysis. Microbiology, v.140, p.2159-2164, 1994.

WILSON, K.M.; SCHEMBRI, M.A.; BAKER, P.D.; SAINT, C.P. Molecular characterization of the toxic cyanobacterium Cylindrospermopsis raciborskii and design of a speciesspecific PCR. Applied and Environmental Microbiology, v.66, n.1, p.332-338, 2000.

WOESE, C.R. Bacterial evolution. Microbiology Reviews, v.51, p.221-271, 1987. 
WOESE, C.R.; SOGIN, M.L.; BONEN, L.; STAHL, D. Sequence studies on $16 \mathrm{~S}$ ribosomal RNA from blue-green alga. Journal of Molecular Evolution, v.4, p.307-315, 1975.

YACOBI, Y.Z.; POLLINGHER, U.; GONEN, Y.; GERHARDT, V.; SUKENINK, A. HPLC analysis of phytoplankton pigments from Lake Kinneret with special reference to the bloom-forming dinflagellate Peridinium gatunense (Odinophyceae) and chlorophyll degradation products. Journal of Plankton Research, v.18, n.10, p.1781-1796, 1996.

YUNES, J.S.; SALOMON, P.S.; MATTHIESEN, A.; BEATTIE, K.A.; RAGGET, S.L.; CODD, G.A. Toxic blooms of cyanobacteria in the Patos lagoon estuary, southern Brazil. J ournal of Aquatic Ecosystem Health, v.5, p.223-229, 1996. 